\title{
قياس الغائب على الشاهد \\ ودوره في تكوين العقل الاعتزالي
}

\section{د. حسن الحطظف*}

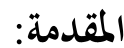

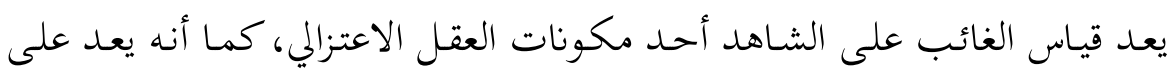

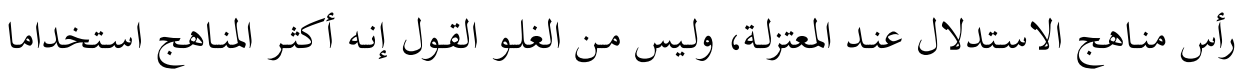

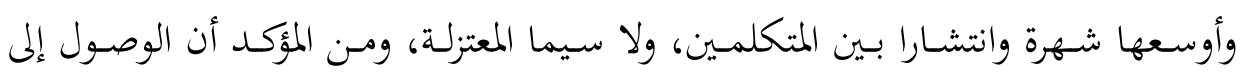

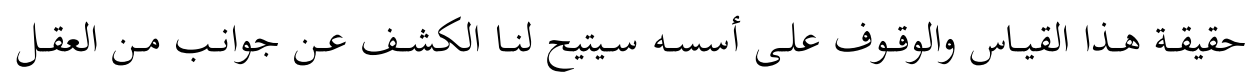

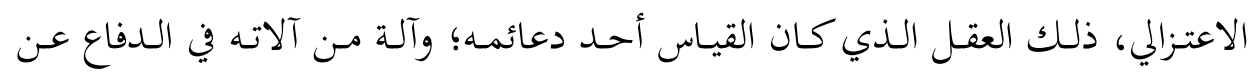

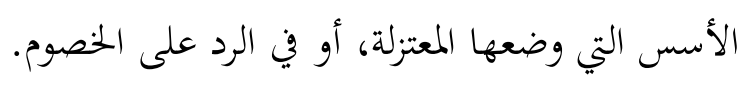

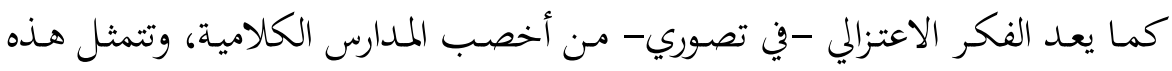

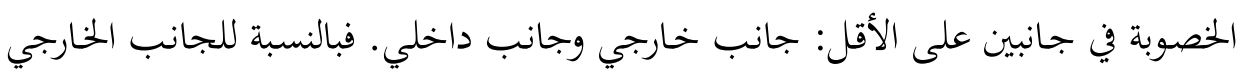

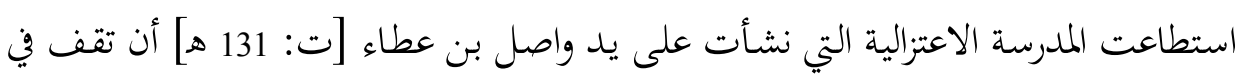

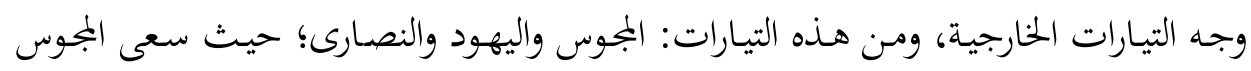

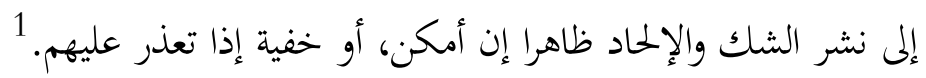

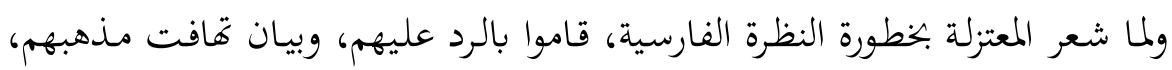
وممن رد على المجوس، واصل بـن عطاء [ت:131]2 مؤسس المعتزلة، وإبراهيم النظام

" باحث سوري، دكتور في قسم العقائد والأديان بكلية الشريعة، جامعة دمشق.

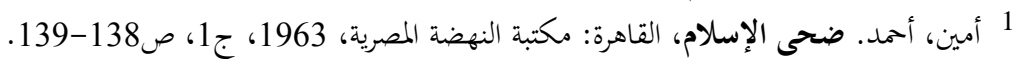
2 الشابي، علي. مباحث في علم الكلام والفلسفة، تونس: دار بو سلامة، 1977، 1963، ص31. 
[ت:231] الذي رد عليهم ردا قويا، وأبطل كثيرا مـ أفكارهم، ${ }^{3}$ والقاضي عبد الجبار

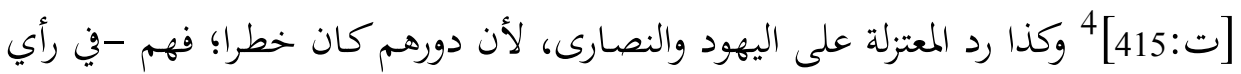

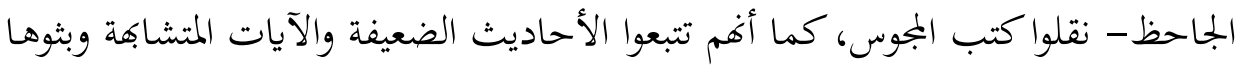
للعوام، يضاف إلى ذلك معرفتهم بأفكار الملحدين. 5

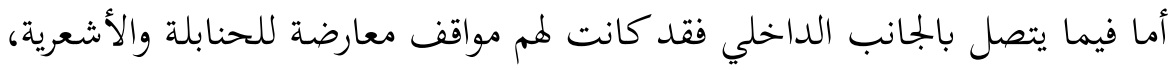

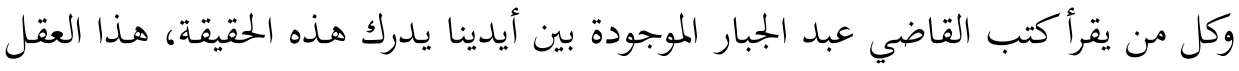

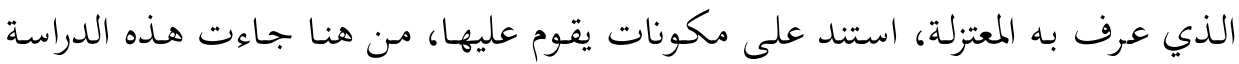

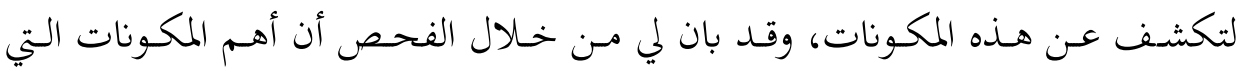

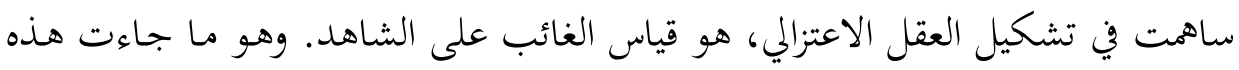
الدراسة لتكشف عنه وعن مدى قيمته العلمية.

وقد تناولت كثير من الدراسات هذا الجانب، ولكن بشكل عرضي، ولم أطلع

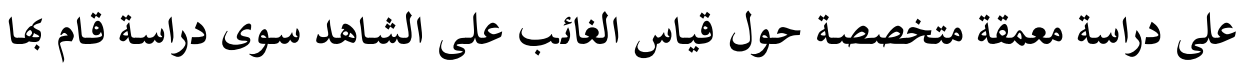

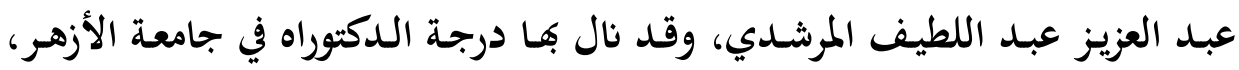

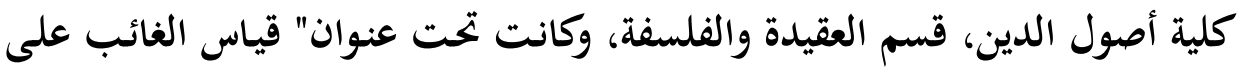

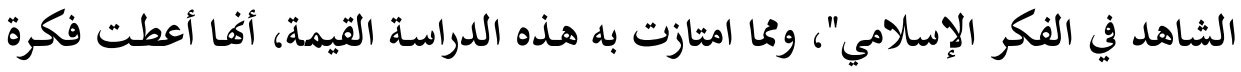

3 المصدر السابق، وانظر فتح الله، خليفة. محاضرات في الفلسفة الإسلامية، القاهرة: دار الجامعات المصرية، 1979،

4 الأسد آبادي، القاضي عبدالجبار بن أممد الممذاني . شرح الأصول الخمسة، القاهرة: مكتبة وهبة، 1996،

ص284-290.200.

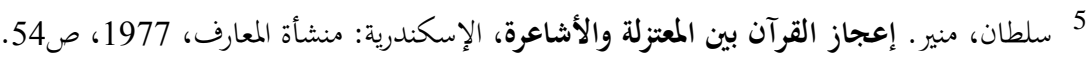

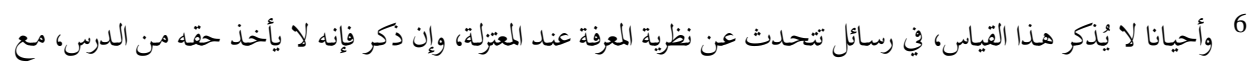

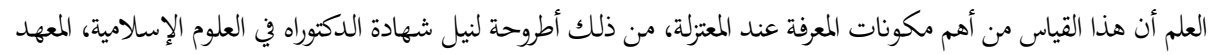

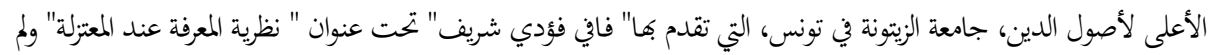

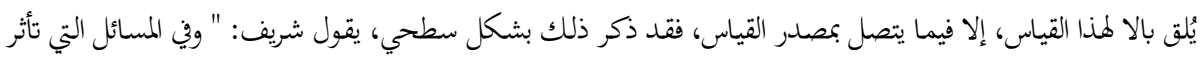

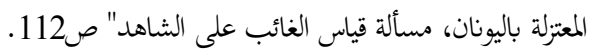

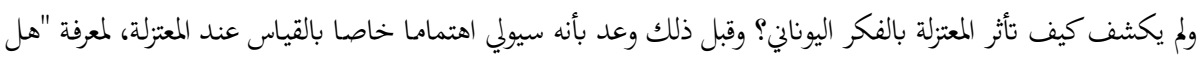

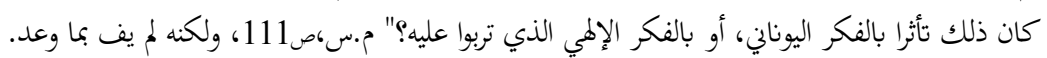


شمولية عن قياس الغائب على الثـاهد في الفكر الإسلامي، ولكنها -في تصوري-

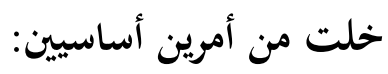

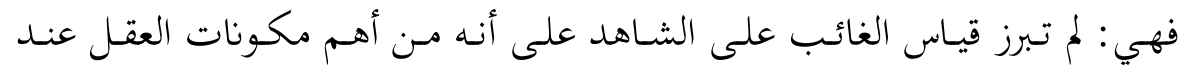

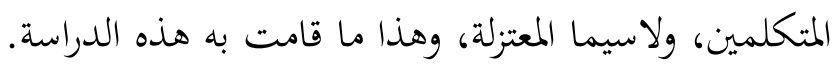

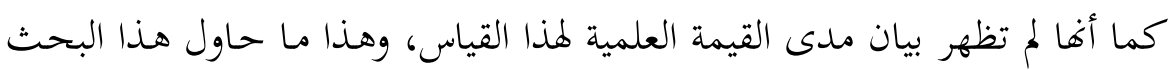

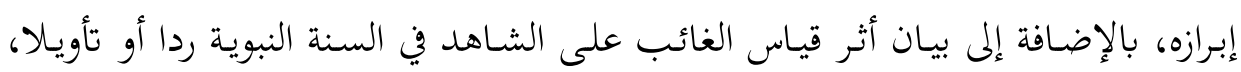
وهذه من أهم الإضافات التي جاءت بها هذه الدراسة.

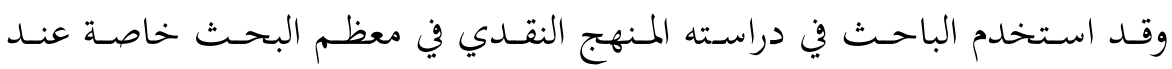

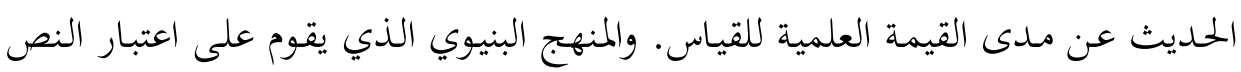

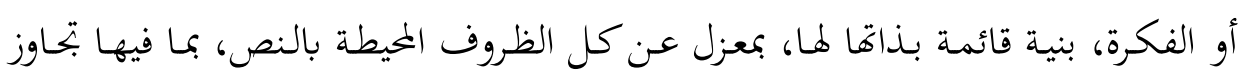

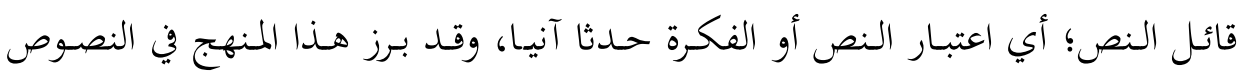

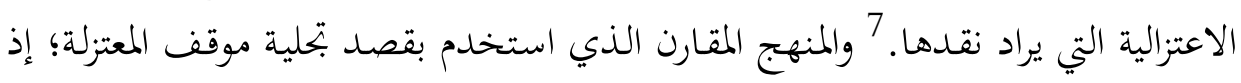

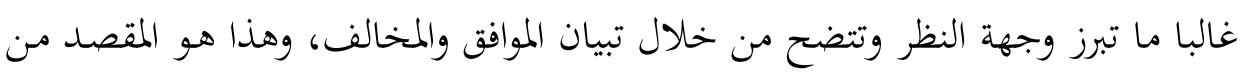

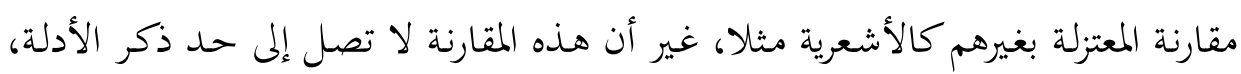
والدخول في التفاصيل الجزئية.

\section{أولا: تعريف قياس الغائب على الثاهد وأركانه}

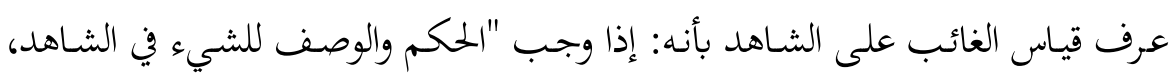

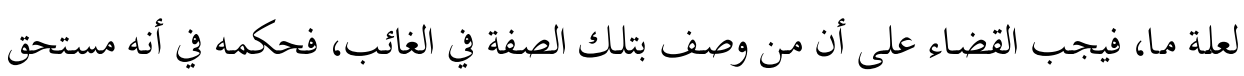
لتلك العلة، حكم مستحقها في الشاهد."

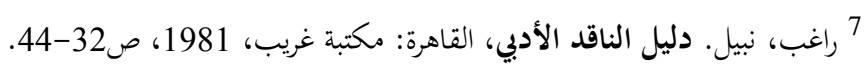

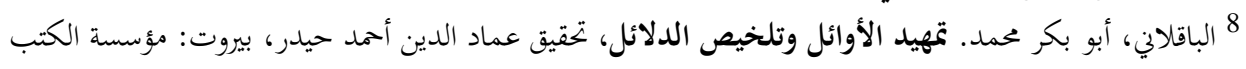

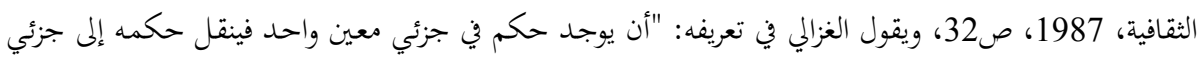


ويمكن أن نمثل لهذا القياس بإثبات صفة العلم لله عند المعتزلة من خلال الأفعال الإنسانية

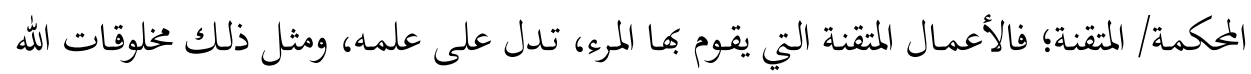

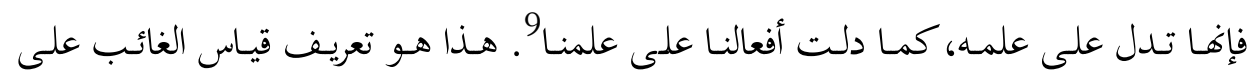

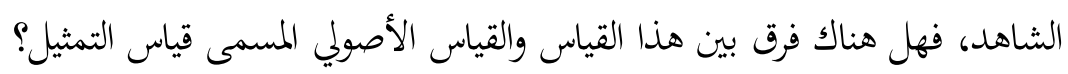
عنـد النظر في الجزئيـات الفقهيـة المستندة إلى القيـاس الأصسولي والجزئيـات الكلاميـة

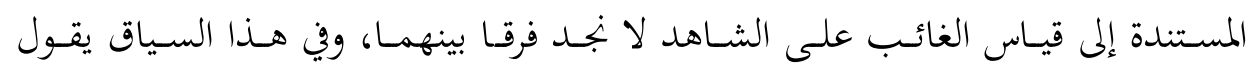
الغزالي: "التمثيل [أي قياس التمثيل] وهو الذي يسميه الفقهاء قياسا، ويسميه المتكلمون

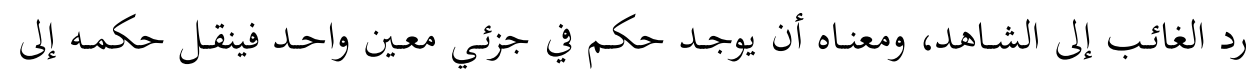
جزئي آخر يشابهه بوجه ما."

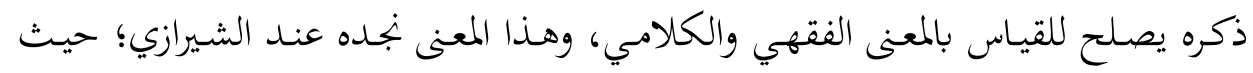
يعرف القياس بقوله: "اعلم أن القياس حمل فرع على أصل في بعض أحكامه بمعنى يجمع

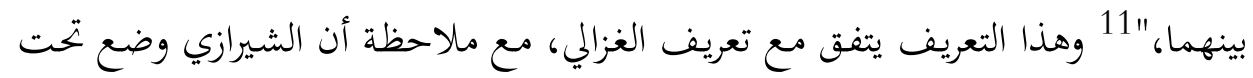
هذا التعريف القياس الفقهي وقياس الغائب على الشاهد. وسيتضح عدم الفرق بينهما من خلال البحث في أركان القياس الأربعة، وإذا كان تمة من فرق فهو في مجال استخدام كل منهما.

إذا، ليس هناك فرق بين قياس الغائب على الشاهد وقياس التمثيل، ولكن هل هناك

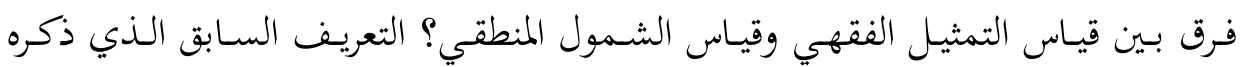

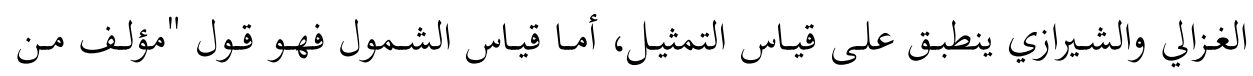

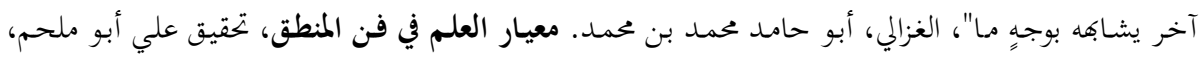

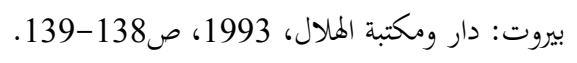

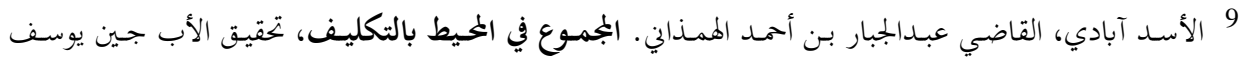

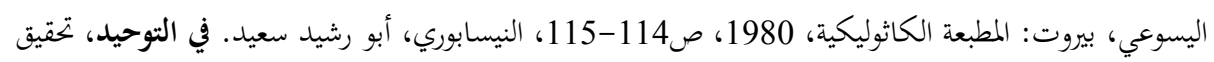

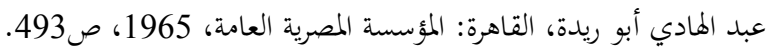

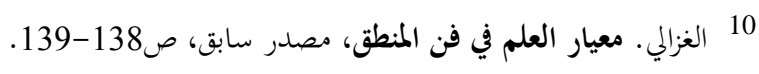

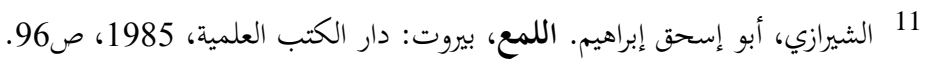


قضايا متى حصل التسليم بها لزم عنه لذاته قول آخر،"12 ومثال ذلك: كل الناس ميتون،

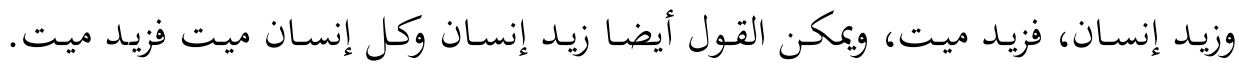

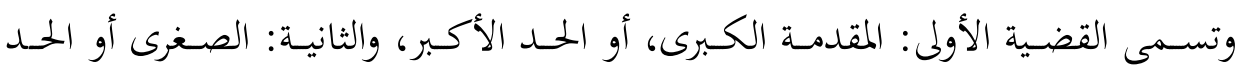
الأوسط باعتباره متكررا بين الأوسط والأكبر، والثالثة: النتيجة. 13 وقد ذكر ابن تيمية وجـه العلاقة بين قياس الشمول وقياس التمثيل، وخرج بنتيجة

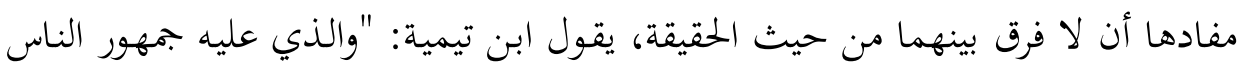

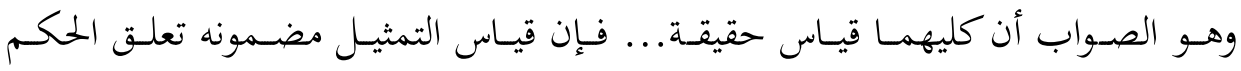

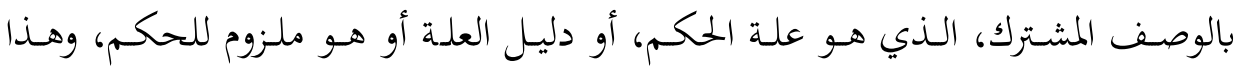

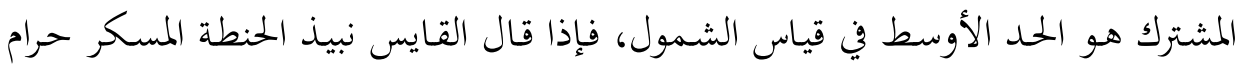

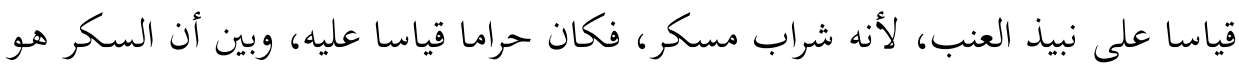

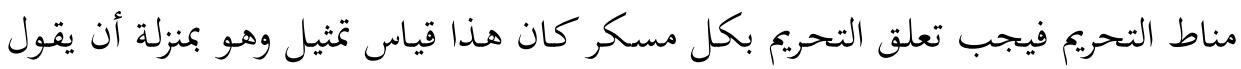

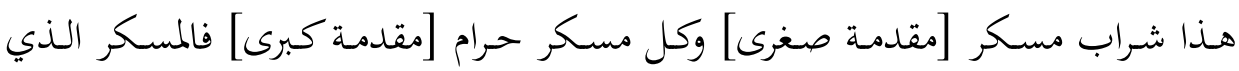
جعله في هذا القياس حدا أوسط، هو الذي جعله في ذلك القياس الجامع المشترك الذي مئري

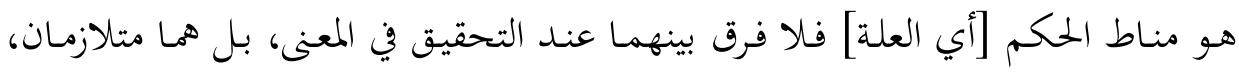

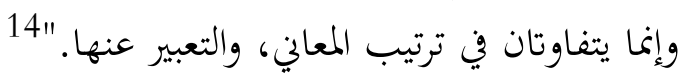
فمن الواضح أن لا فرق بينهما من حيث المضمون، ويبقى الفرق من حيث التعبير

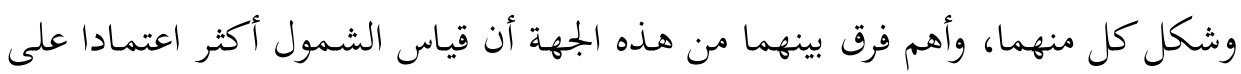

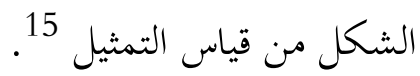

12 حبنكة، عبدالرحمن حسن. ضـوابط المعرفة، ط3، دمشق: دار القلم، 1988، ص228. وانظر: جليل الدين،

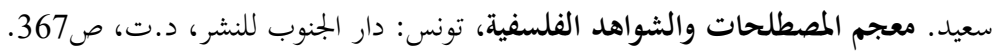

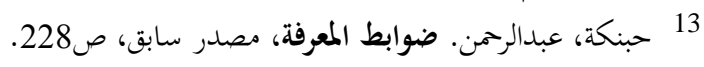

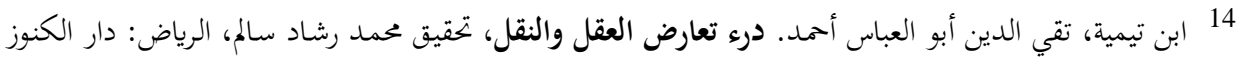

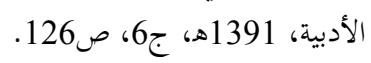
15 أحمد، عطا الله مختار محمود. "مناهج الاستدلالال لدى المتكلمين والفلاسفة المسلمين". (رسالة دكتوراه، كلية دار العلوم، جامعة القاهرة)، ص334. 
والناظر إلى التعريف السابق والمثال الذي ذكرناه لقياس الغائب على الشاهد يجد أنه

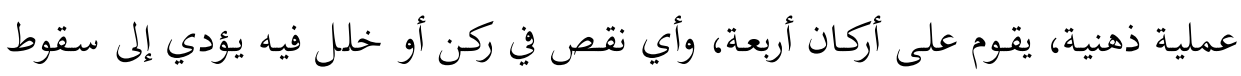

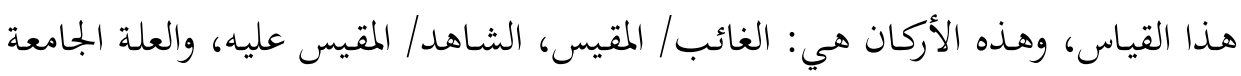
بين المقيس والمقيس عليه، والحكم. ويكمن أن نطبق المثال السابق على الأركان الأربعة:

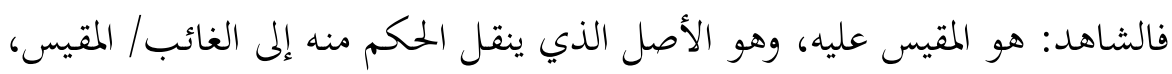

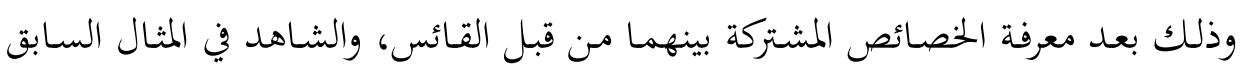

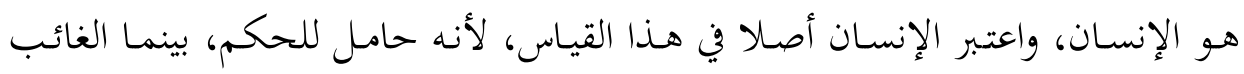

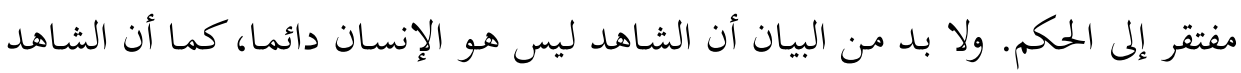

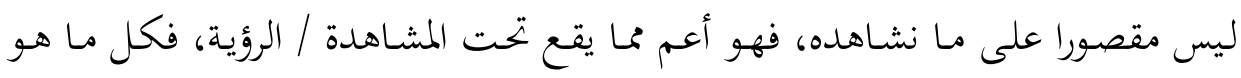

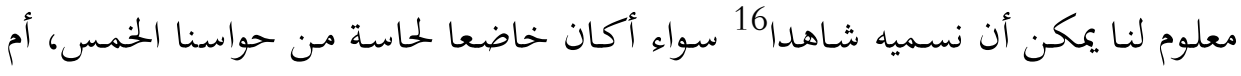

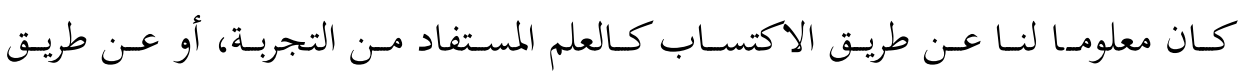
الاضطرار؛ كعلم الإنسان بما في نفسه.

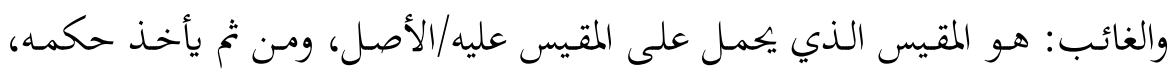

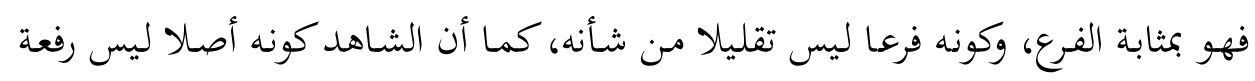

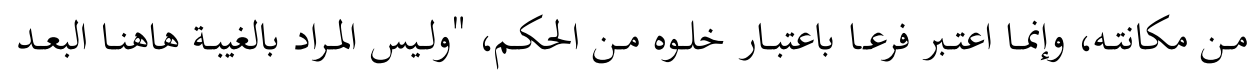

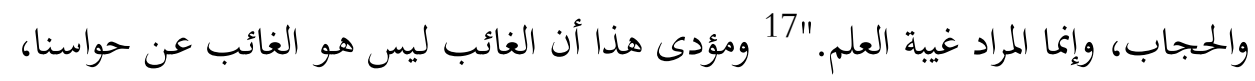

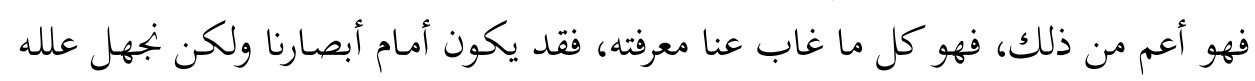

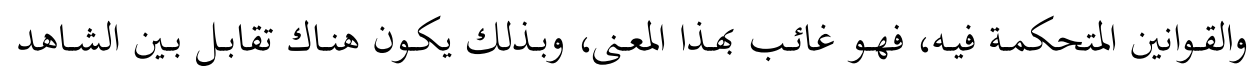

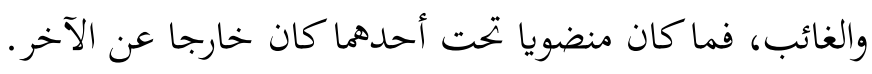

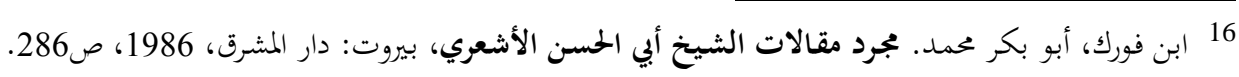

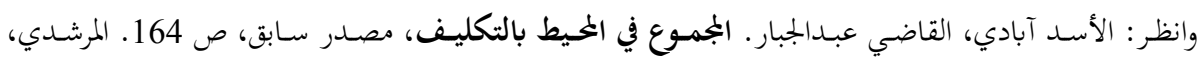

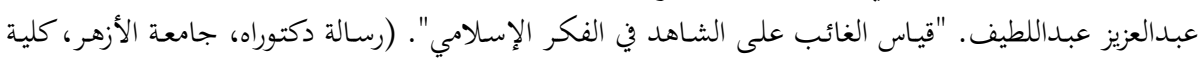

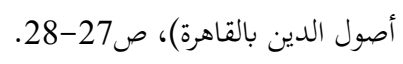
17 ابن فورك. مجرد مقالات الشيخ أبي الحسن الأشعري، مصدر سابق، ص286. 


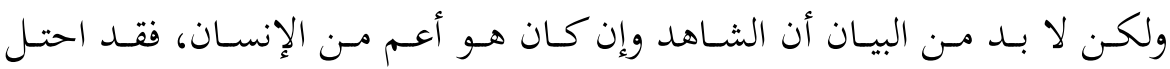

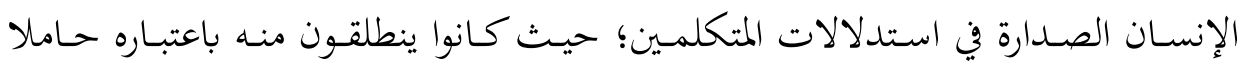

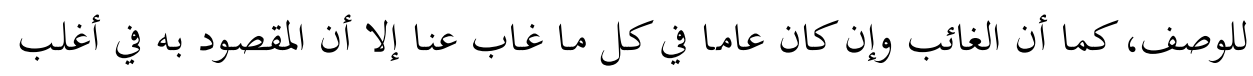
استدلالات المتكلمين هو الله. - المان. غير أن السؤال الذي يرد هنا، هل اختيار كلمة الشاهد كأصل والغائب كفرع جاء أنهاء

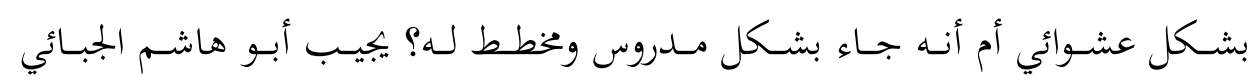

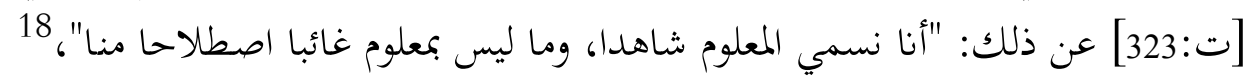

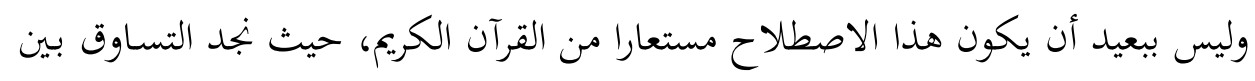

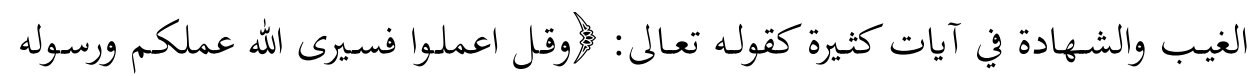

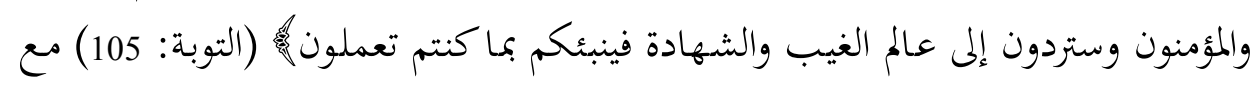

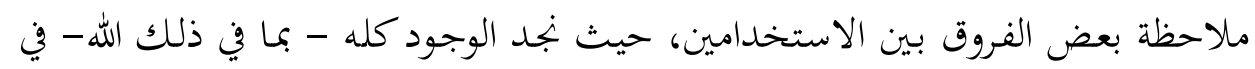

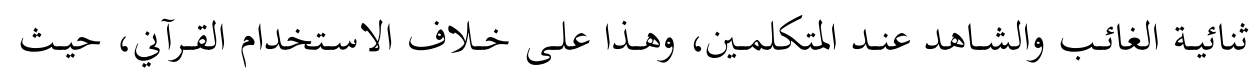

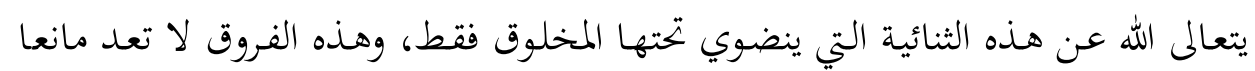

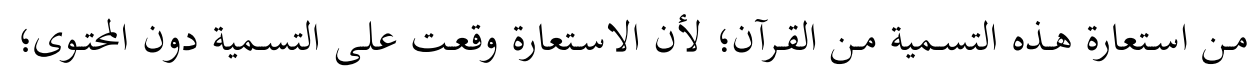

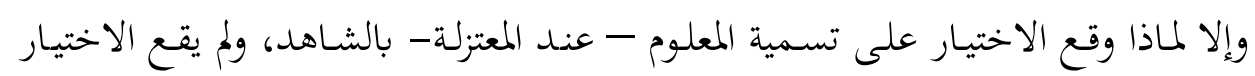

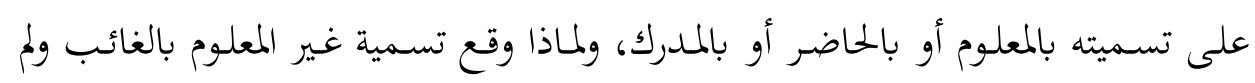

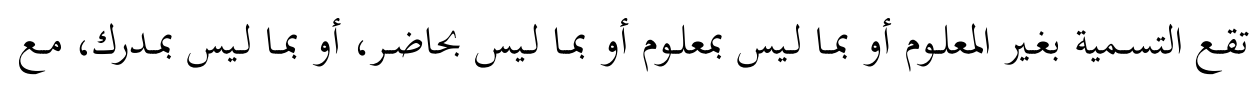

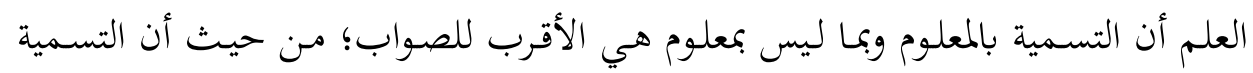

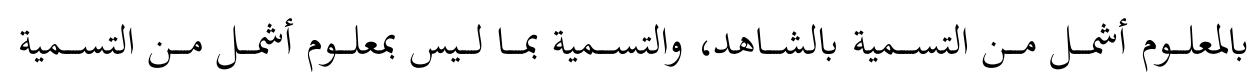
بالغائب.

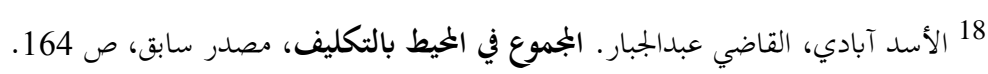

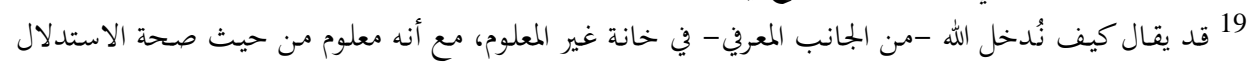

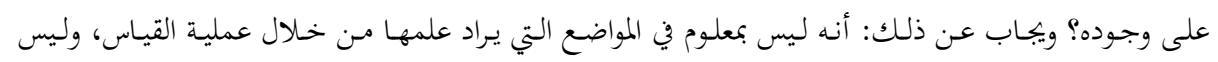

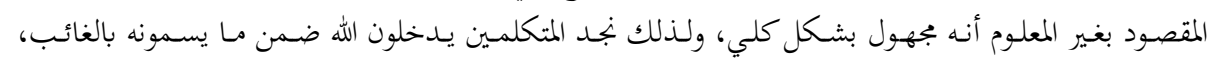

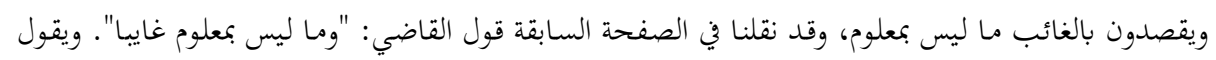

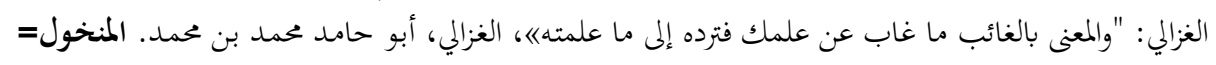


والعلة الجامعـة: هي الرابطة بين الشـاهد (المقيس) عليه والغائب (المقيس)، وهـذه

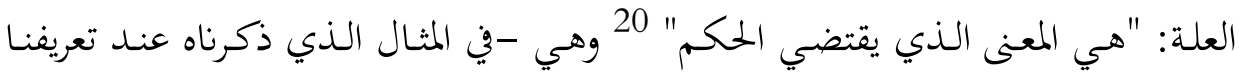

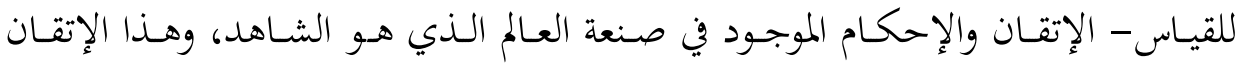

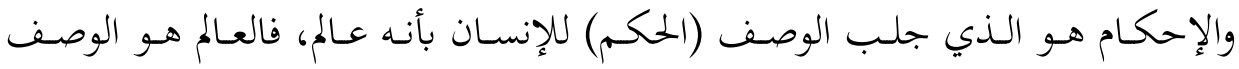

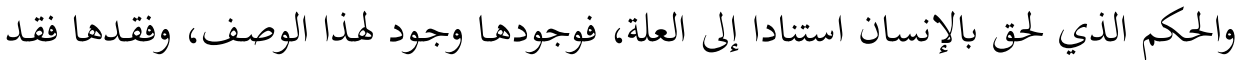
له، ومن ثم يتعدى هذا الحلكم -الوصف بالعالم- من الشاهد (المقيس) عليه إلى الغائب (المقيس)، والغائب هنا هو الله، فيوصف الله عندها بأنه عالم. وإلحاق الحكىم بالغائب مـن خهلال الشـاهد ليس مقصورا على العلة، بـل هنـاك أربعة

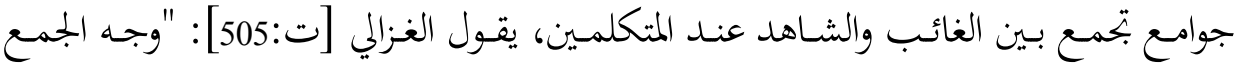

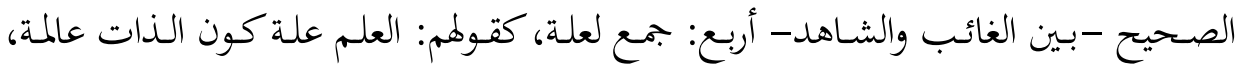
فليكن كذلك في الغائب، وجمع بالحقيقة، كقولمم: حقيقة كونه عالما قيام العلم به، والجماع

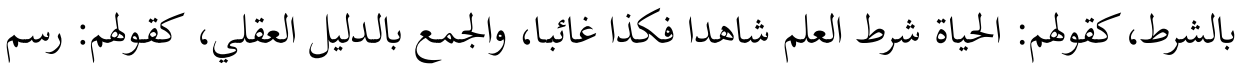

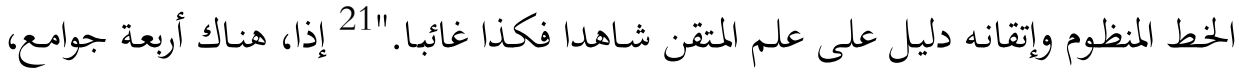

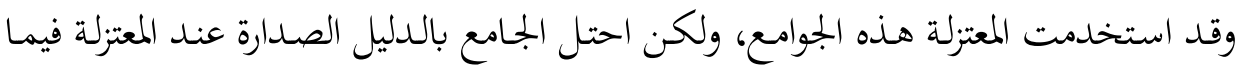
يتصل بمسائل التوحيد، واحتل الجامع بالعلة الصدارة فيما يتصل بمسائل العدل الإلهي، يقول ولإل

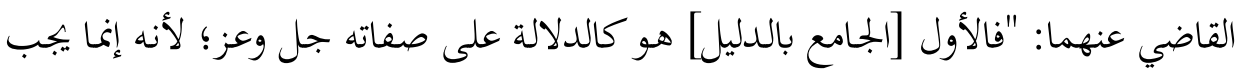
كونه قادرا لثبوت الطريق فيه، وهو صحة الفعل، وهذه حال كثير من صفاته تعالى، وأكثر

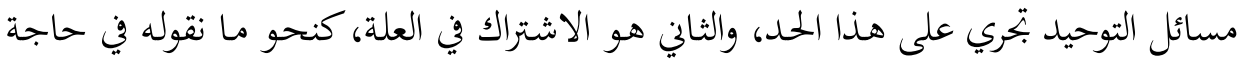

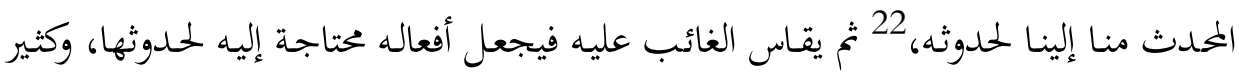

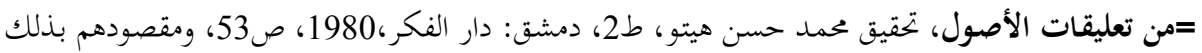

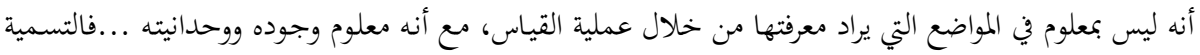
بالغائب فيها نوع من التجوز .

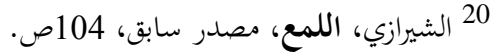

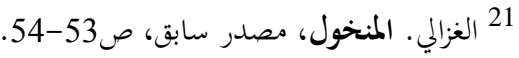
22 يقصد أن تصرفاتنا لا تقع بذاتما وإنما منا. 
من مسائل العدل يبنى على ذلك."23

وقـد أثبت المعتزلة كل الصفات الإلهية لله: أي كونه قادرا عالما مريدا سميعا بصيرا

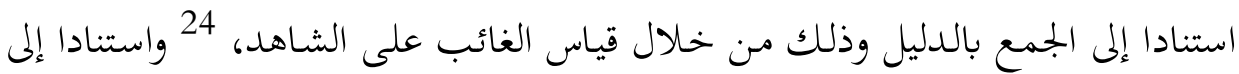

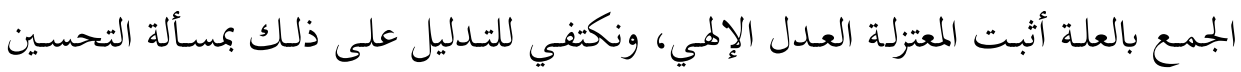

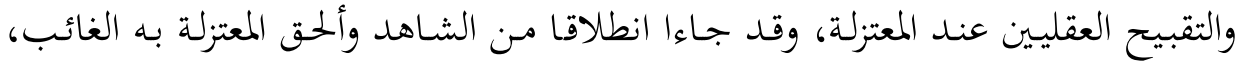

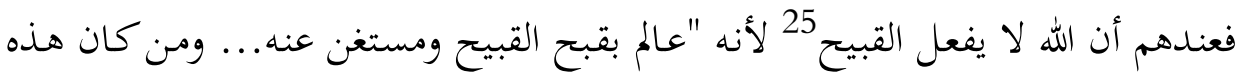

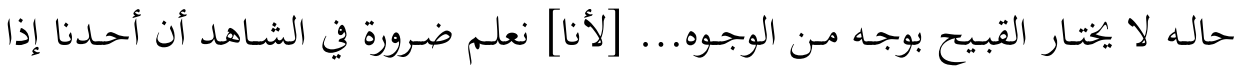

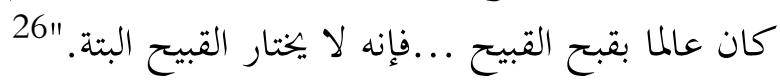

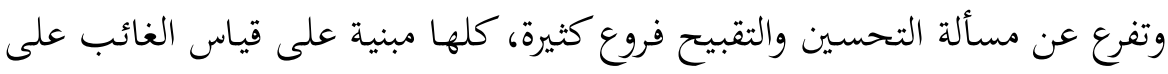

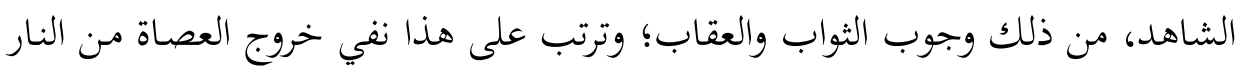

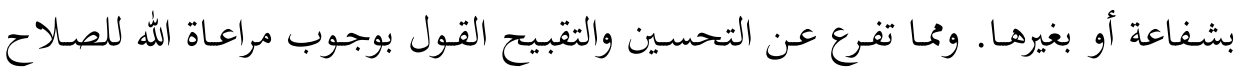
والأصلح فيما يخص عباده، يقول الغزالي [ت:505] عن دليل المعتزلة في هـذه المسألة:

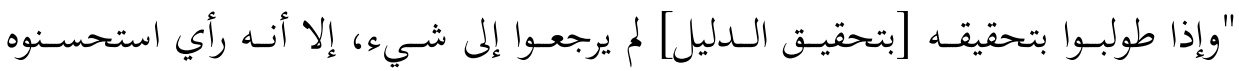

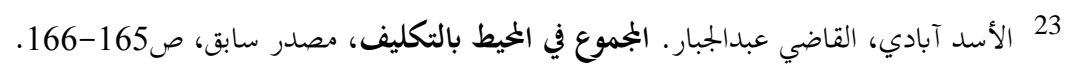

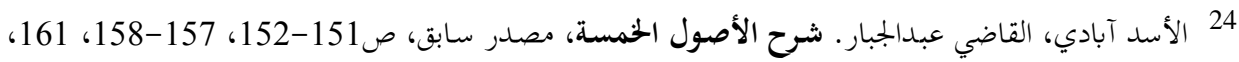

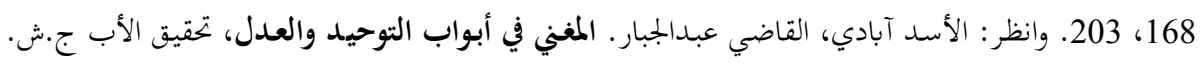

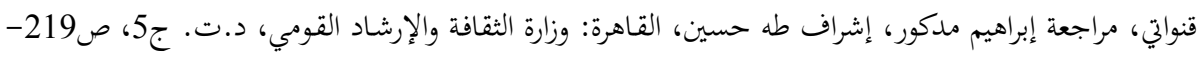

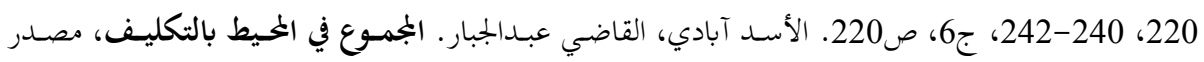

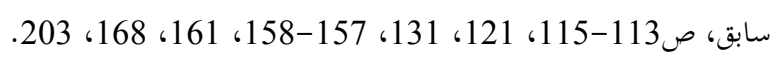

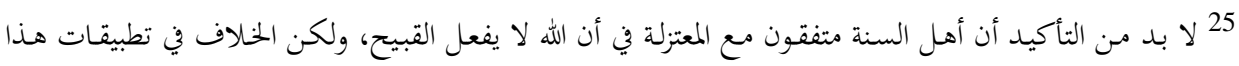

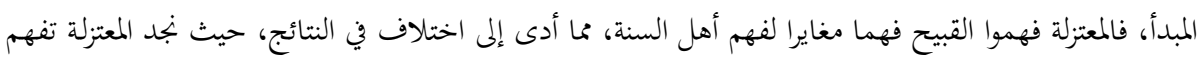

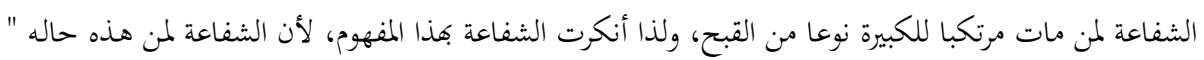

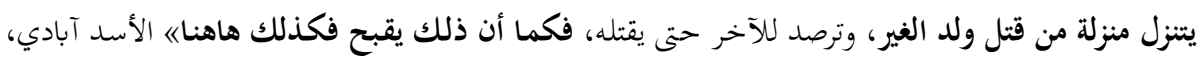
26 المصدر السابق، صبدالجبار. شرح الأصول الخمسة، مصدر سابق، صن82. 


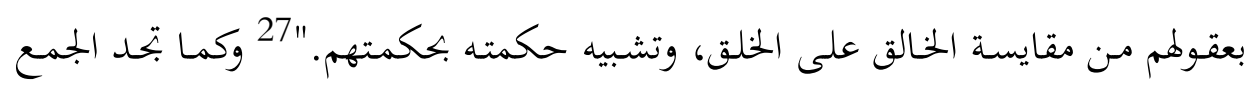

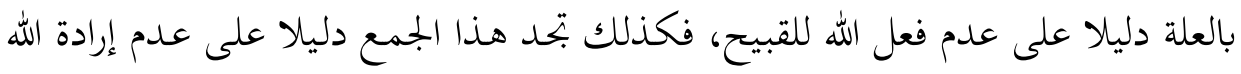

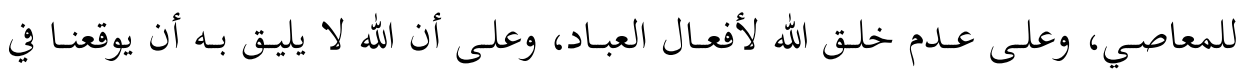

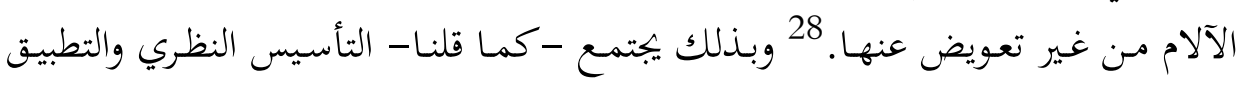

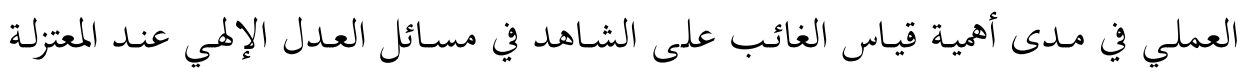
اعتمادا على الجمع بالعلة.

مع ملاحظة أن الفرق بين الجمع بالدليل والجمع بالعلة هو أن الحكم على الشاهد

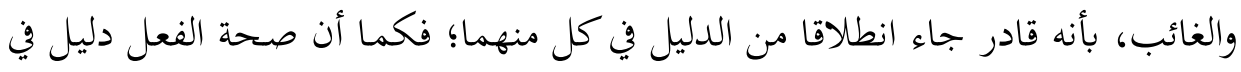

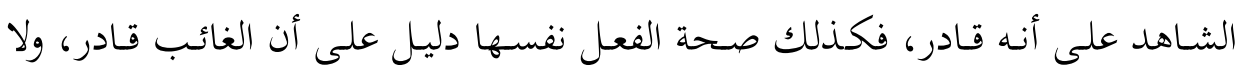
يوجد دليل في الشاهد والغائب غير هذا الدليل، بينما الحلكم على الشاهد والغائب بأنه

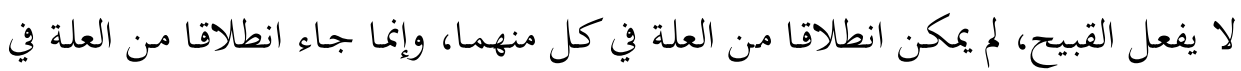

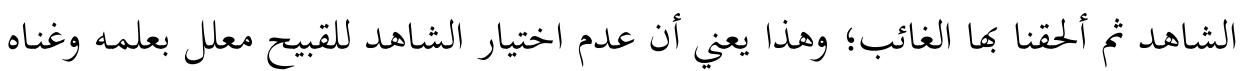

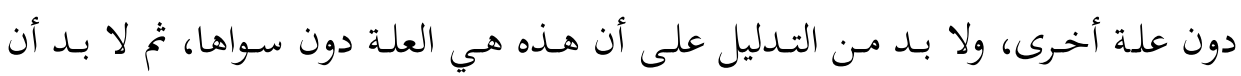

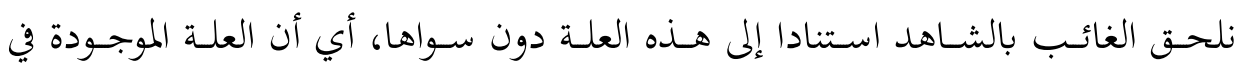

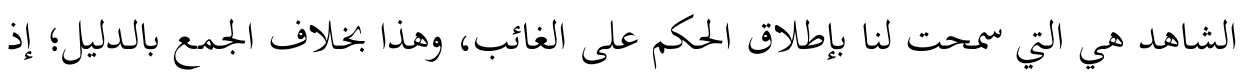
الدليل موجود في كليهما 29.

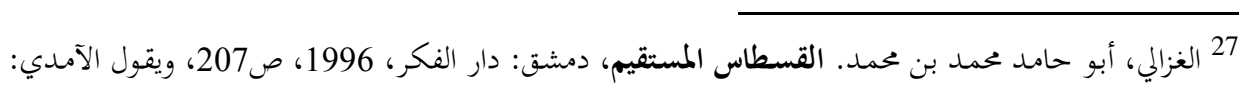

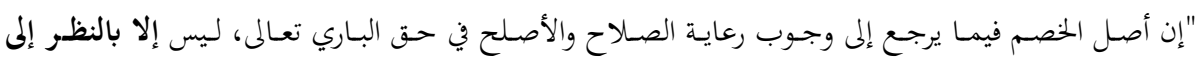

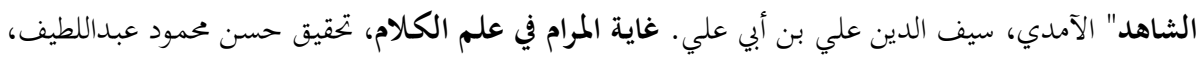

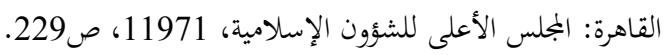

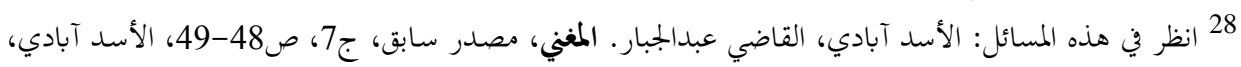

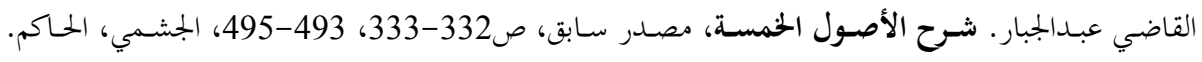

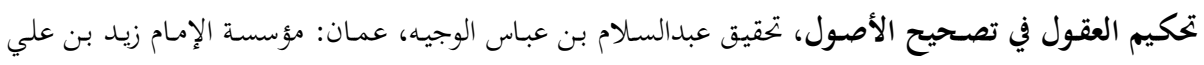
الثقافية، 2001، صنيم العول في تصحيح الاصول، 117، 123، 143.

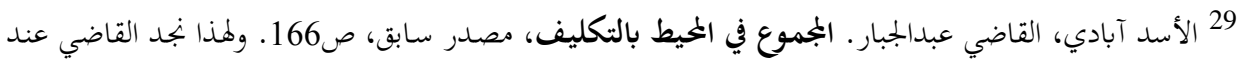

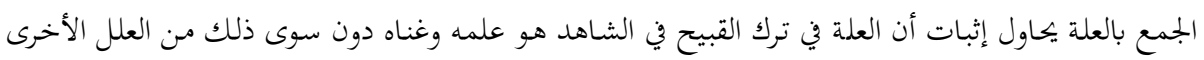

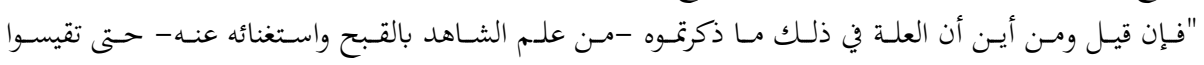




\section{ثانيا: مصدر القياس}

أما عن مصدر هذا القياس فهناك من يرى أن أصله يوناني، ومن هؤلاء من يبالغ إلى

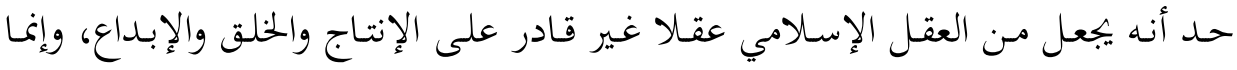
ديدنه الاتباع، وأغلب هؤلاء - في تصوري- تنقصهم المعرفة بالعقل الإسلامي وإبداعاته الإسي

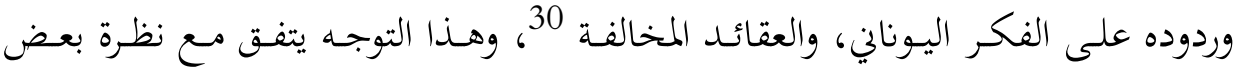
المستشرقين الذين يحاولون تقزيم الفكر الإسلامي، واستبعاد مقدرته على الإبداع، وبالتالي فالفكر الفلسفي الإسلامي ليس إلا وليد الفكر اليوناني 31.

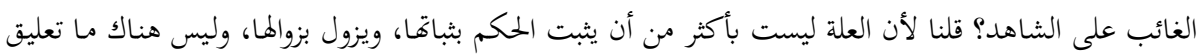

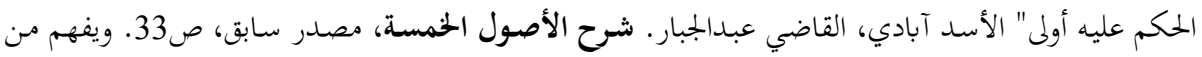

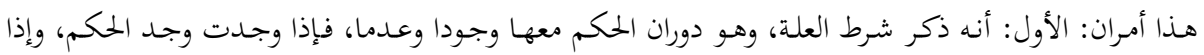

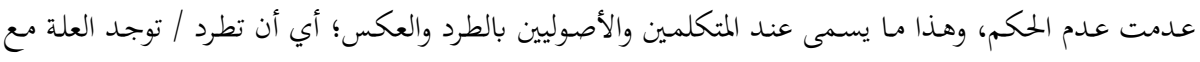

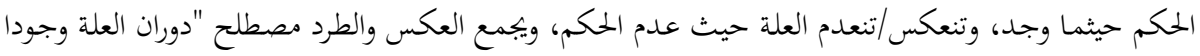

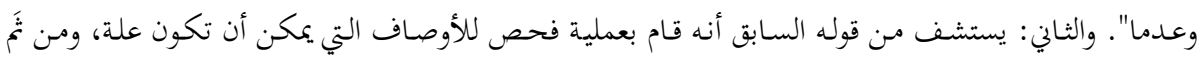

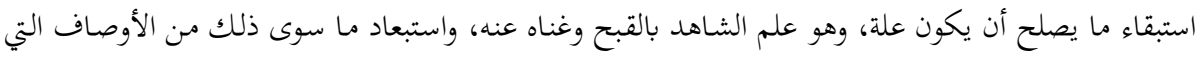

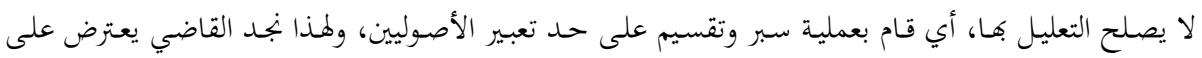

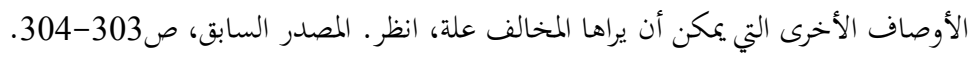

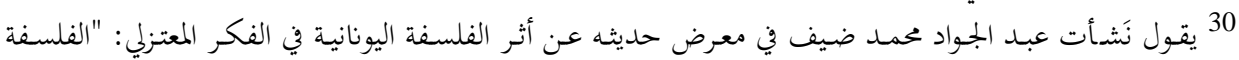

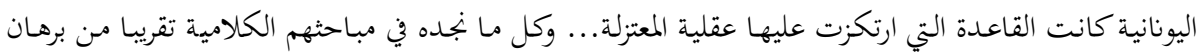

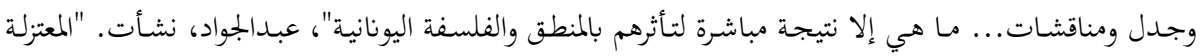

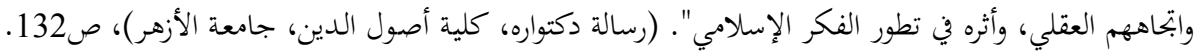

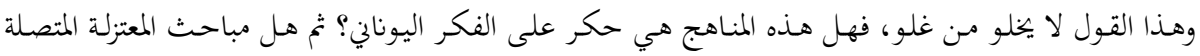

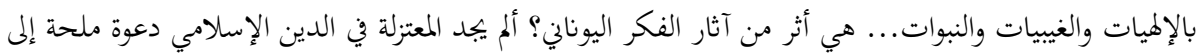

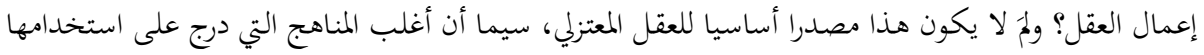

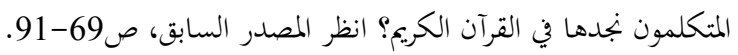

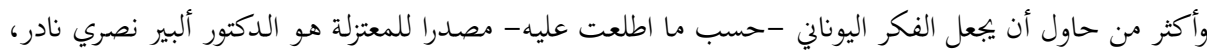

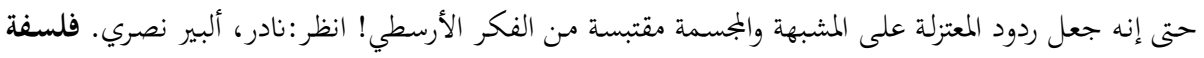

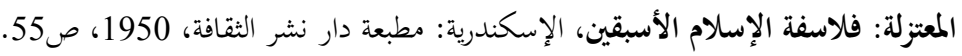

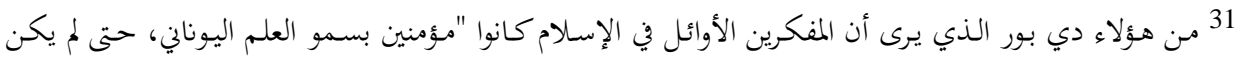

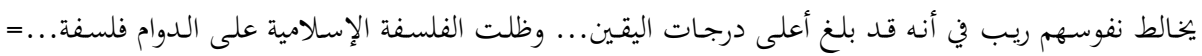

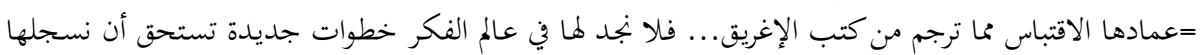


والذي أراه أن هذا القياس انتقل من أصول الفقه الذي جاء به الشافعي [ت:204]

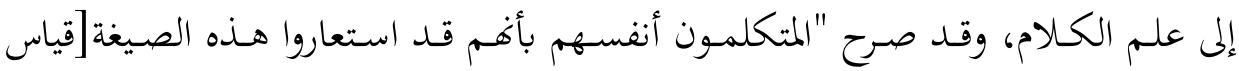

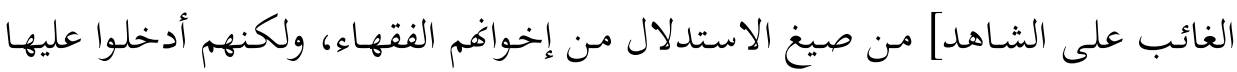

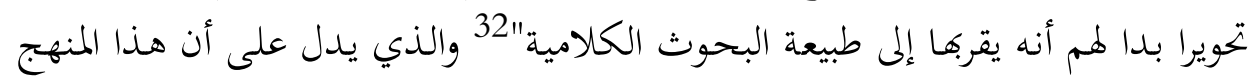

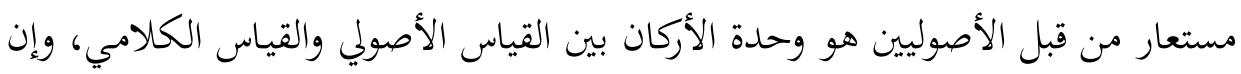

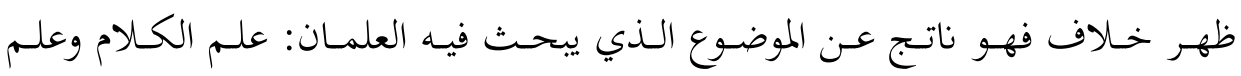

له"، دي بور، ت. ج. تاريخ الفلسفة في الإسلام، نقله إلى العربية عبدالهادي أبو ريدة، تونس: الدار التونسية،

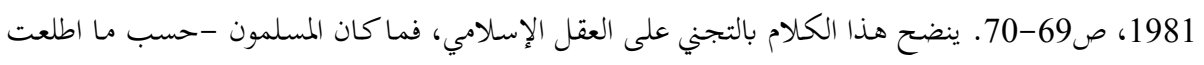

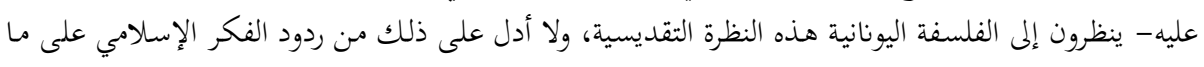

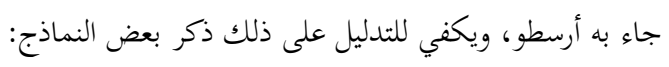

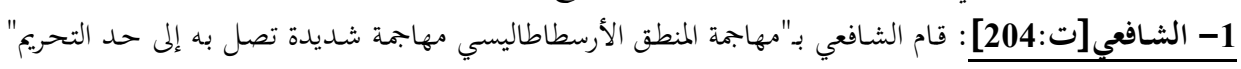

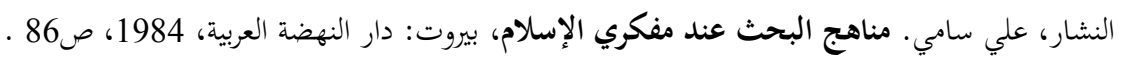

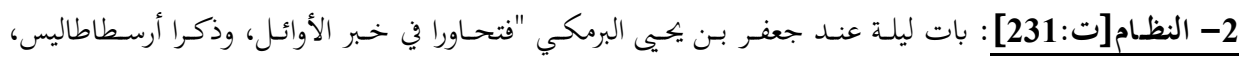

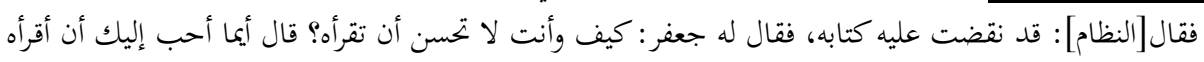

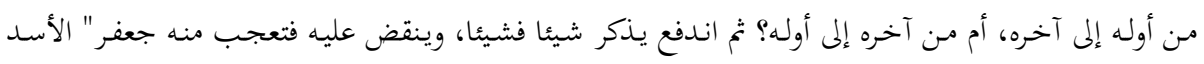

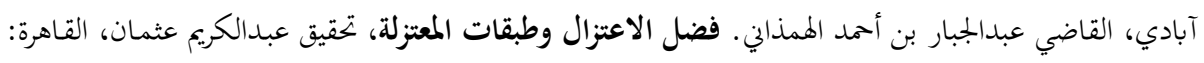

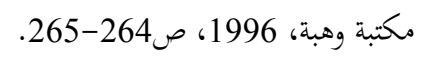

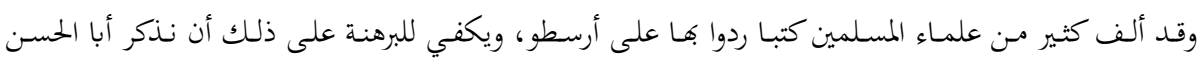

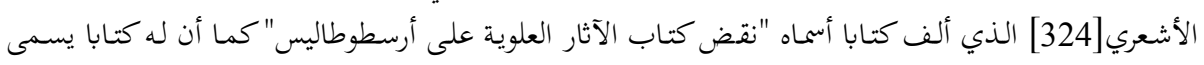

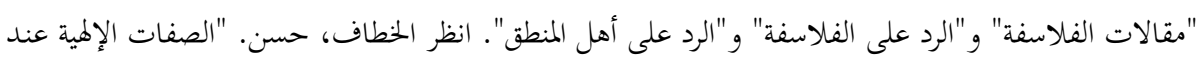

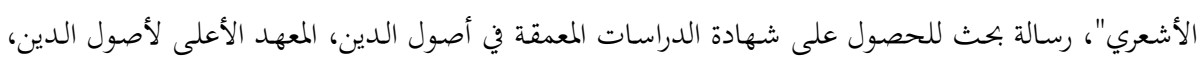

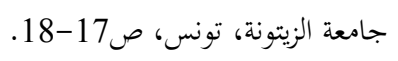

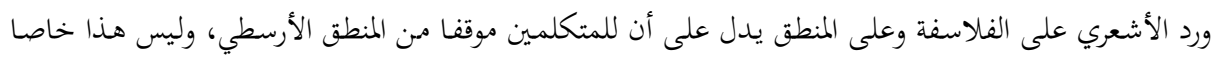

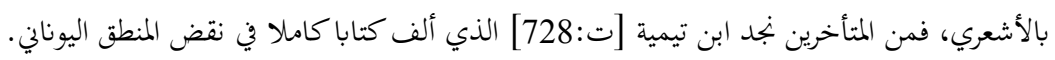

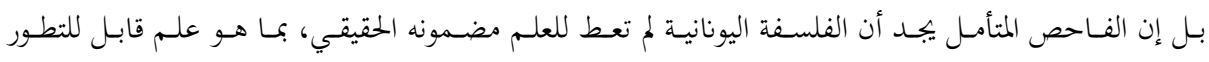

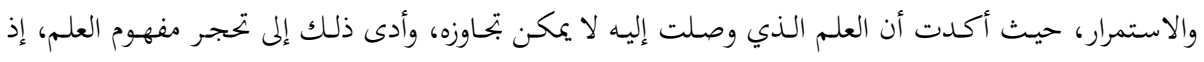

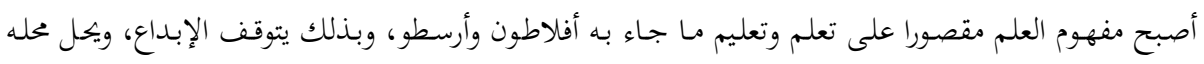

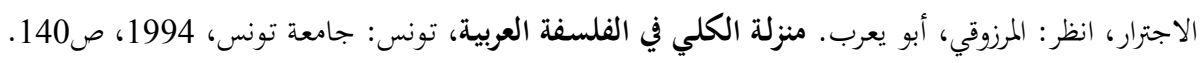

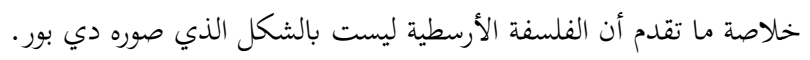

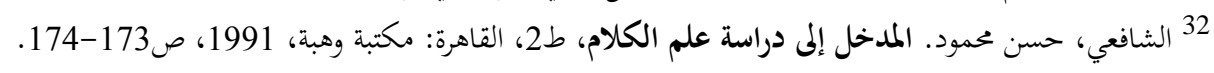


الأصول. 33 ولكـن إذا كان هـذا المنهج يرجعع في أصله إلى الأصـوليين، وكـان الشـافعي

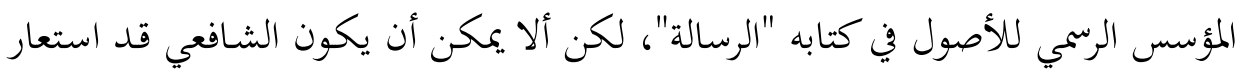

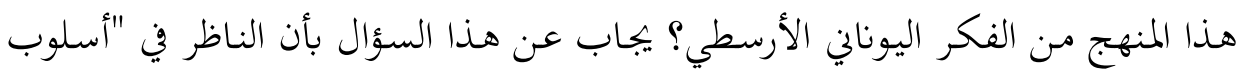

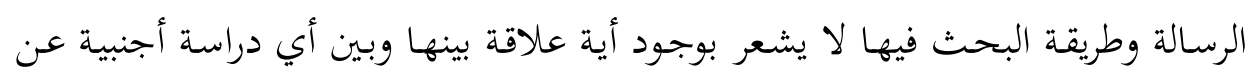

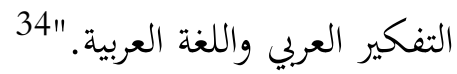

هذا من حيث نفي تأثر الشافعي بالمنطق الأرسطي بشكل عام، أما عن العلاقة بين

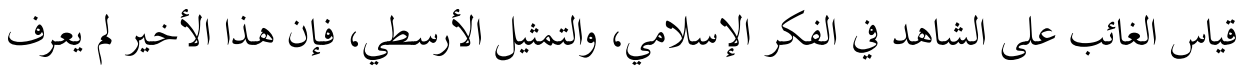

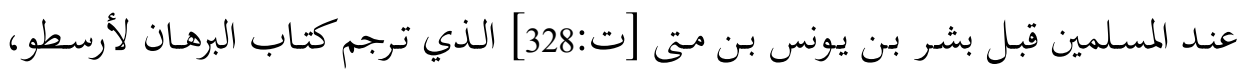

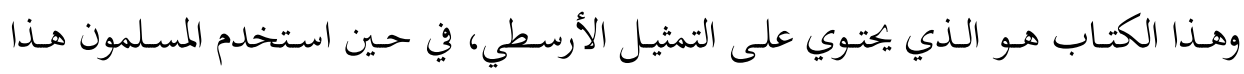

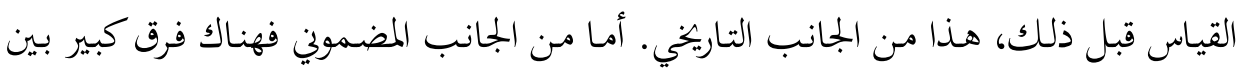

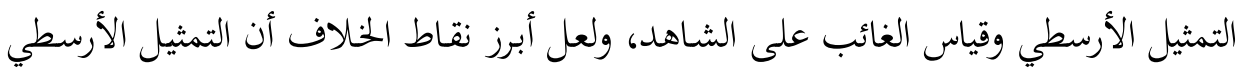

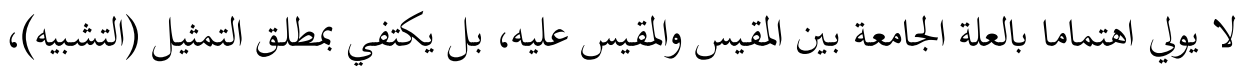

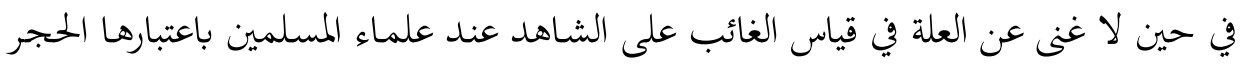

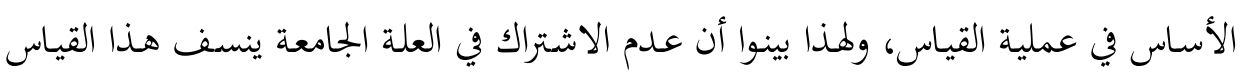

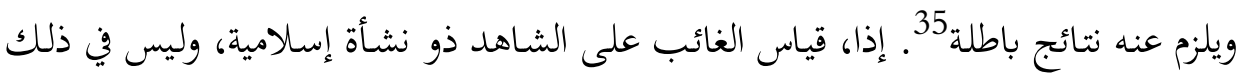

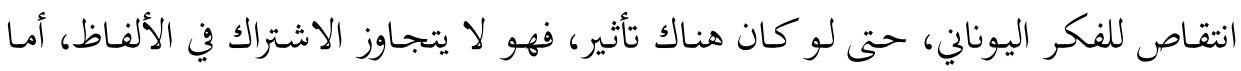
من حيث المضامين، والأركان فلا.

33 قارن بين أركان القياس التي ذكرةا سابقا وبين أركاها عند الأصوليين، وانظر كنموذج للقياس عند الأصوليين:

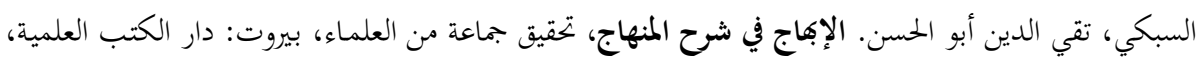

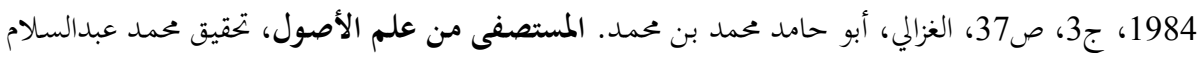

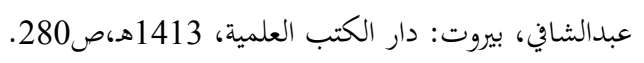
34

35 أممد، عطا الله مختار محمود. "مناهج الاستدلال لدى المتكلمين والفلاسفة المسلمين"، مصدر سابق، ص278.

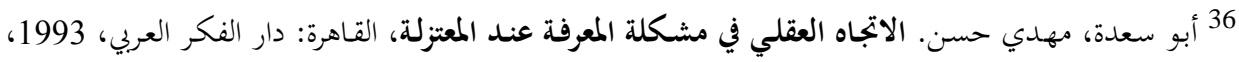




\section{ثالثا: إسهام القياس في إثبات الصفات الإلهية والعدل الإلهي عند المعتزلة}

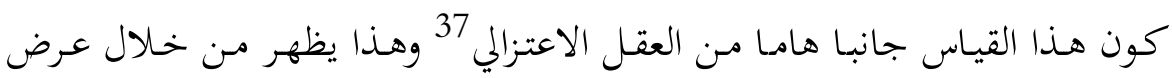

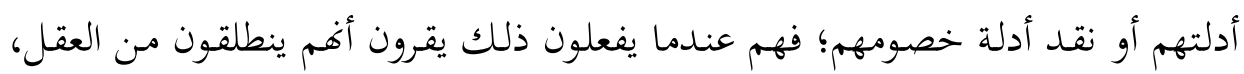

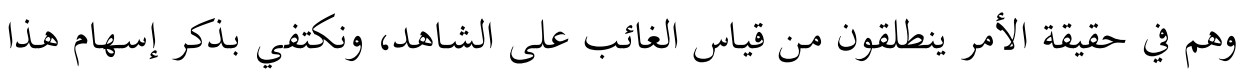
القياس في إثبات الصفات الإلهية عند المعتزلة.

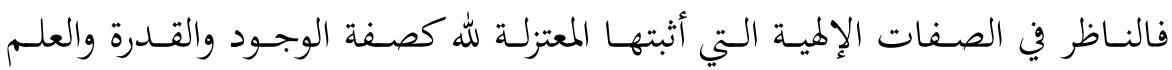

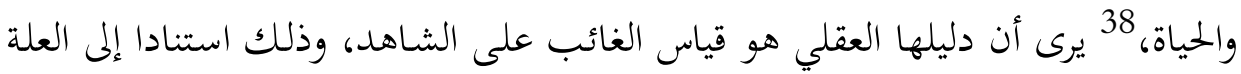

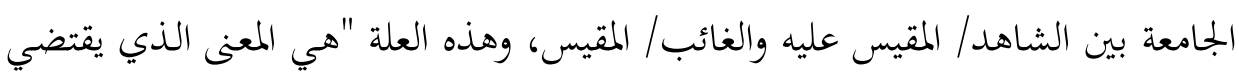
الحكم". (الماكة بن 39

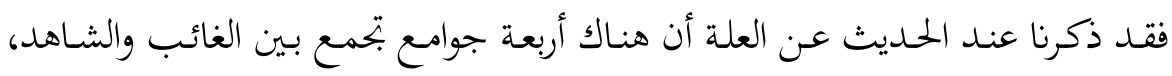

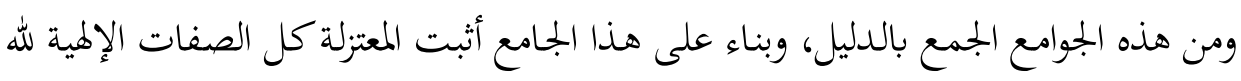

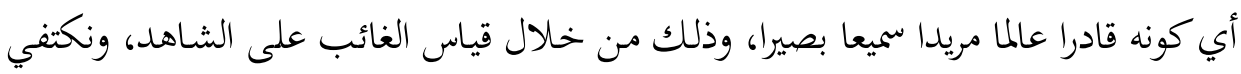

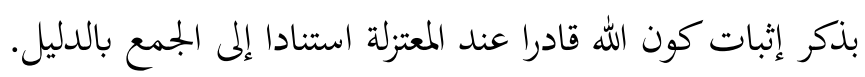

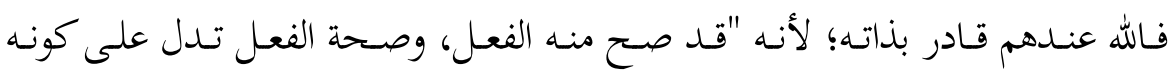

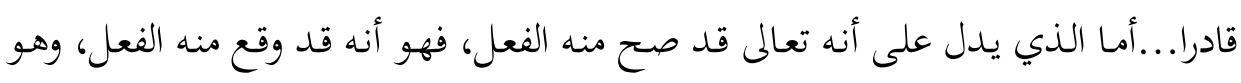

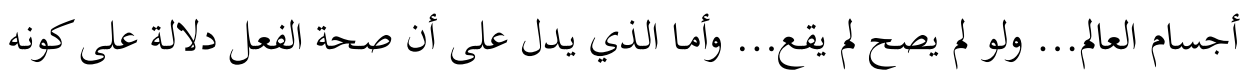

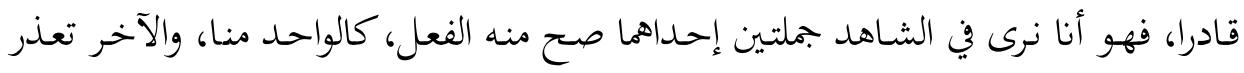

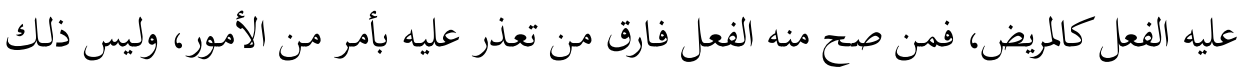

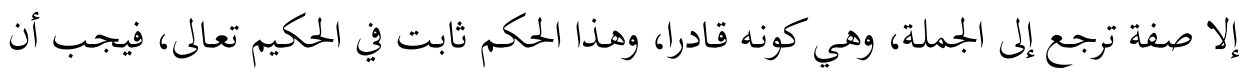

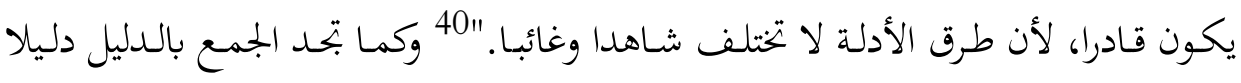

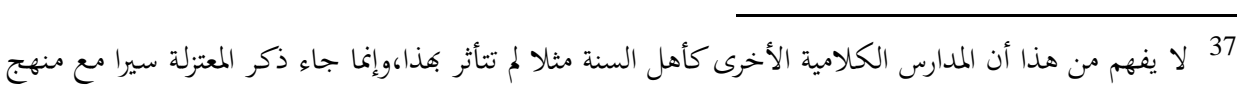
البحث.

$$
\begin{aligned}
& 38 \text { الأسد آبادي، القاضي عبدالجبار . شح الأصول الحمسة، مصدر سابق، ص182. }
\end{aligned}
$$

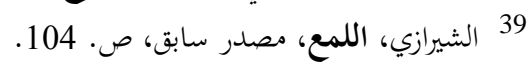

40 الأسد آبادي، القاضي عبدالجبار . شرح الأصول الخمسة، مصدر سابق، ص151-152. 
على إثبات كون الله قادرا انطلاقا من الشاهد، فكذلك تجد الجمع بالدليل دليلا على إثبات

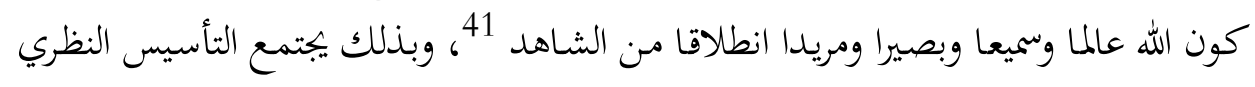

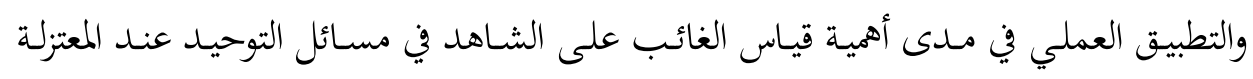
اعتمادا على الجمع بالدليل.

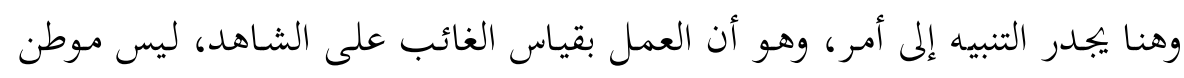

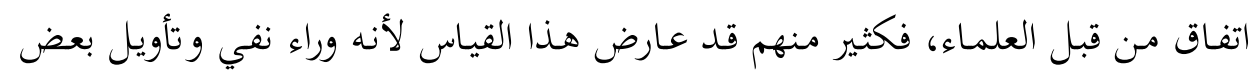

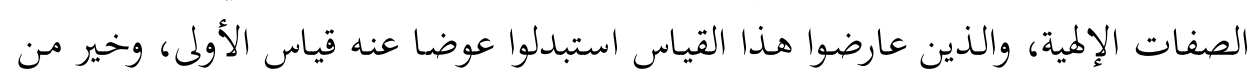

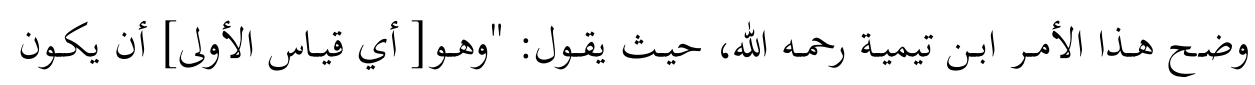

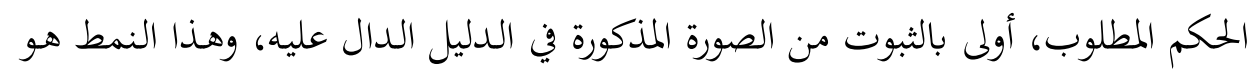

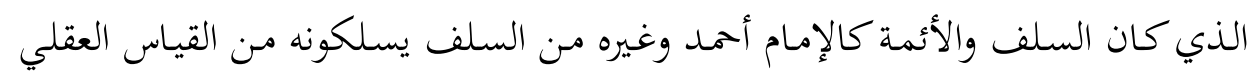

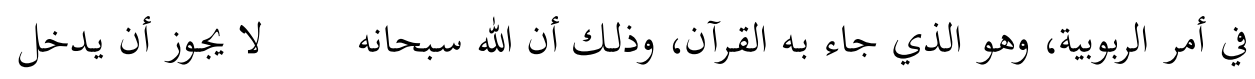

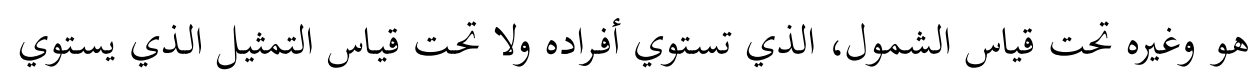

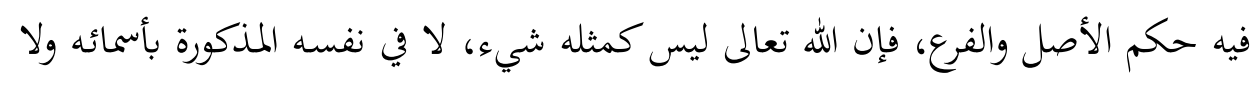

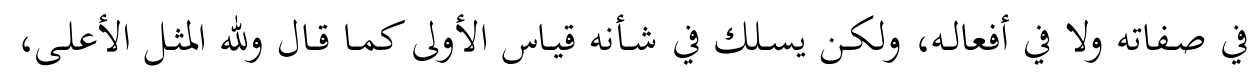

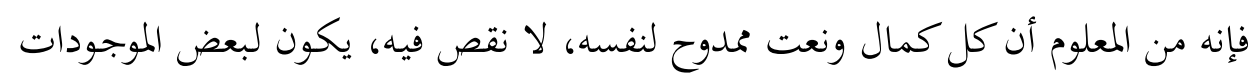

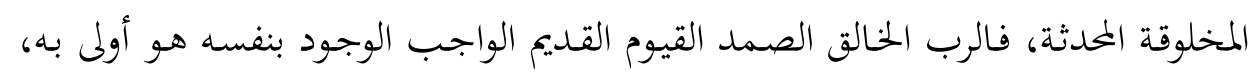

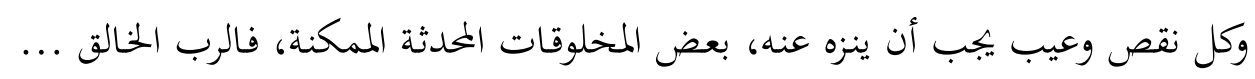
أولى بأن ينزه عنه".

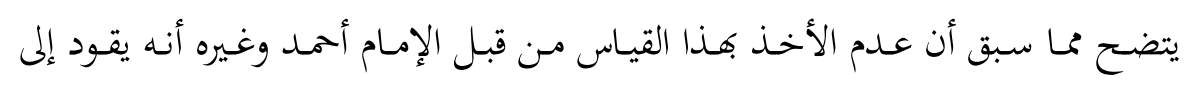

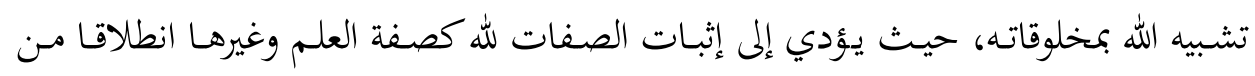

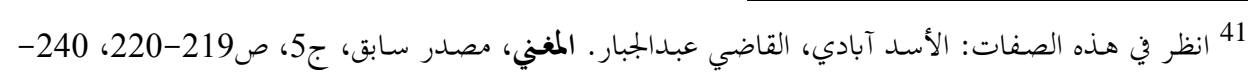

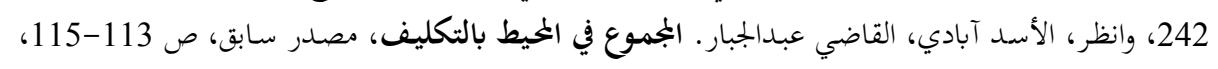

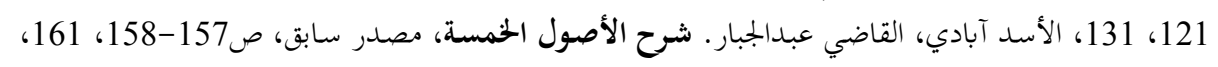
168، 203.

42 ابن تيمية، تقي الدين أبو العباس أمد. شرح العقيدة الأصفهانية، القاهرة: دار الكتب الحديثة، 1960، ص 73. 
المخلوق، وكذا نفي بعض الأشياء عن الله انطلاقا من المخلوق، وهذا مـا سيتضح معنا في المئي

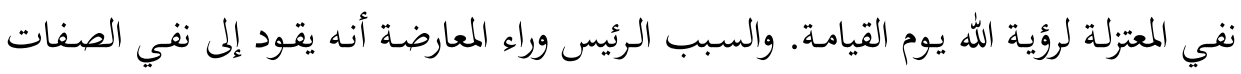

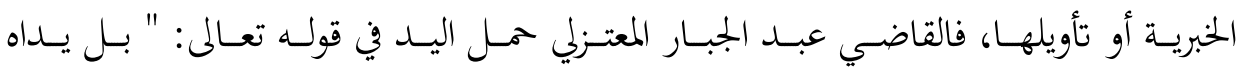

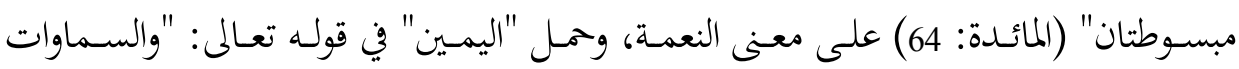

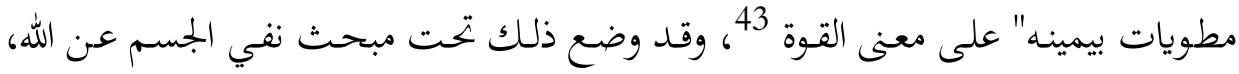

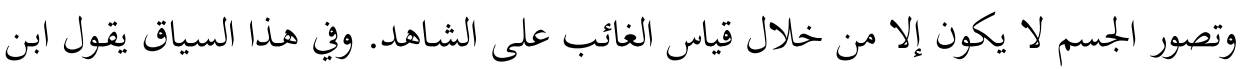

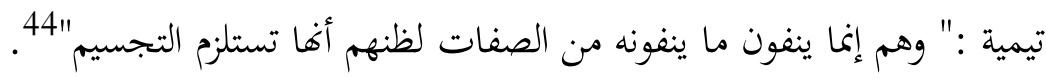

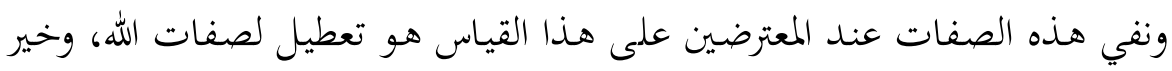

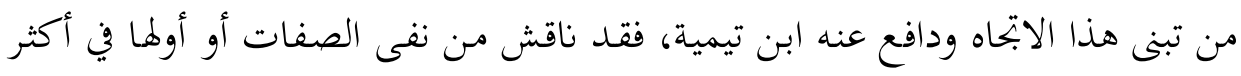

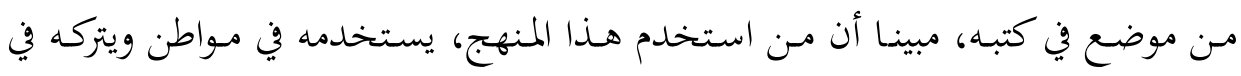

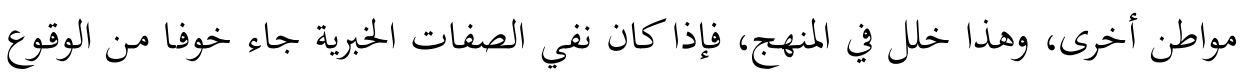

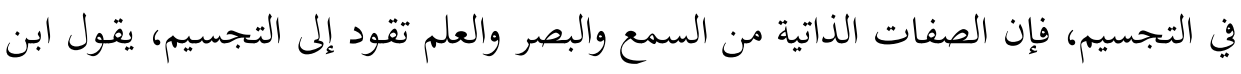

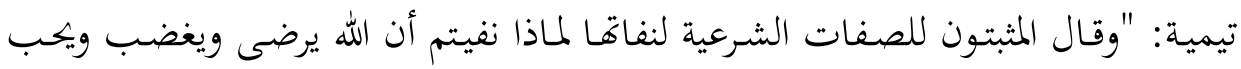

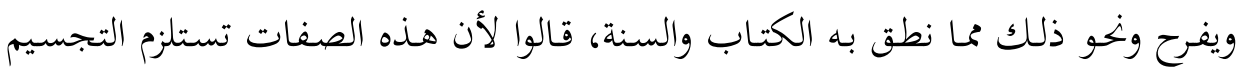

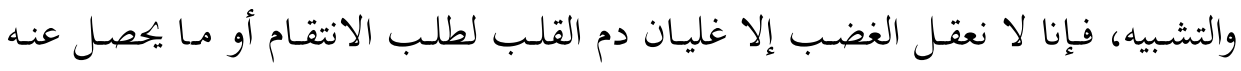

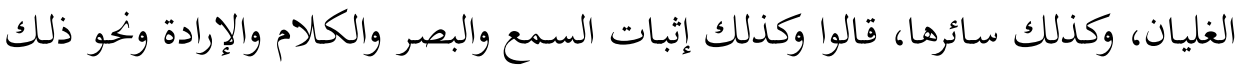

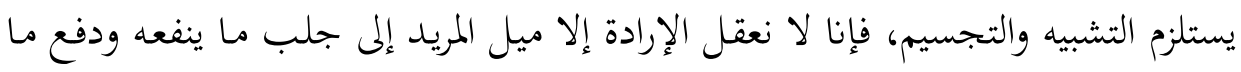

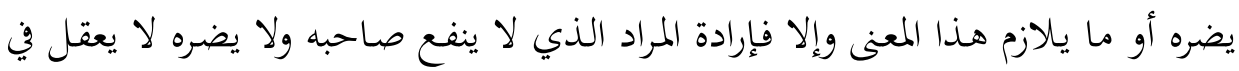

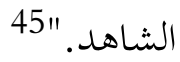

إذا اعتمد المعتزلة على قياس الغائب على الشاهد في إثبات الصفات الإلهية من

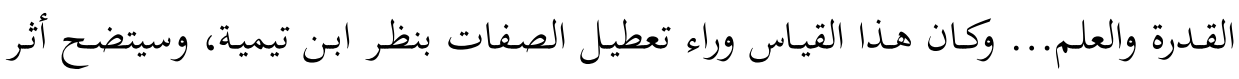
هذا القياس أكثر في المبحث الثاني.

$$
\begin{aligned}
& 43 \text { الأسد آبادي، القاضي عبدالجبار . شرح الأصول الخمسة، مصدر سابق، ص228. }
\end{aligned}
$$

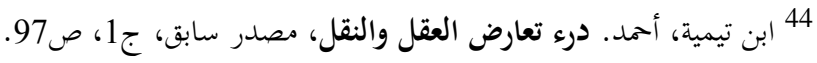

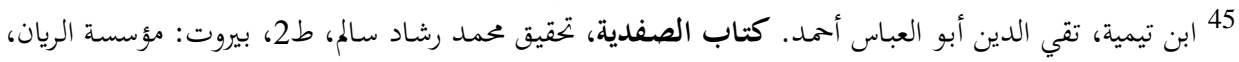

$$
\text { 1406، ج2، ص36. }
$$




\section{رابعا: أثر القياس في العدول عن السنة النبوية}

سنذكر هنا بعض النماذج المتصلة بالسنة النبوية التي تدل على أثر هذا القياس في

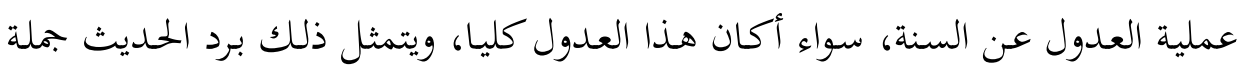

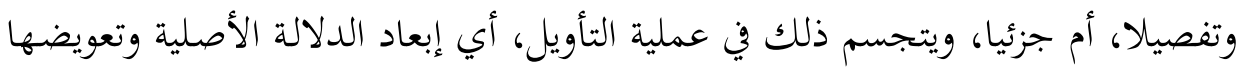

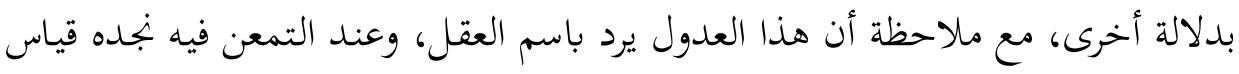

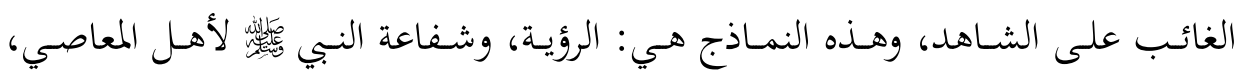
والصراط، والميزان، وذبح الموت.

\section{1. قياس الغائب على الشاهد وصلته بالعقل والرؤية:}

ففيما يتصل بعلاقة هذا القياس بالرؤية، وإطلاق كلمة العقل عليه، يقول القاضي

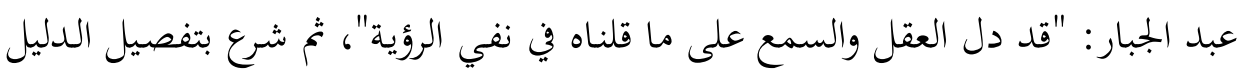

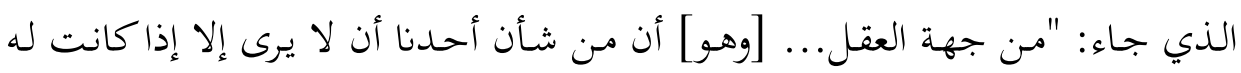

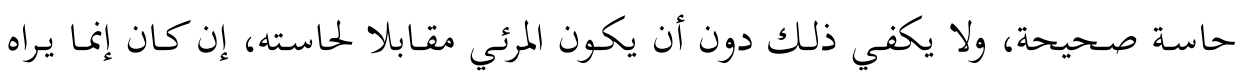

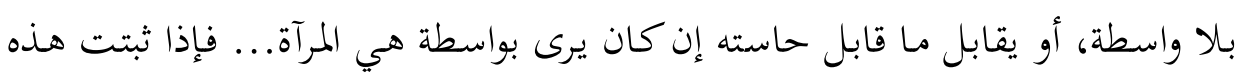

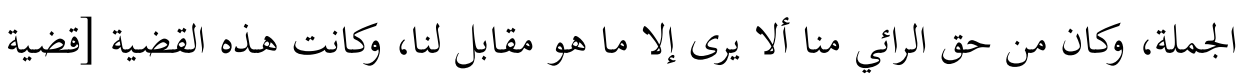

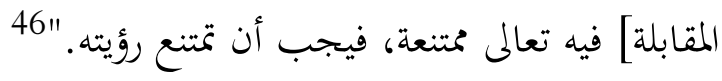

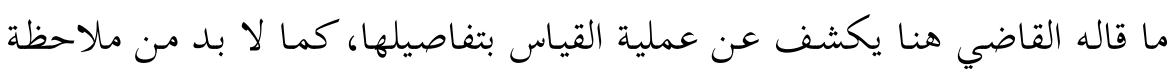

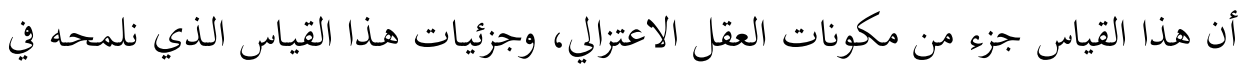

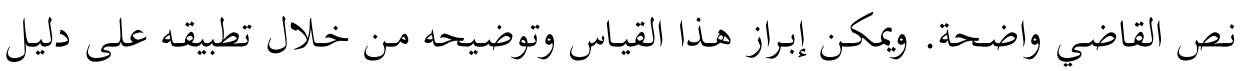

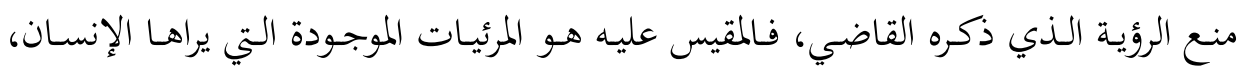

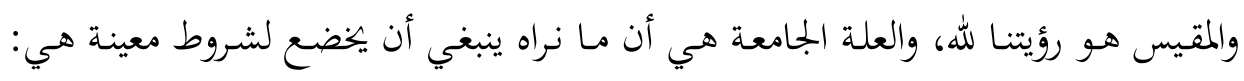

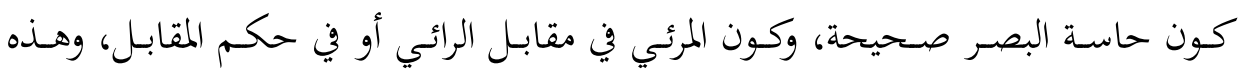

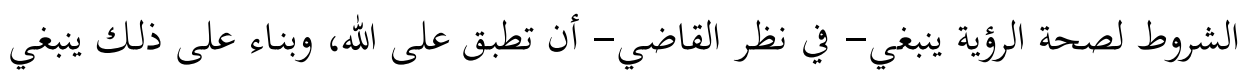

46 الأسد آبادي، القاضي عبدالجبار. الجمموع في الخيط بالنكليف، مصدر سابق، ص208. الأسد آبادي، القاضي

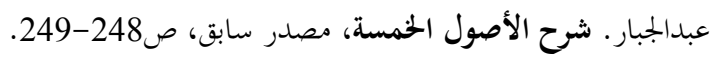




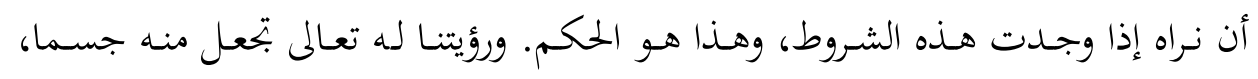

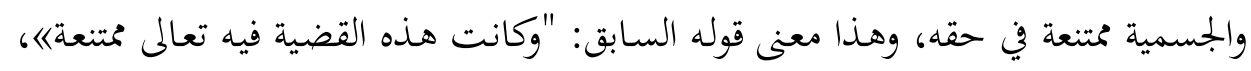

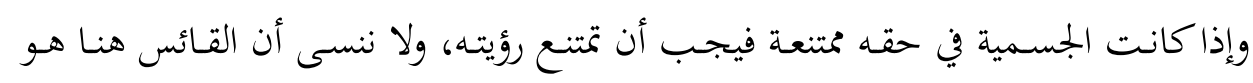
القاضي عبد الجبار، وبذلك تكتمل هذه الأركان.

إذا، القول برؤية الله في نظر المعتزلة يؤدي لا عحالة إلى أن يكون الله جسما على غرار

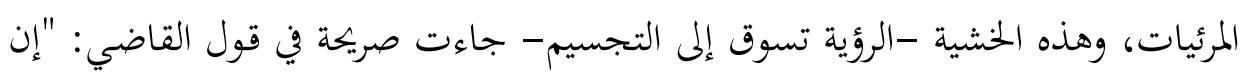

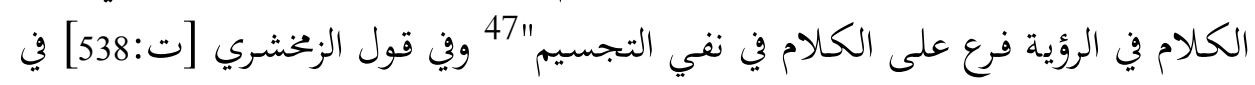

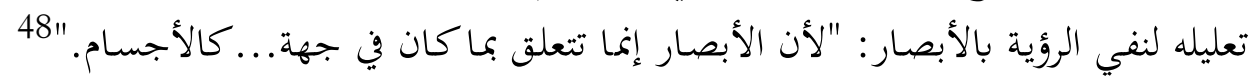

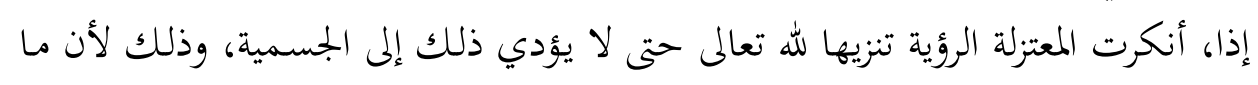

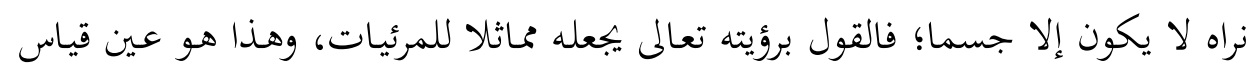

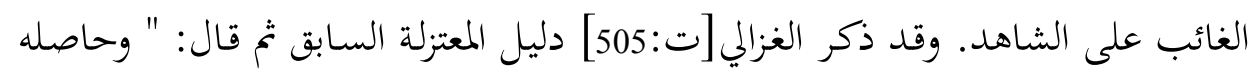

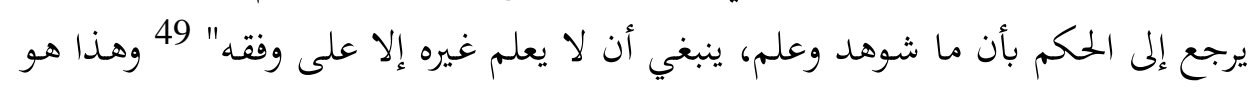

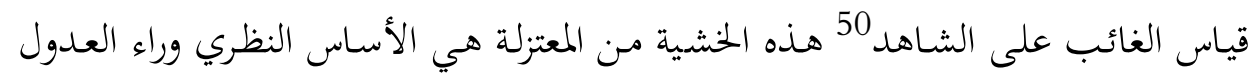

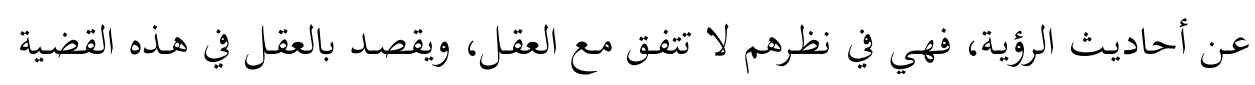

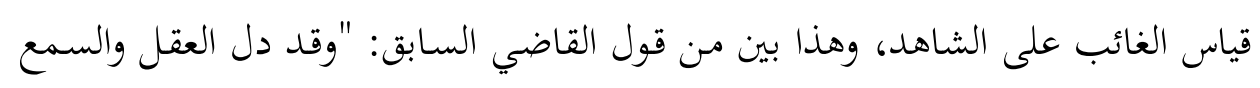
على ما قلناه في نفي الرؤية."

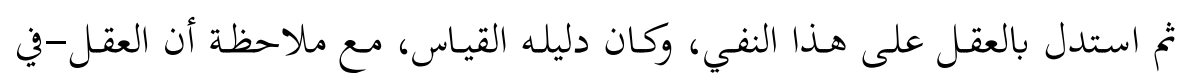

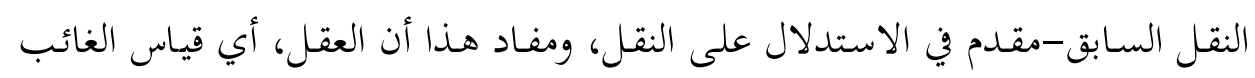

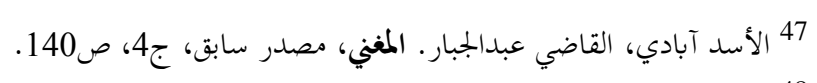

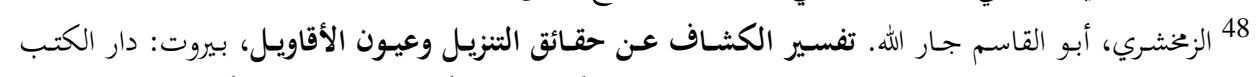

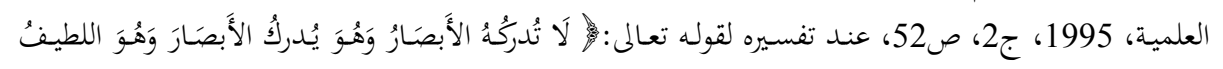

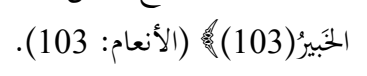

49 الغزالي، أبو حامد حممد بن محمد. الاقتصاد في الاعتقاد، تحتيق موفق فوزي الجبر، دمشق: دار الحكمة،

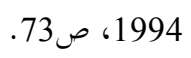

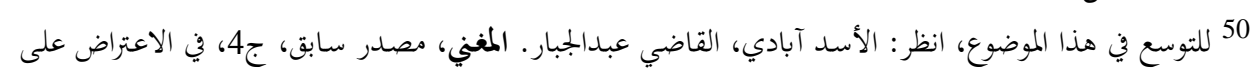
من يقول بالرؤية، ومحاولة الاستدلال على عدم حصولا الإنا بالعقل والنقل. 


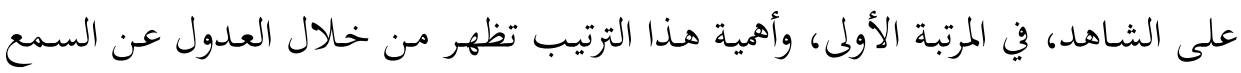

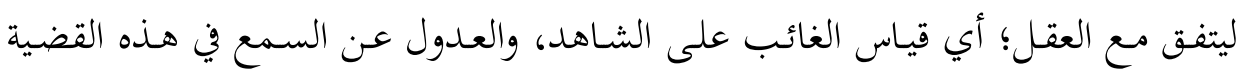

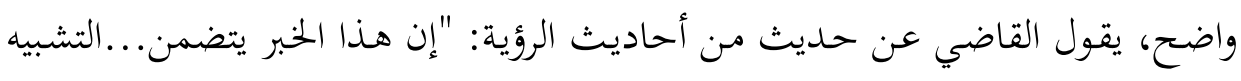

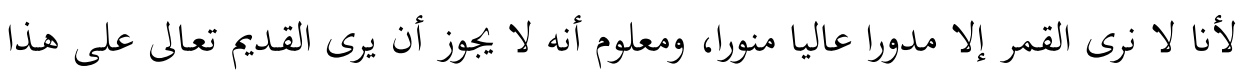

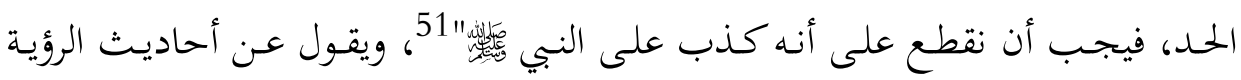

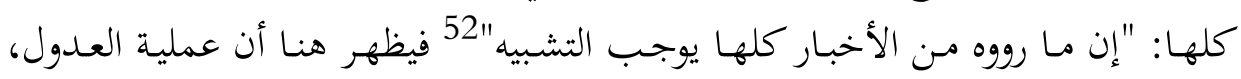

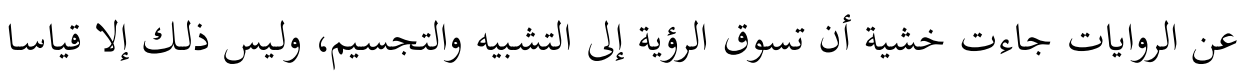

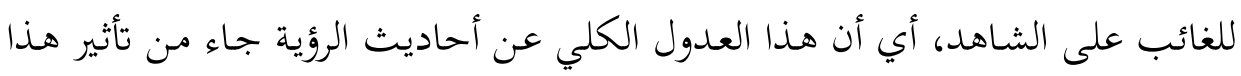

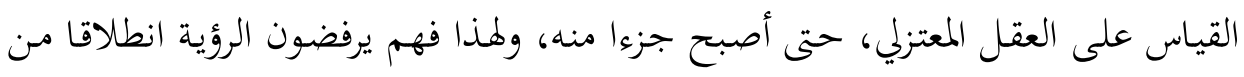
الأدلة العقلية التي في حقيقتها ترجع إلى هذا القياس.

والعدول هنا جاء عن الحديث، وهو أحد شقي السمع، ويكتمل هذا العدول بشقيه

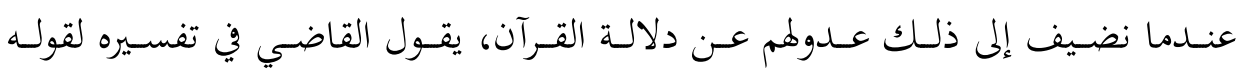

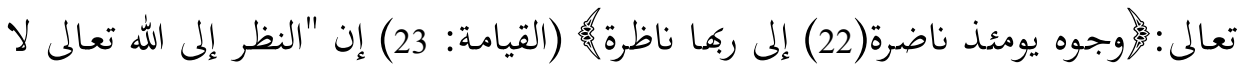

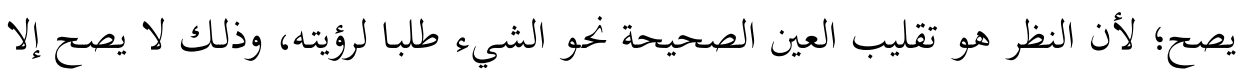

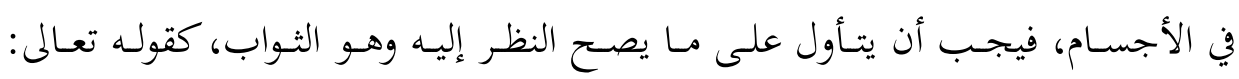

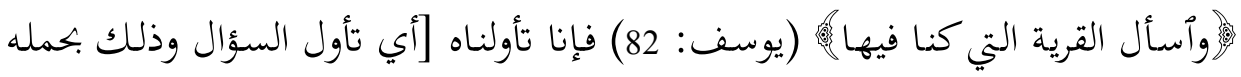

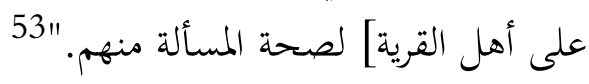

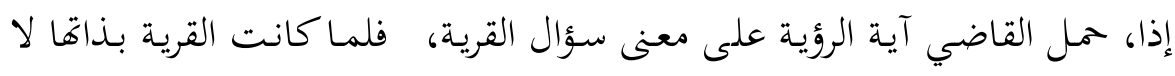

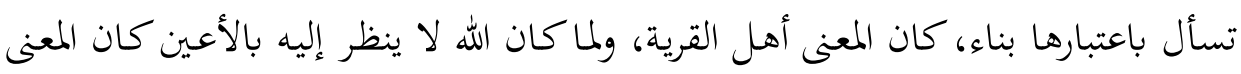

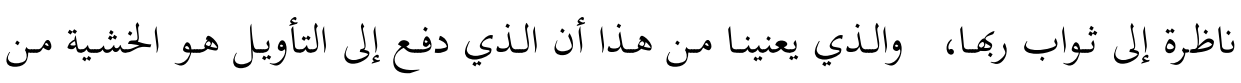

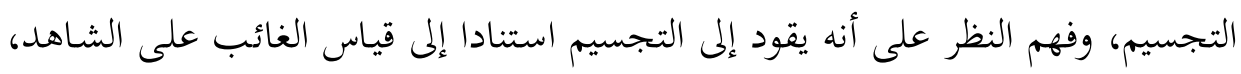

$$
\begin{aligned}
& 51 \text { الأسد آبادي، القاضي عبدالجبار. شرح الأصول الخمسة، مصدر سابق، ص268. }
\end{aligned}
$$

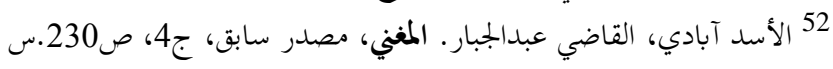

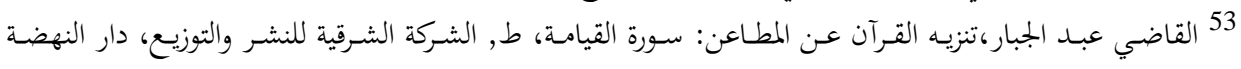


وهذا الأخير هو العقل، وعلى ضوء العقل أولت آية الرؤية. فنخلص من ذلك إلى القول

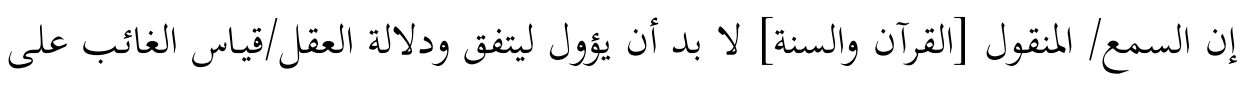
الشاهل.

\section{2. قياس الغائب على الشاهد وصلته بالعقل والشفاعة:}

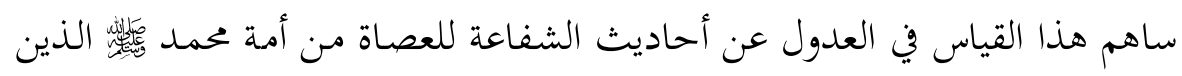

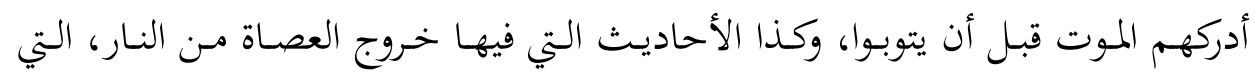

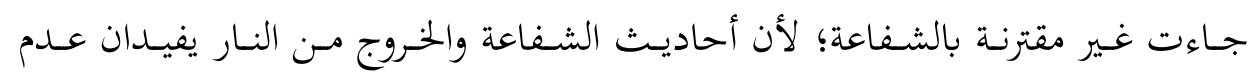

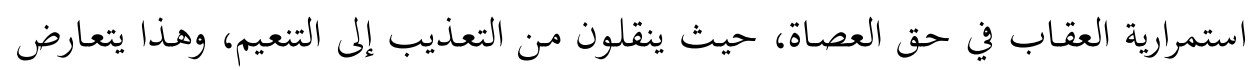

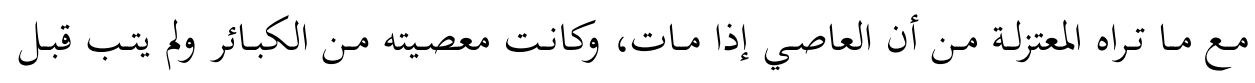

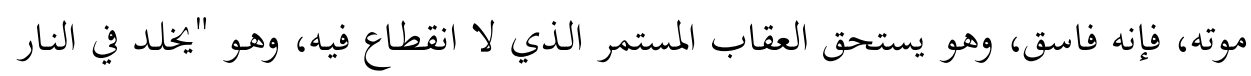

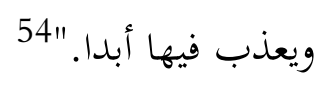

والأساس النظري لاستحقاق العاصي العقوبة، وبالتالي الخلود المستمر في النار، هو

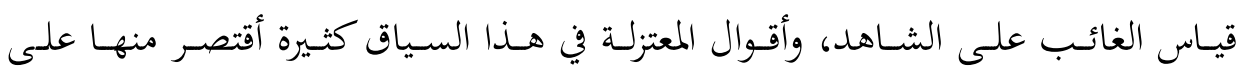

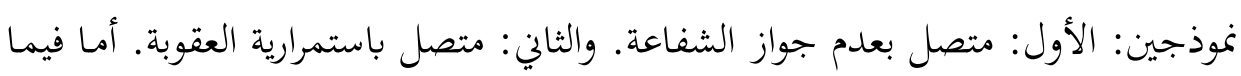

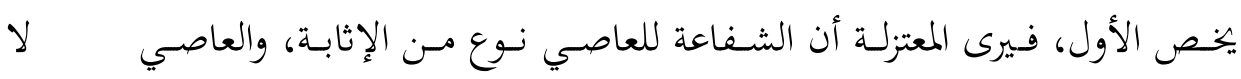

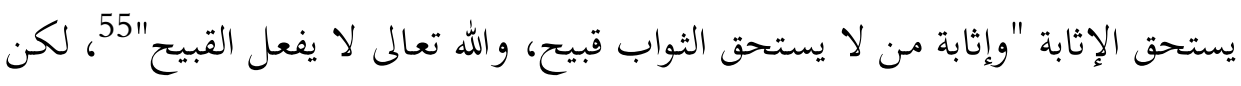

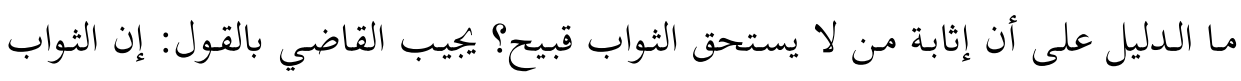

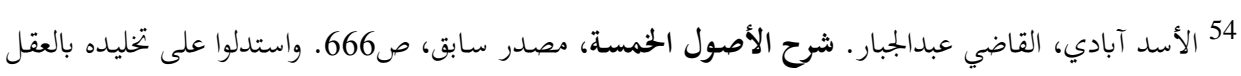

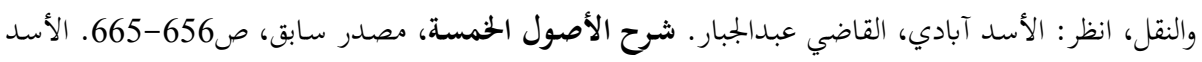

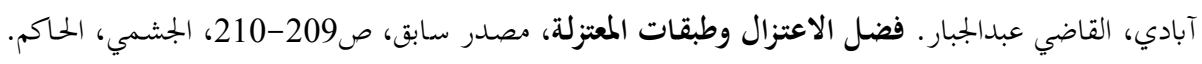

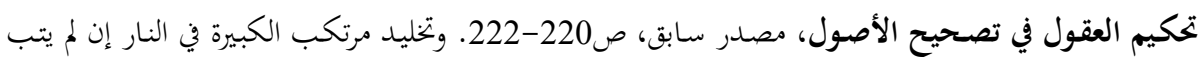

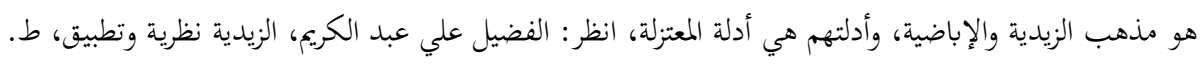

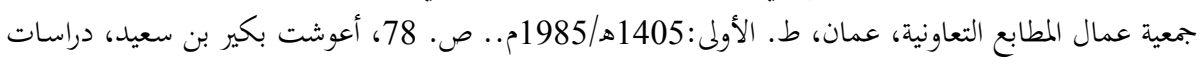

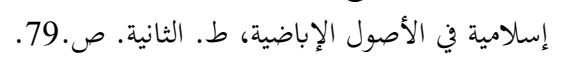

55 الأسد آبادي، القاضي عبدالجبار . شرح الأصول الخمسة، مصدر سابق، ص667. 
"يستحق على طريقة التعظيم والإجلال، وما هذا سبيله لا يحسن دون الاستحقاق؛ ولهذا

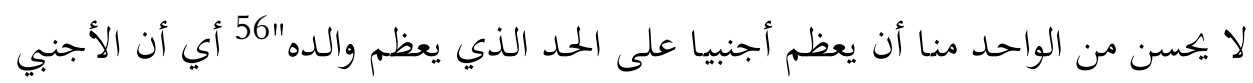
لا يستحق التعظيم كالوالد، فإذا عظم الولد والده والأجنبي على درجة واحدة كاندي الوان الولد

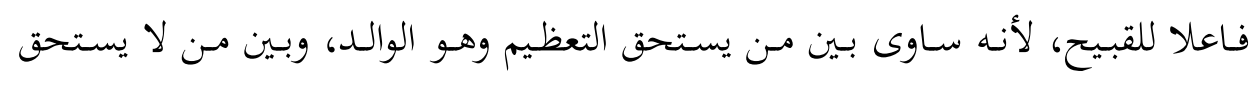

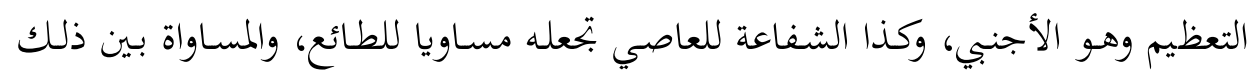

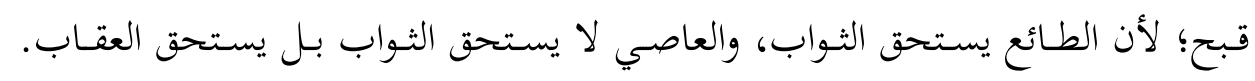

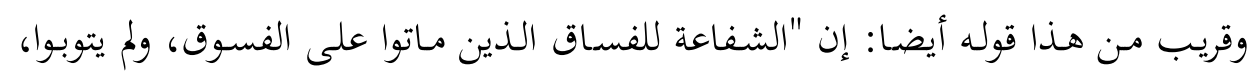
تتنزل منزلة الشفاعة لمن قتل ولد الغير، وترصد للآخر حتى يقتله، فكما أن ذلك يقبح

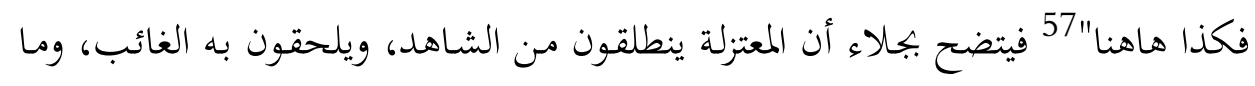

$$
\text { يقبح في الثاهد يقبح في الغائب. }
$$

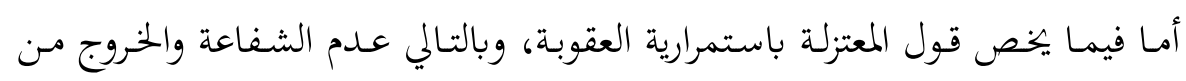

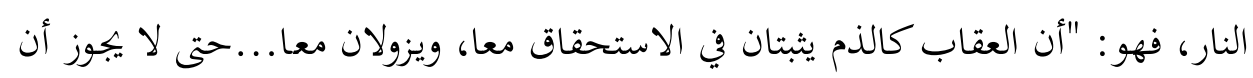

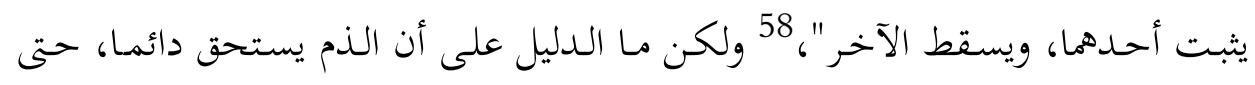

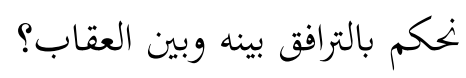

يرى القاضي أن الجواب عن هذا السؤال "لا يقع فيه إشكال، فمعلوم أن من لطم والده،

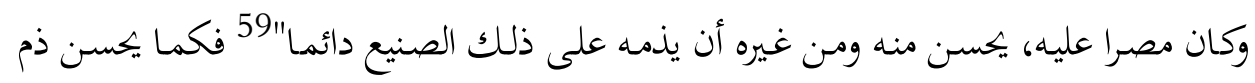
اللاطم في هذا المثال بشكل دائم، فكذا يحسن ذم العاصي -الذي ارتكب كبيرة ولم يتب على الدوام، وإذا حسن ذمه حسنت عقوبته، للتلازم بينهما، وإذا حسـن هذان، فمـن القبح

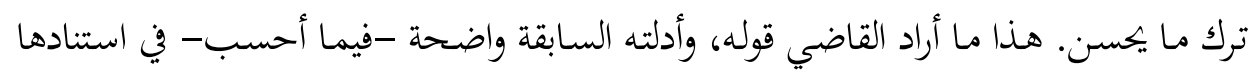
على القياس، أي ما غاب ينبغي أن يكون على وفق ما علم وشوهد.

$$
\text { 56 } 56
$$

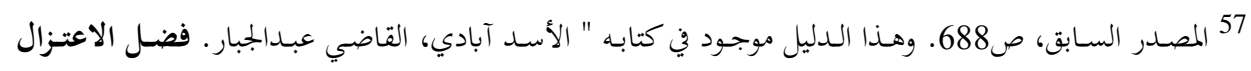
وطبقات المعتزلة، مصدر سابق، ص209.

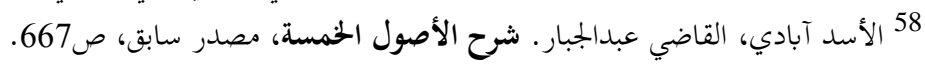
59 المصدر السابق، ص668. 


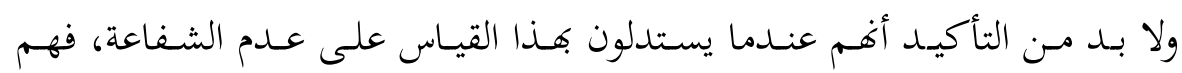

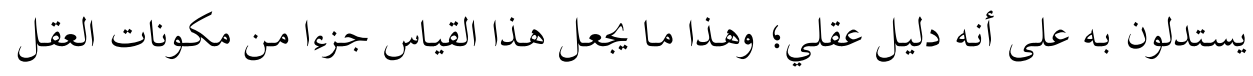

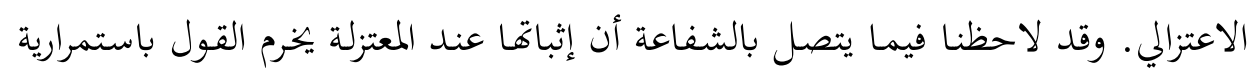

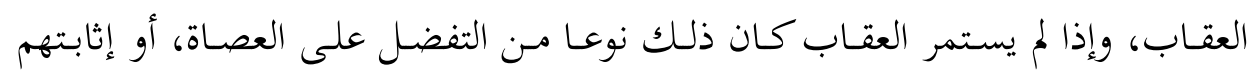

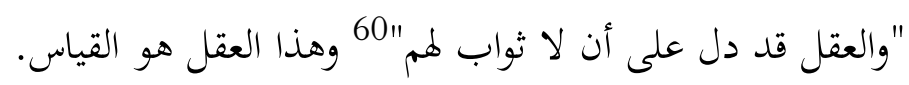

\section{3. قياس الغائب على الثاهد وصلته بالعقل والميزان:}

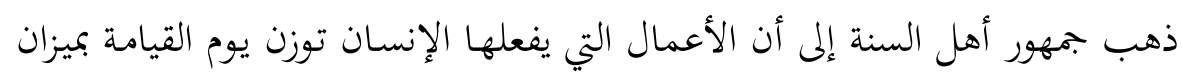

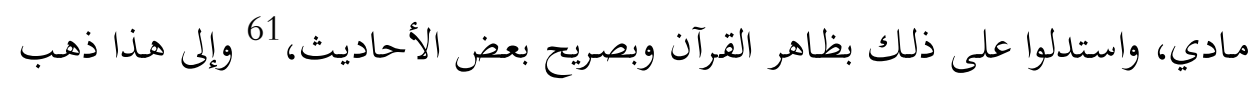

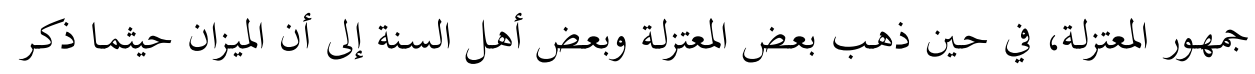

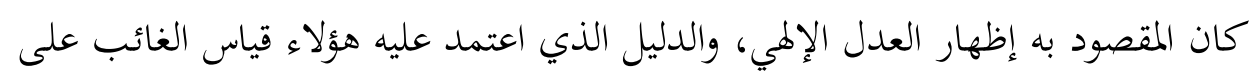

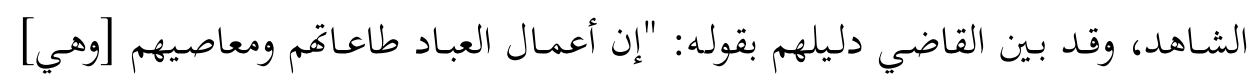

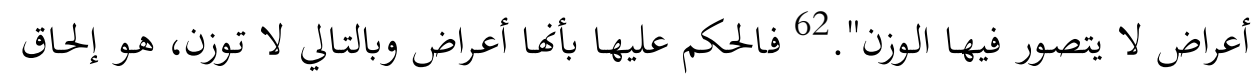

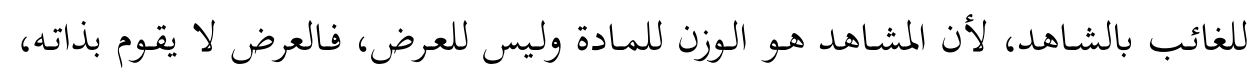

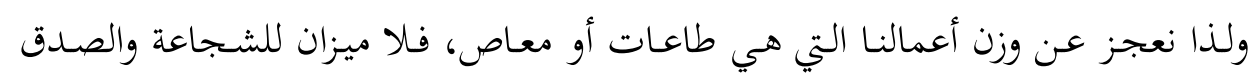

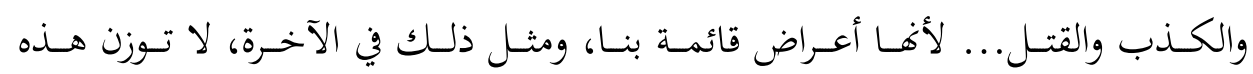

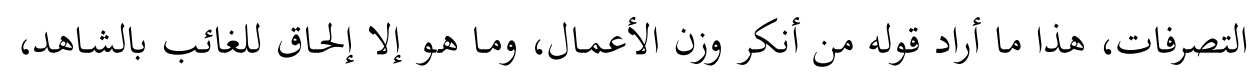

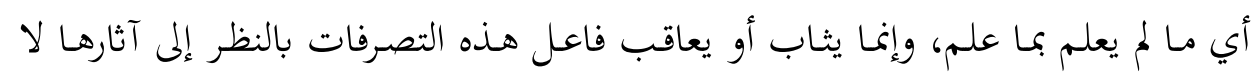
بوزن ذواتها.

$$
60 \text { الأسد آبادي، القاضي عبدالجبار. فضضل الاعتزال وطبقات المعتزلة، مصدر سابق، ص209. }
$$

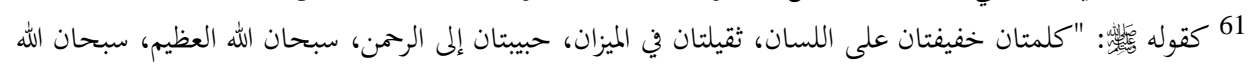

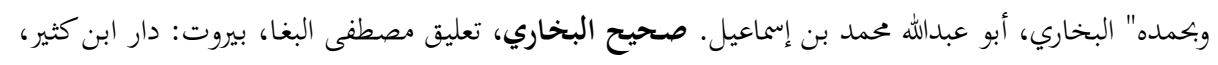

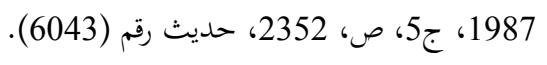

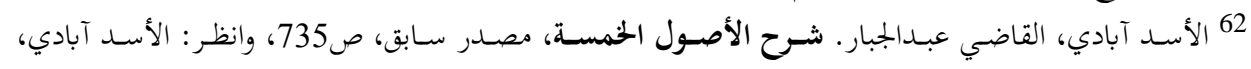

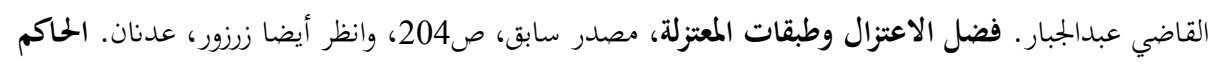

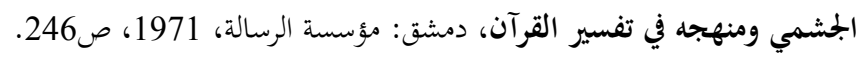




\section{4. قياس الغائب على الشاهد وصلثه بالعقل وبتمثل الموت على هيئة كبش وذبحه:}

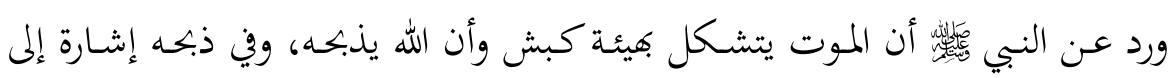

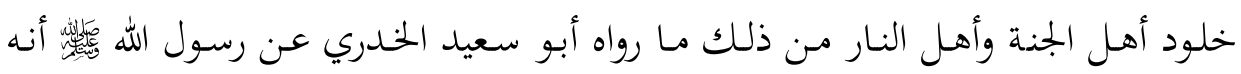

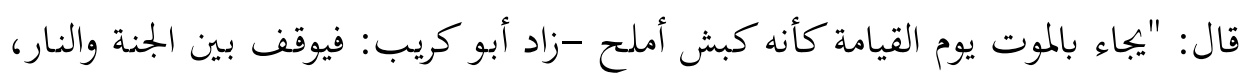

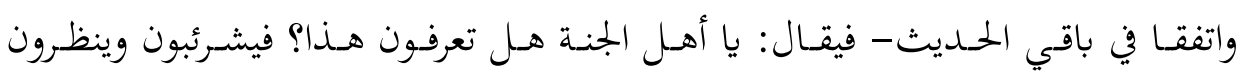

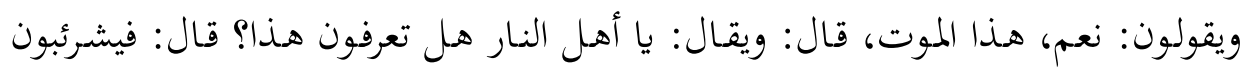

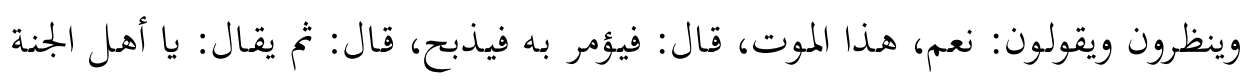

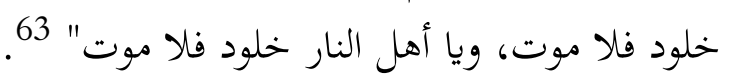

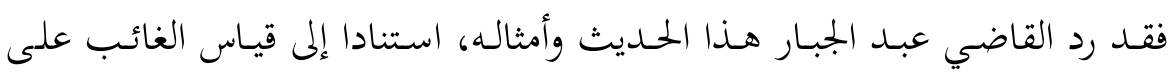

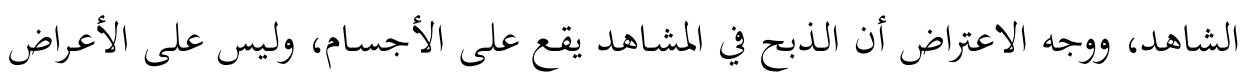

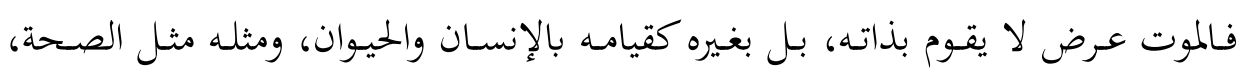

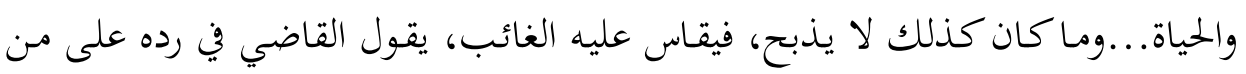

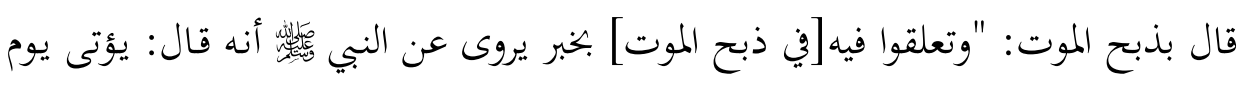

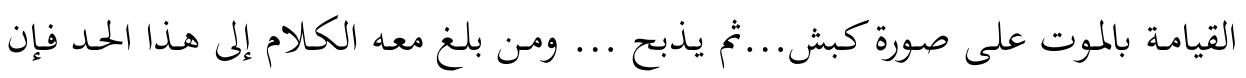

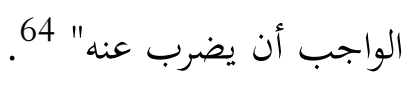

والإضراب عنه، لأن القول بذبح الموت قول غير معقول في نظر القاضي، وفي هذا

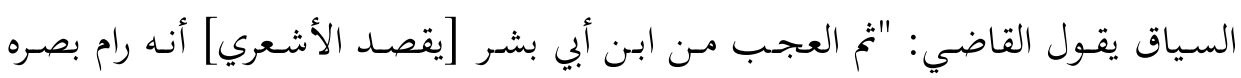

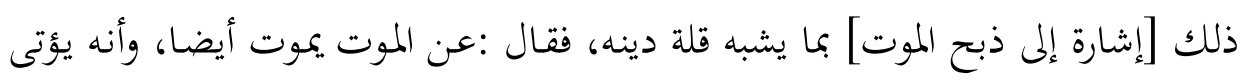

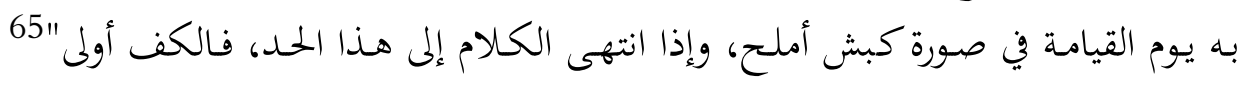

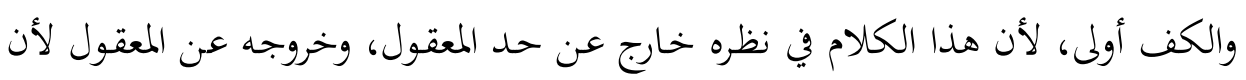

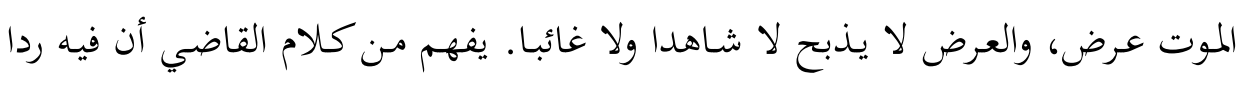

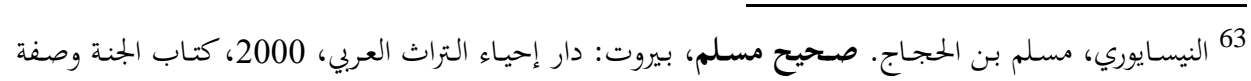

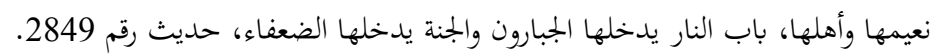

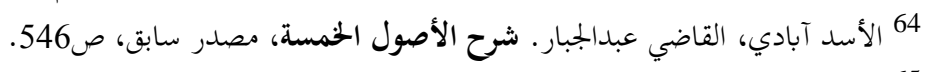

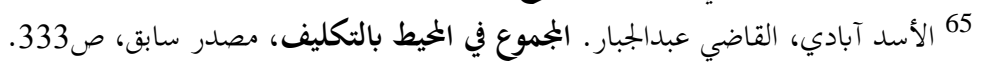




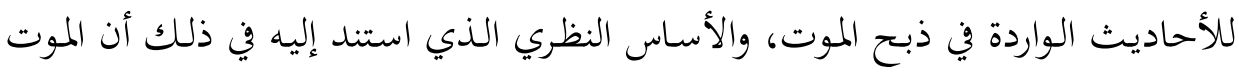

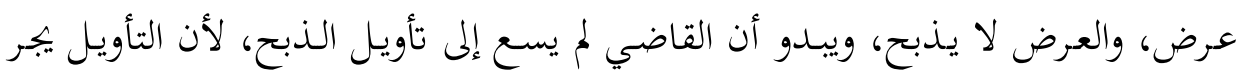

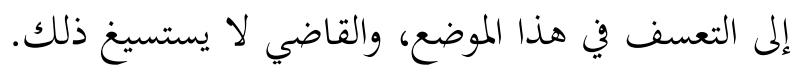

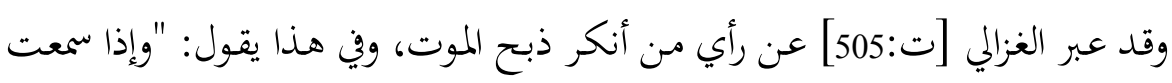

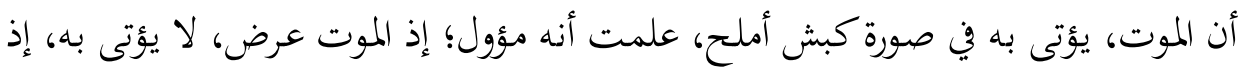

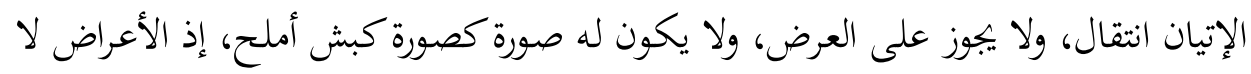

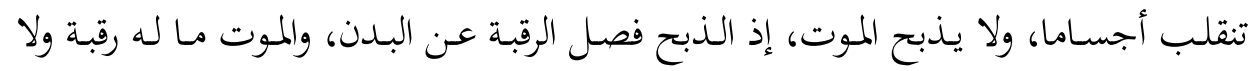

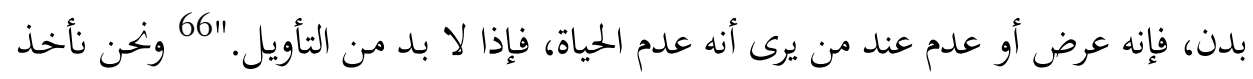

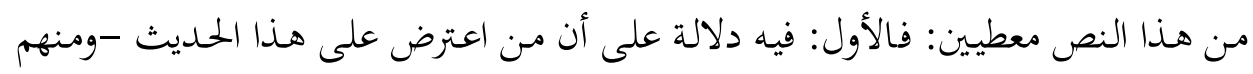

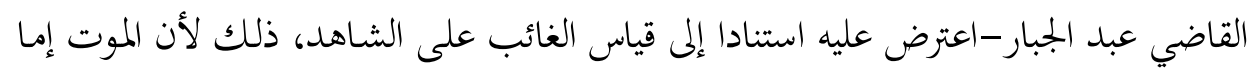

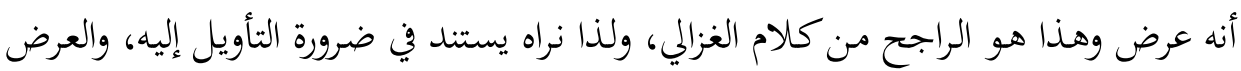

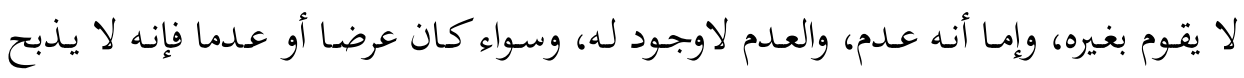

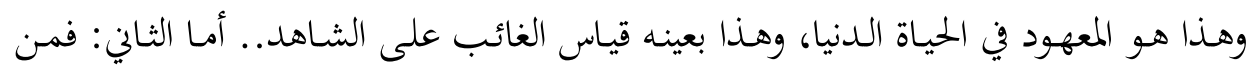

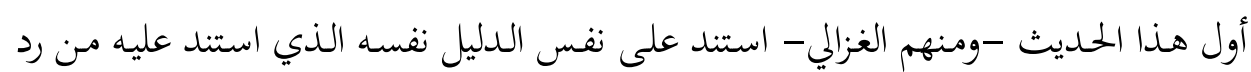

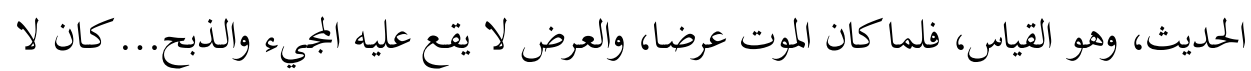

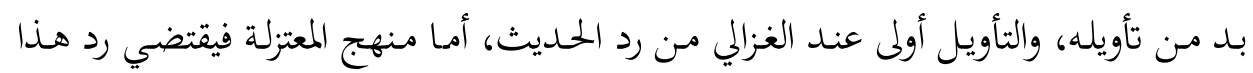

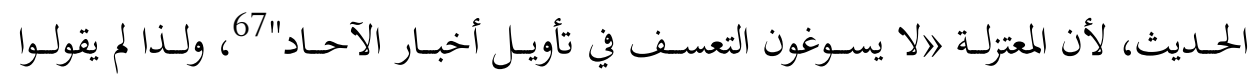

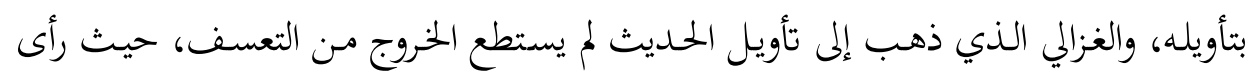

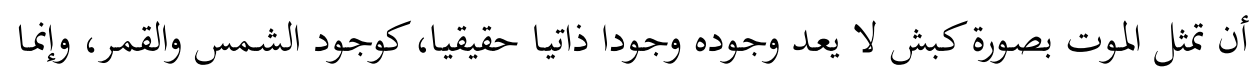
وجوده وجود حسي " يختص به الحاس، ولا يشاركه غيره، وذلك كما يشاهده النائم" 68 ئل

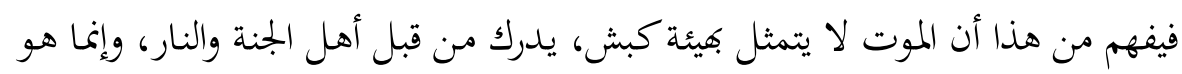

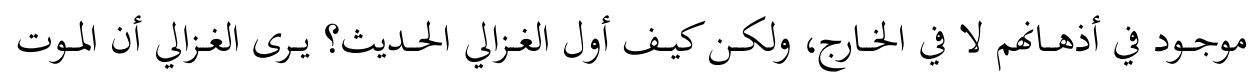

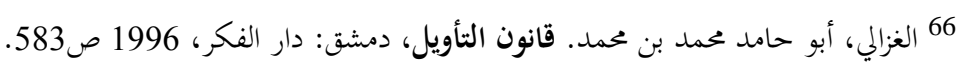

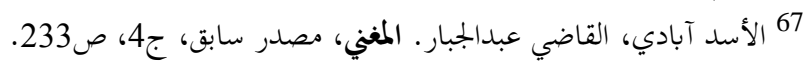
68 الغزالي، أبو حامد محمد بن محمد، فيصل التفرقة بين الإسلام والزندقة، دمشق دارئ صارالفكر، 1996، 1933، ص240. 
بالصورة التي صورها الحمديث يكون "موجودا في حسهم لا في الخارج، ويكون سببا لحصول

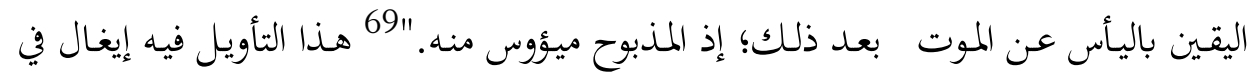

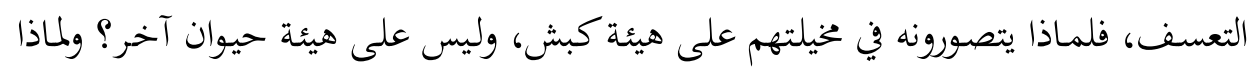

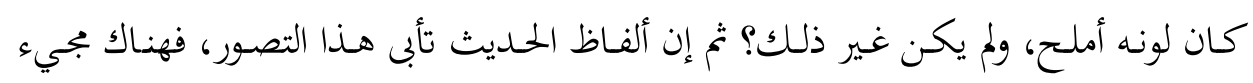

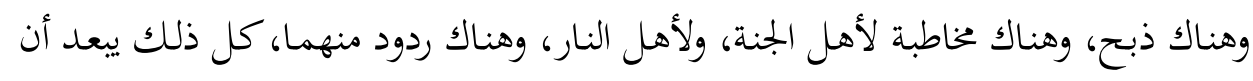

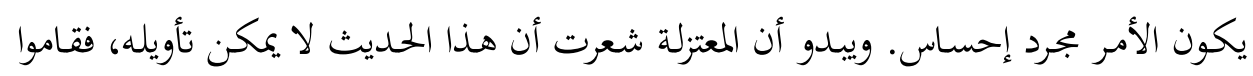

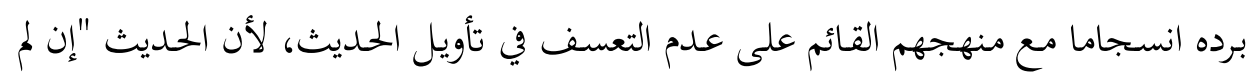

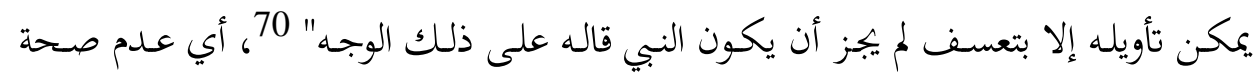

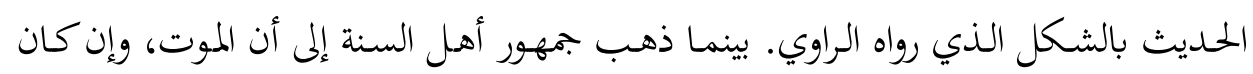

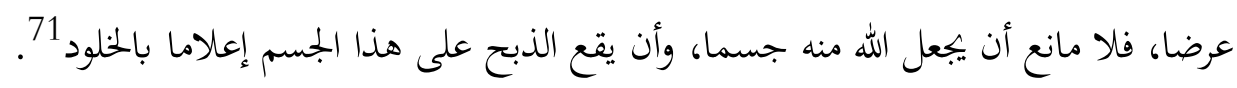

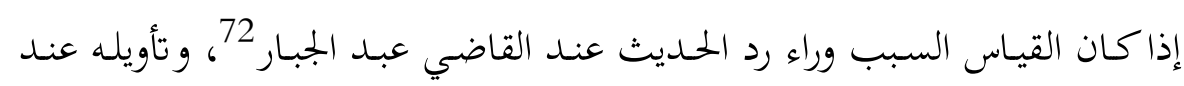

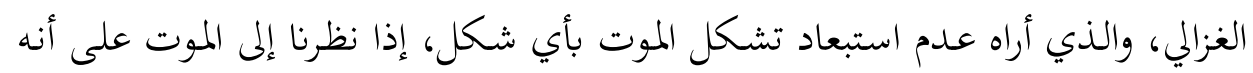

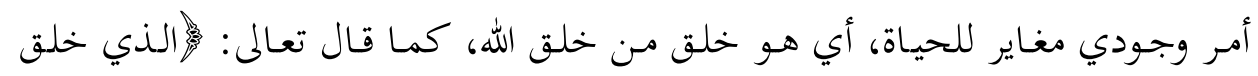

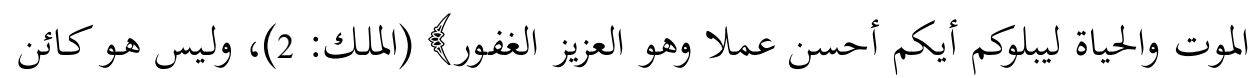

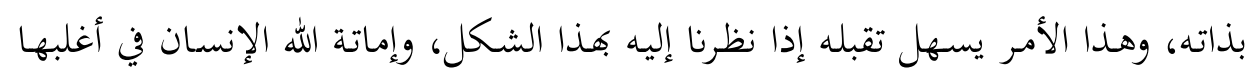

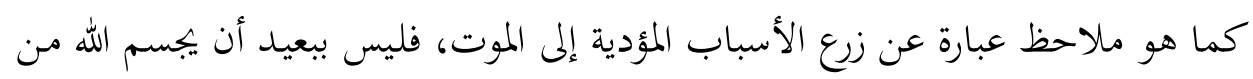

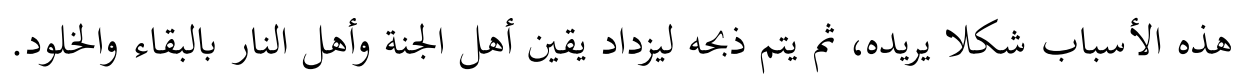

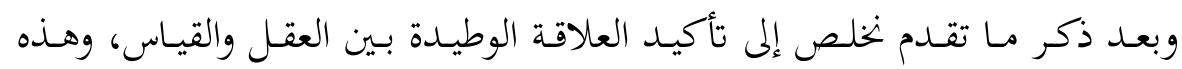

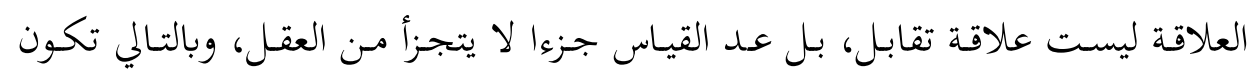

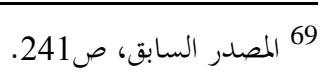

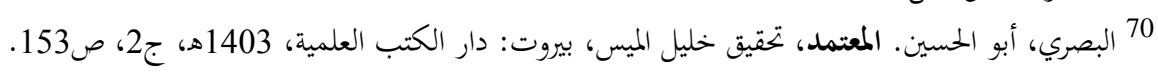

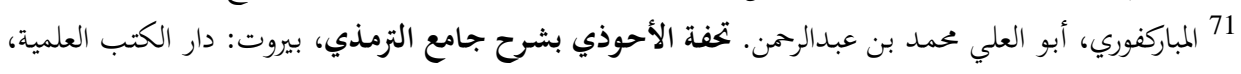

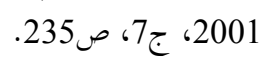

72 بينما اعترف الزخشري بصحة الحديث الوارد في تول الموت إلى كبش، انظر : الزخشري. تفسير الكشاف، مصدر

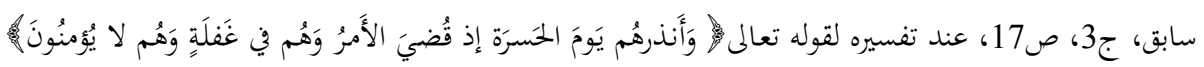


العلاقة بينهما علاقة عموم وخصوص مطلق؛ فالعقل أعم مطلقا من القياس باعتبار أنه

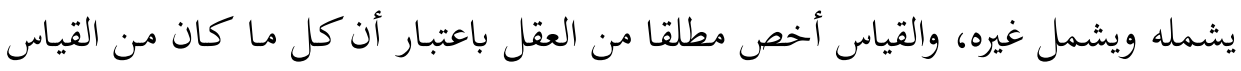

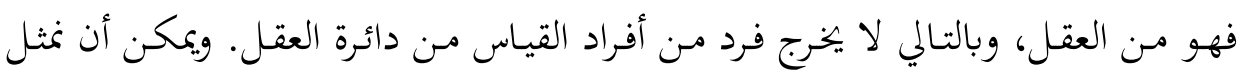

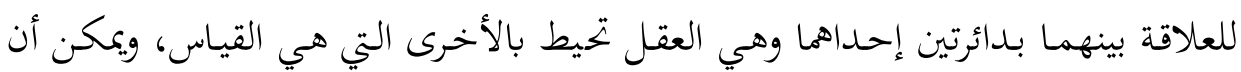
تكون الدائرتان على هذا الشكل:

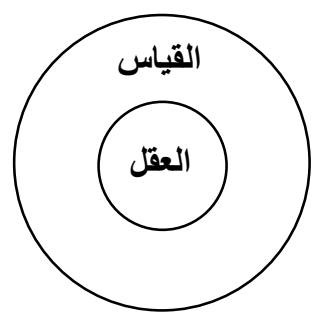

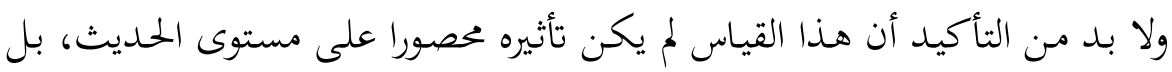

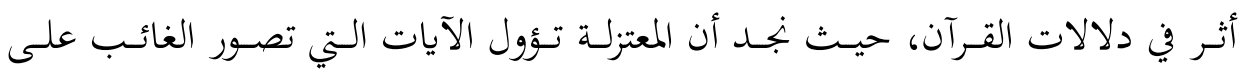

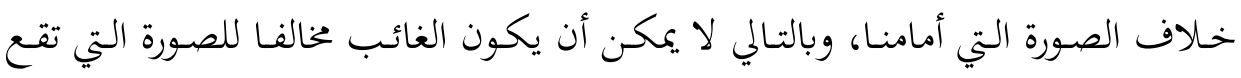

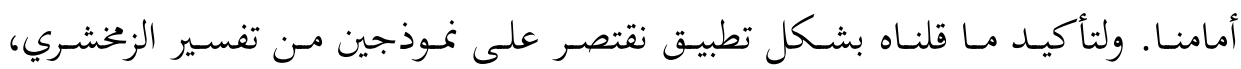

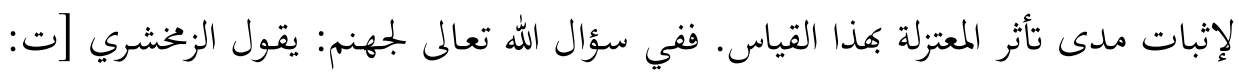

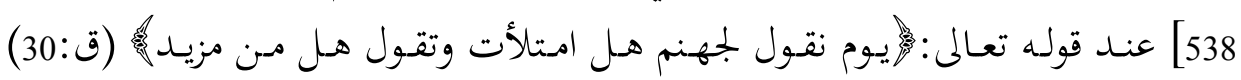

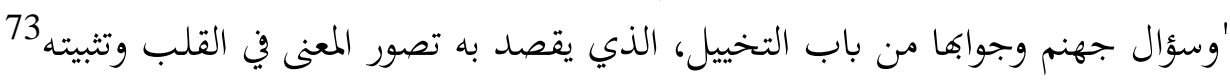

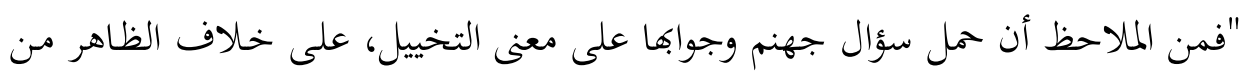

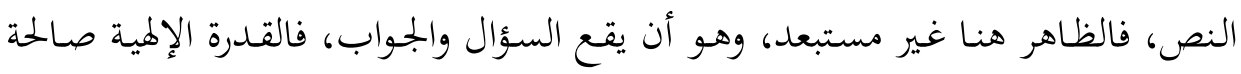

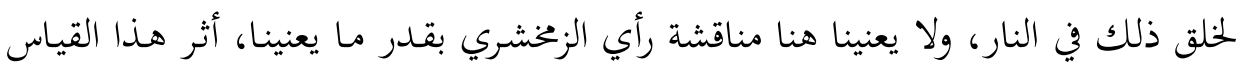

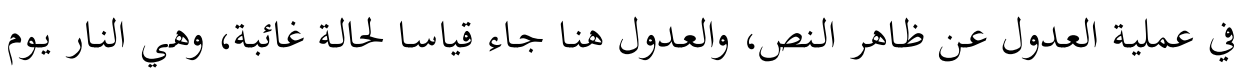

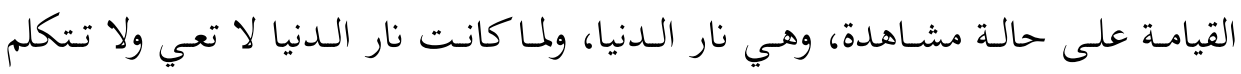


فلتكن كذلك نار الآخرة

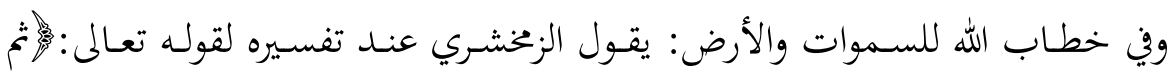

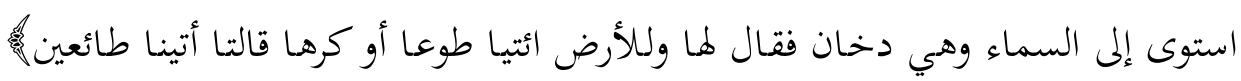

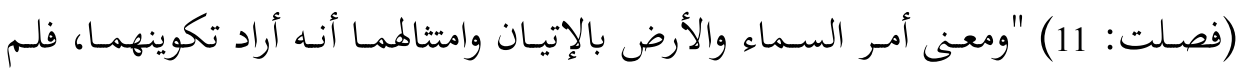

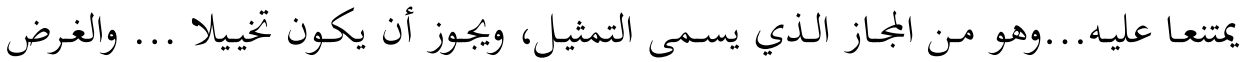

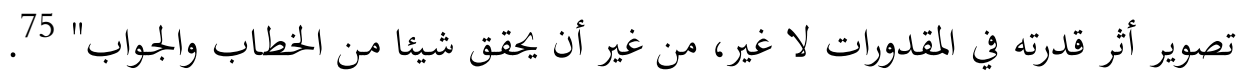
وما قلناه في الآية السابقة ينطبق على هذه الآية.

\section{خامسا: القيمة العلمية لهذا القياس:}

لا بــــ مـن الاعـتراف أنه يستعصي علينـا أن نقـدم تقويمـا علميـا لهـذا القيـاس الـذي

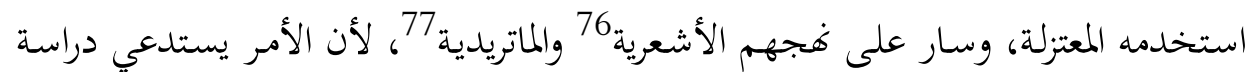

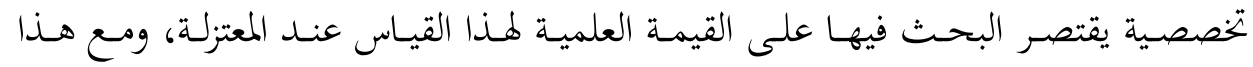

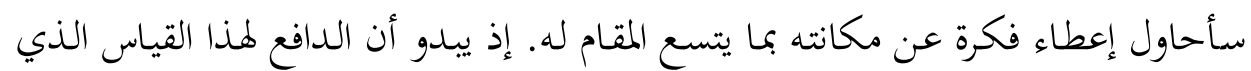

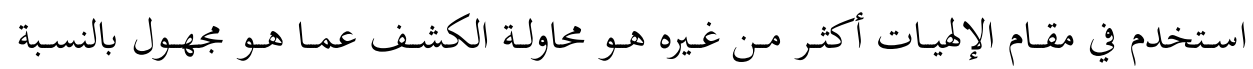

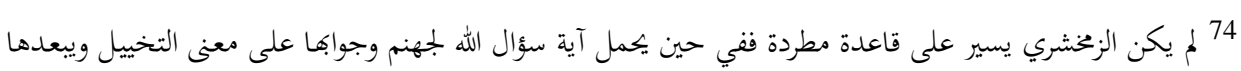

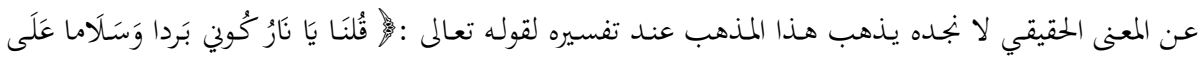

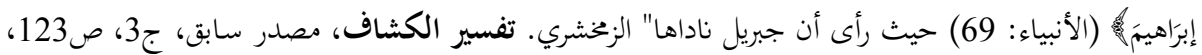

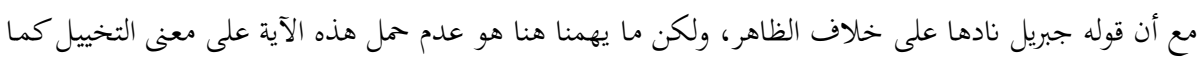

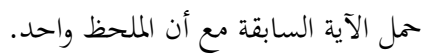

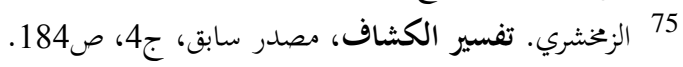

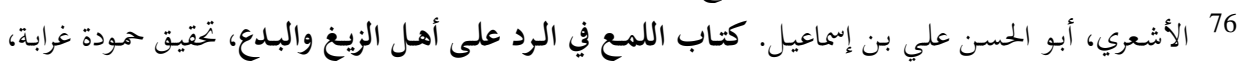

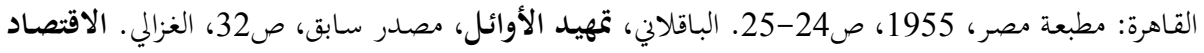

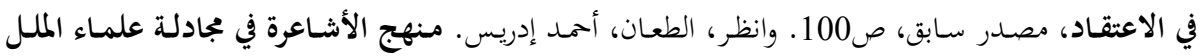

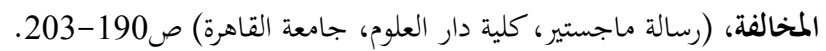

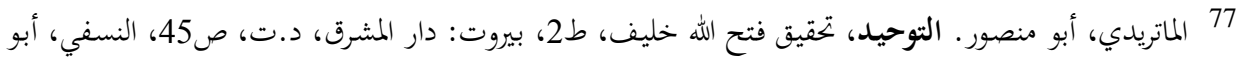

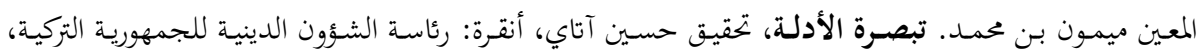

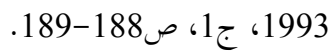


للقائس، وهذا الأمر واضح من خلال تعريفه كما سبق، إذ هو عبارة عن إلحاق ما لم يعلم

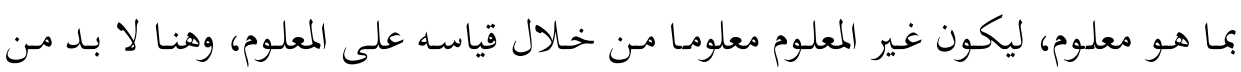
التساؤل: هل هناك داع لمعرفة ما هو بجهول حتى نتعرف بالقياس على على المعلوم؟.

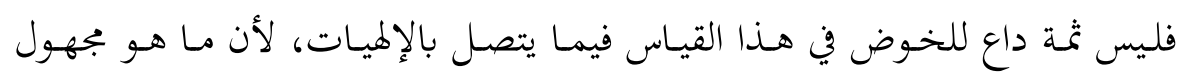

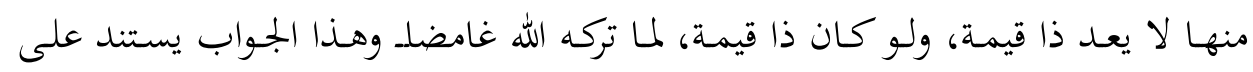

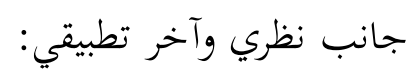

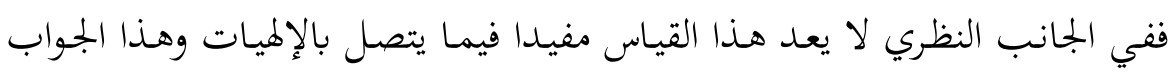

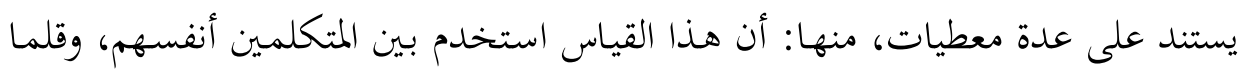

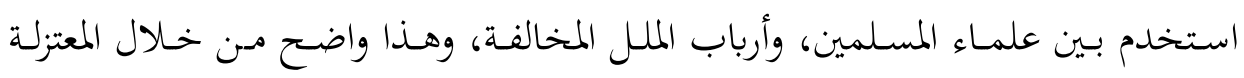

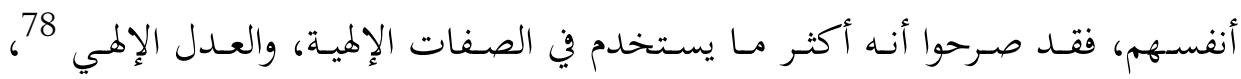

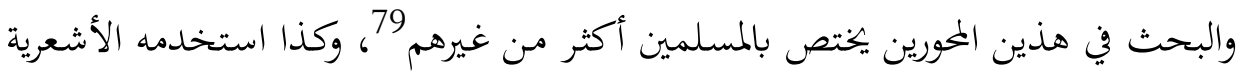

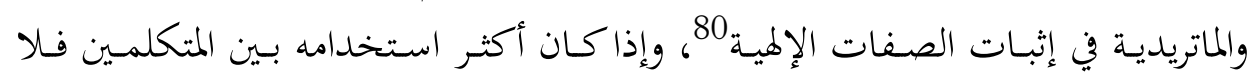

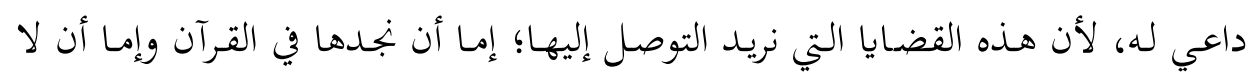

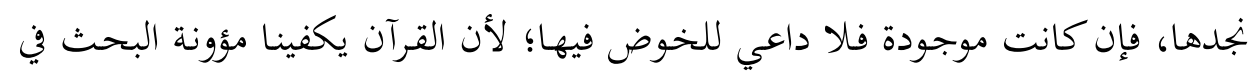

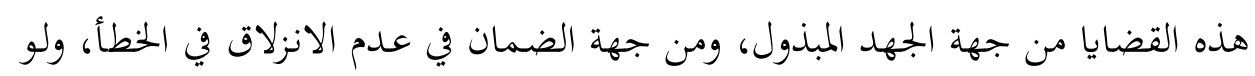

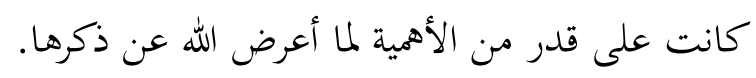

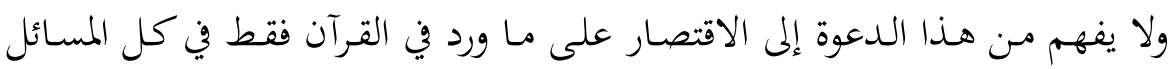

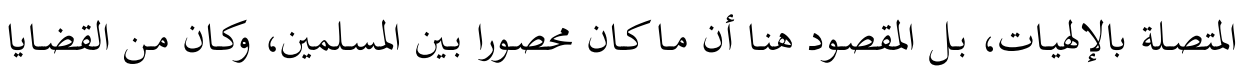

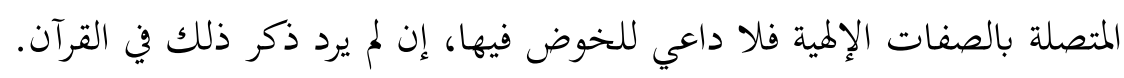

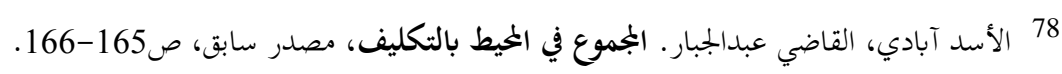

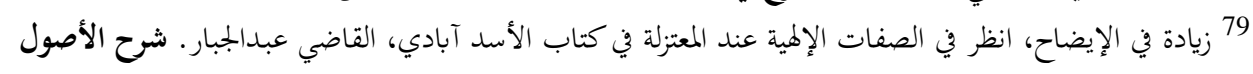

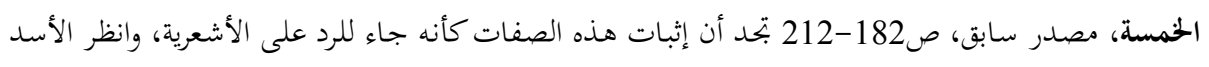

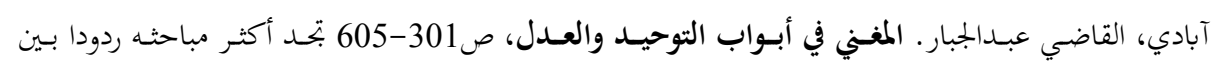
المتكلمين. 80 انظر المصادر الموجودة في حاشية السابقة :رقم:3، 4. 
أمـا المعطى الثـاني: فهـو أنسه أكثـــ الصـفات الإلهيـة وقضـايا العــل التي ذكرهـا

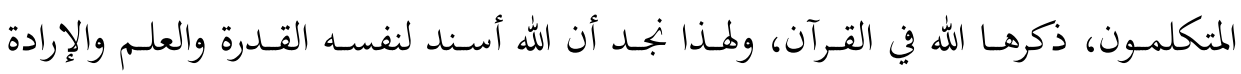
والسمع والبصر والحياة، وهذه هي أبرز الصفات التي حاول المتكلمون إثباتها بالاستناد

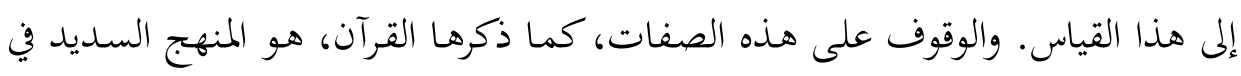

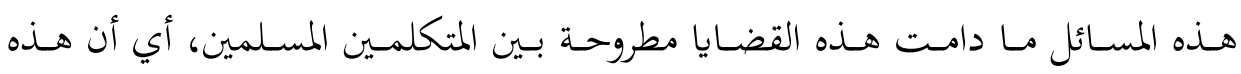

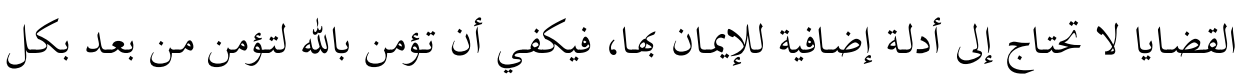

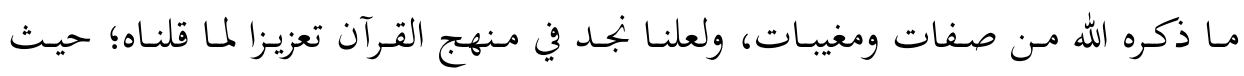
نلحظ أن القرآن عندما يخاطبنا في مسائل غيبية، كوجود الجن والملائكة والجنة والنار، لا والا

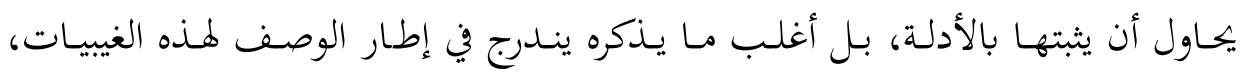
والوصف ليس إثباتا، ويكفي أن نستدل على هذا أن الله تعالى ذكر الجنة أكثر من مائة

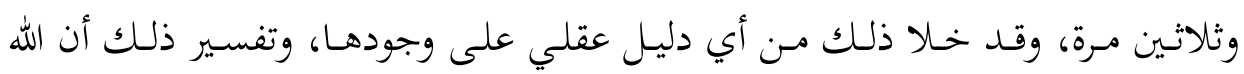

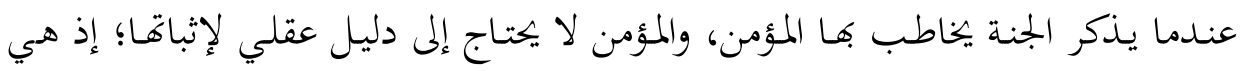

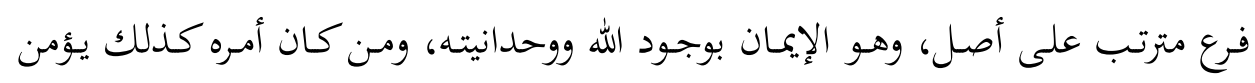

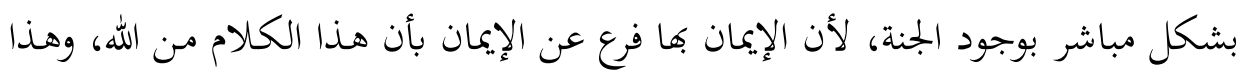

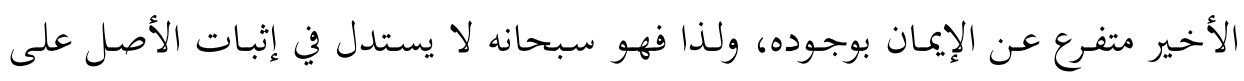

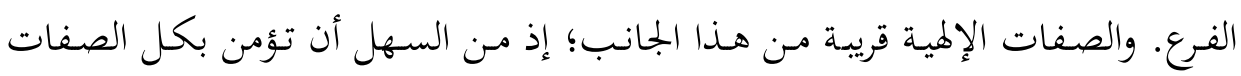

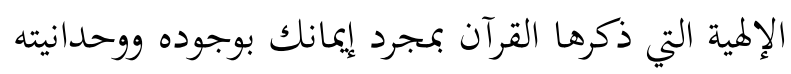

أمـا إن بجـاوزت المسـألة المسـلمين، وأصسبحت القضسية مطروحسة بـين المسـلمين والملـل

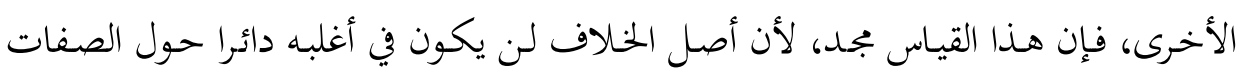

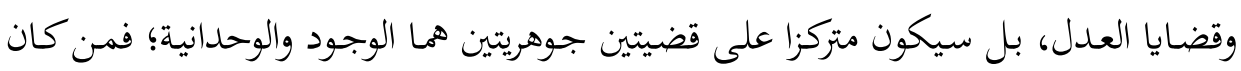

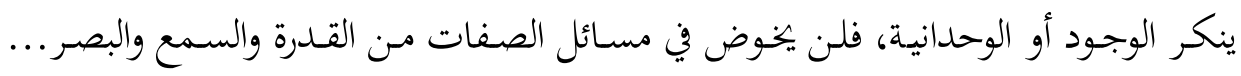

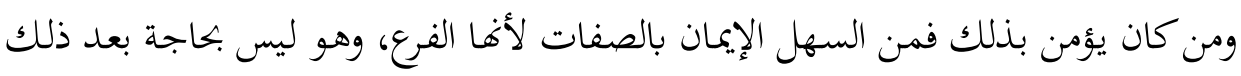

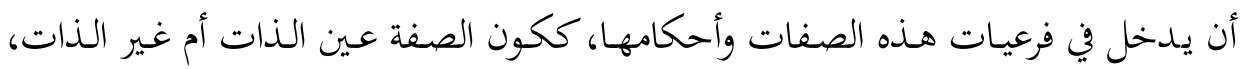

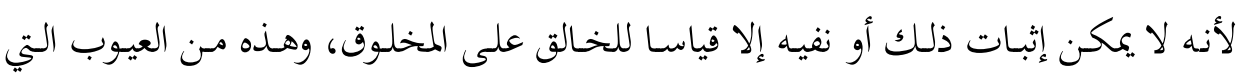
جرها قياس الغائب على الشاهد، والجلدل بين المتكلمين أنفسهم. 


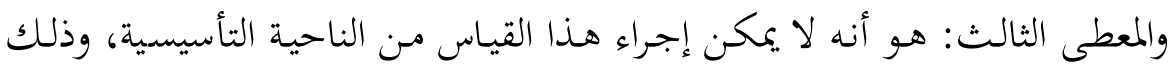

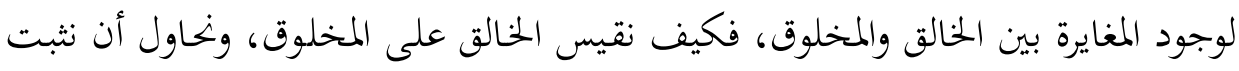

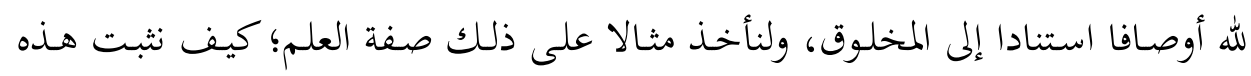

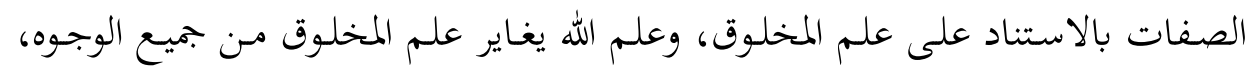

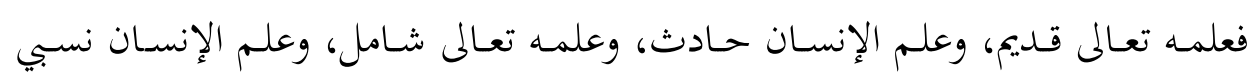

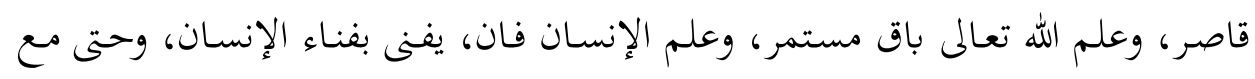

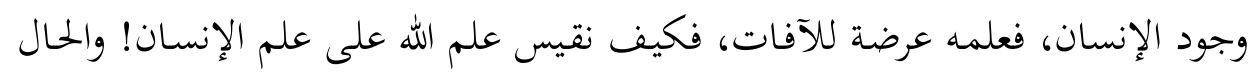

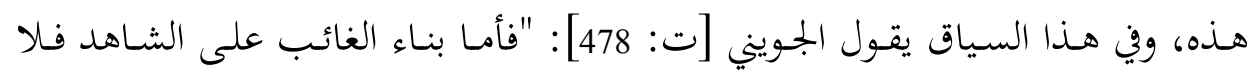

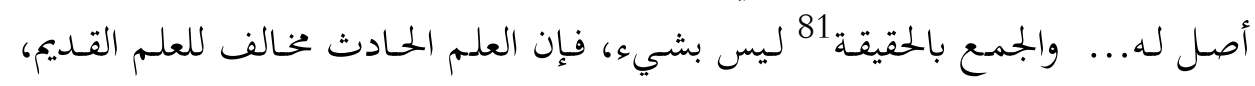
فكيف يجتمعان في الحقيقة مع اختلافهما"

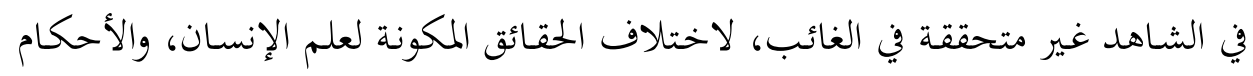

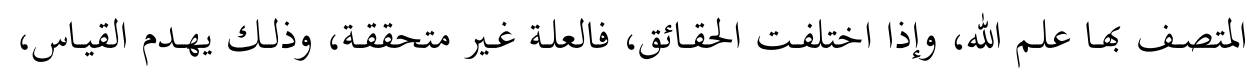

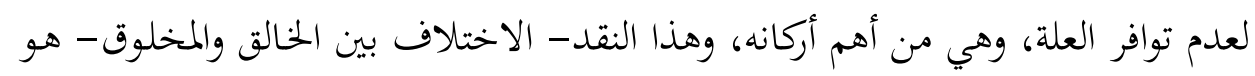

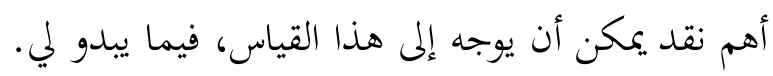

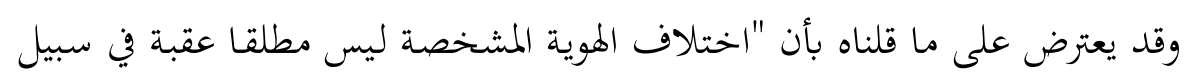

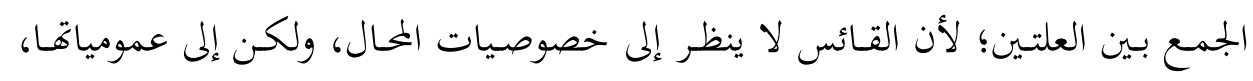

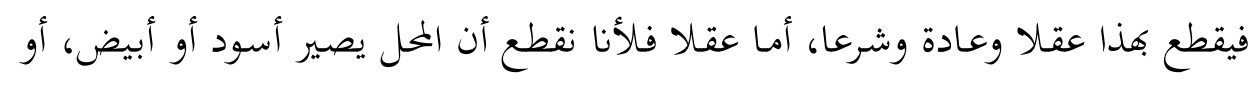

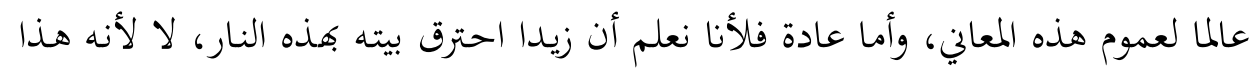

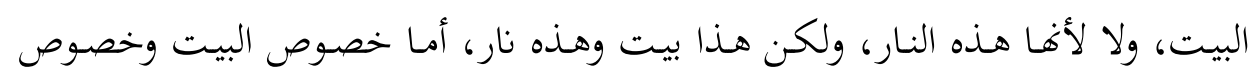

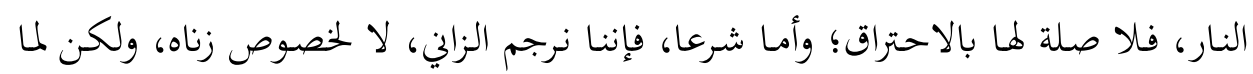

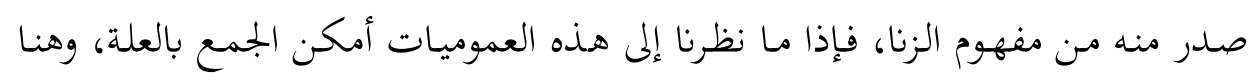

81 8عل الجويني الجمع بين علم الشاهد والغائب بحامع الحتيقة، وهذه مسألة غير متفقِ عليها، ولذا فإن الغزالي يجعل

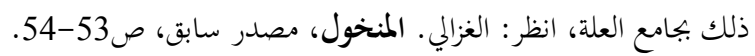
82 الجوبيني، ركن الدين أبو المعالي عبدالملك. البرهان في أصول الفقهه، القاهرة: دار الأنصار، 1980، ج1، ص106. 
يصل الباحث إلى درجة اليقين"83.

وخلاصة هذا الاعتراض أن الجمع بين الشاهد والغائب لا ينظر فيه إلى خصوصيات

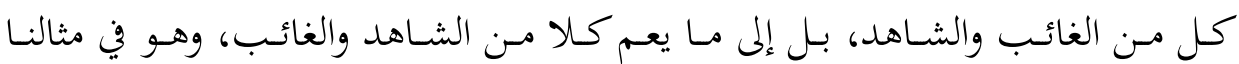
السابق، مطلق العلم دون النظر إلى خصوصيات علم الله من أقدمية وشمولية وبقاء إذا مـا

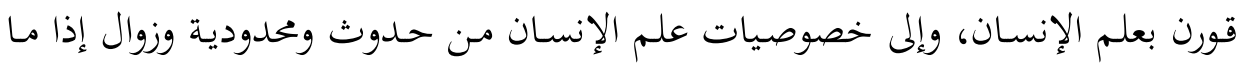

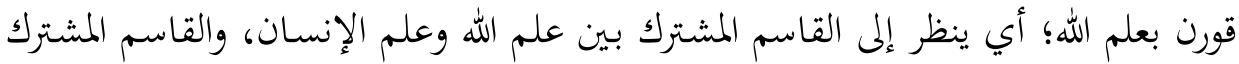

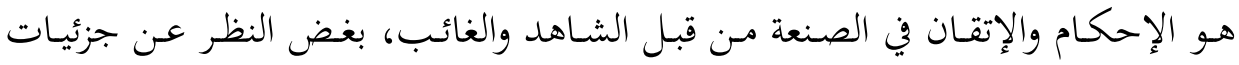

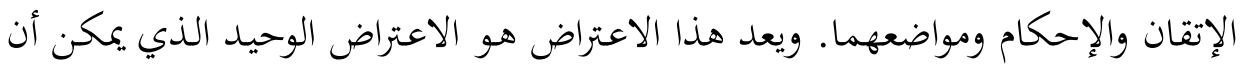

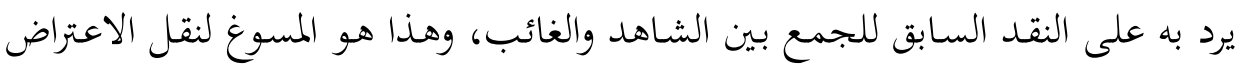

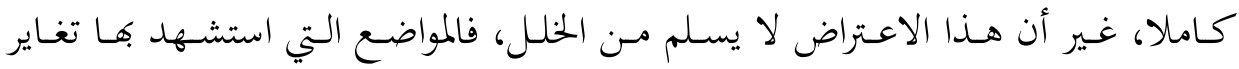

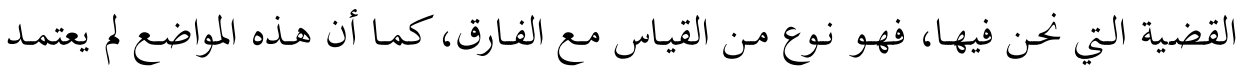

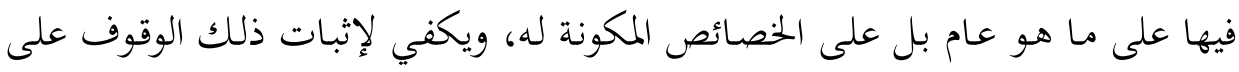
بعض الأمثلة التي ساقها المعترض.

فنفي خصوصية النـار والبيت في عملية الإحراق، والوقوف عند مسـمى النـار ليس

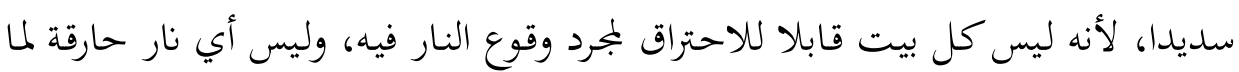

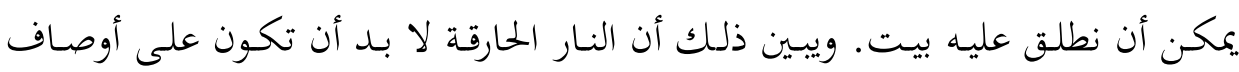

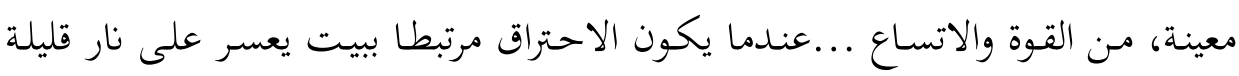

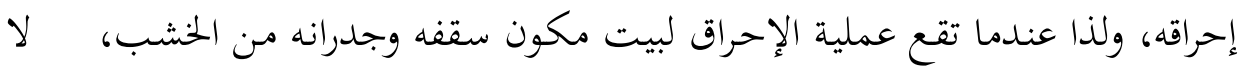

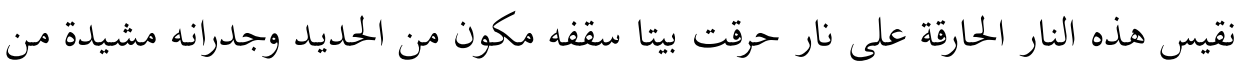

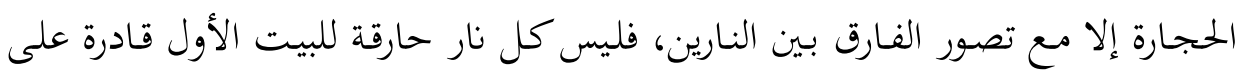
إحراق البيت الثاني.

ومثل ذلك الزنا، فلا يقع الجلد أو الرجم إلا ضمن شروط معينة، بل إن مفهوم الزنا

83 المرشد، يعبد العزيز عبد اللطيف. قياس الغائب على الشاهد في الفكر الإسلامي، (رسالة دكتوراه، كلية أصول

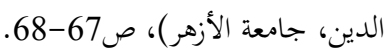


نفسه لا يقع إلا مع توافر شروط معينة، ولهذا قد نجلد الزانيين، وقد نجلد الرجل فقط إذا

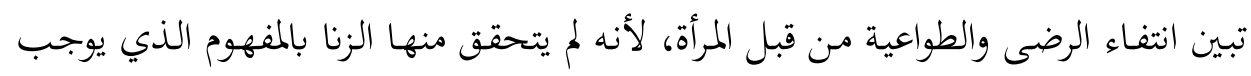

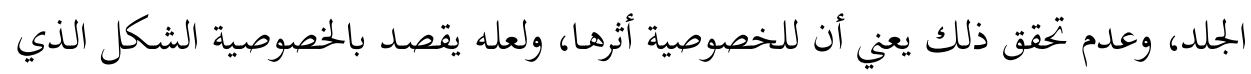

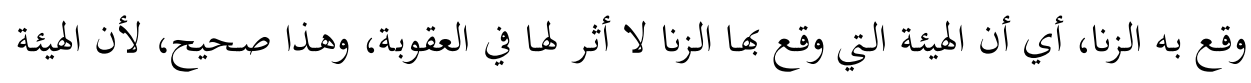

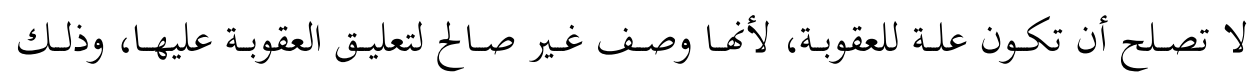

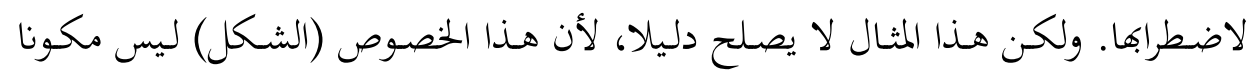

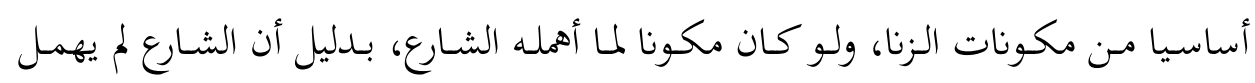

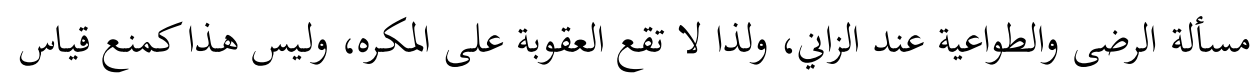

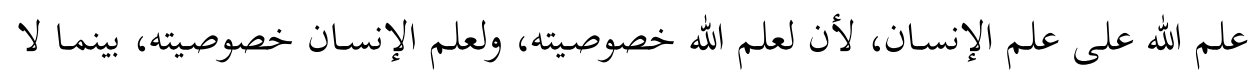

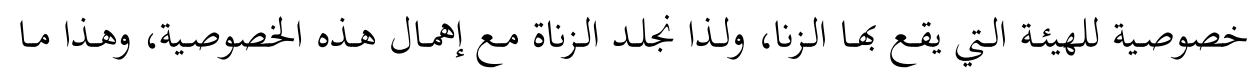
قصدته بالقياس مع الفارق.

أما في الجانب التطبيقي فلا يمكن تطبيق هذا القياس في الجانب الإلهي، وذلك لعدم

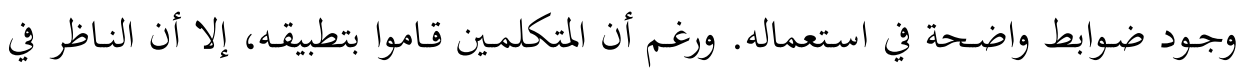

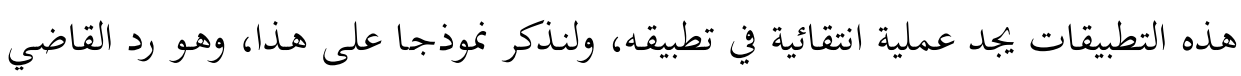

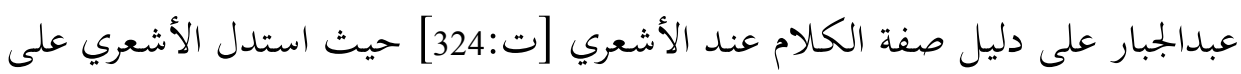

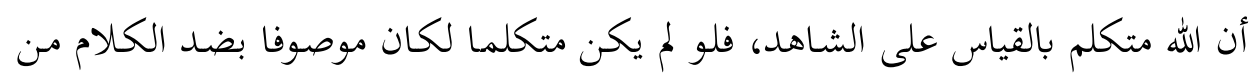

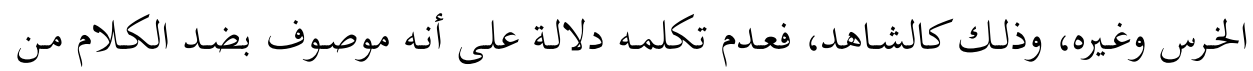

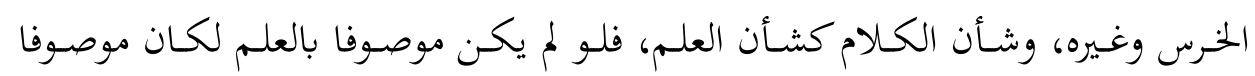

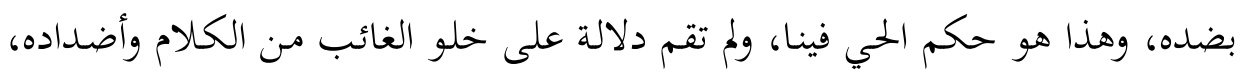

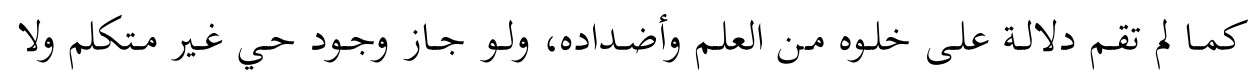

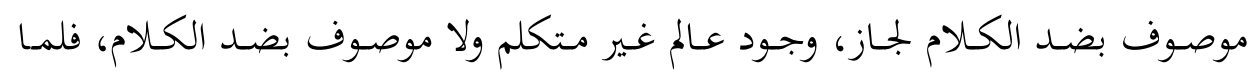

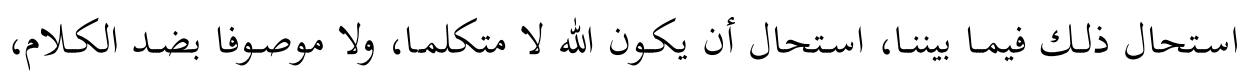


وإذا استحال ذلك وجب أن يكون الله متكلما.84 ومن الواضح أن دليل الأشعري عبارة عن إلحاق الغائب بالشاهد، وقد ذكر القاضي

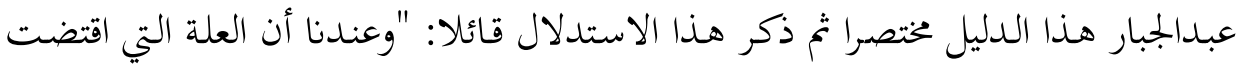

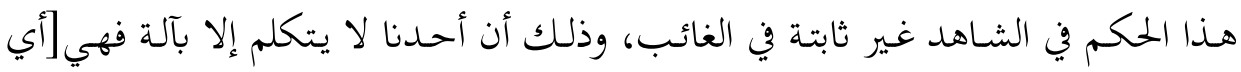

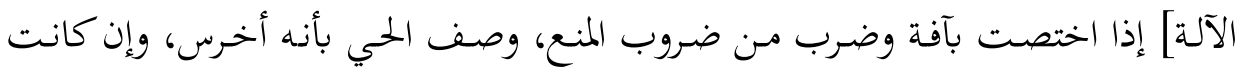

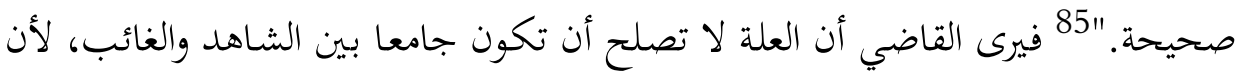

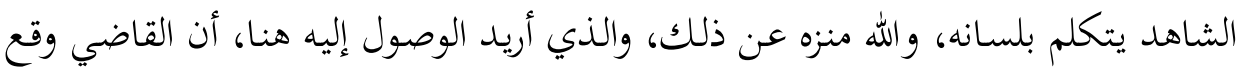

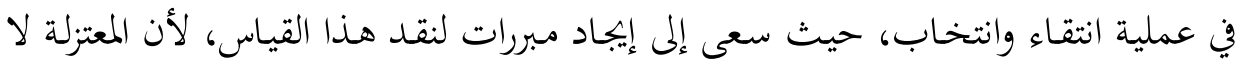

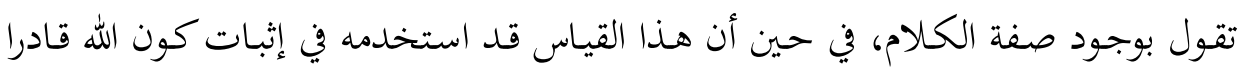

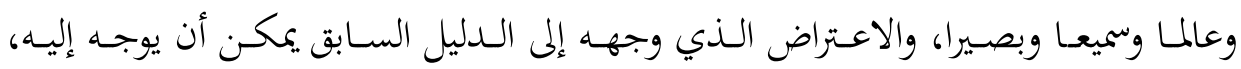

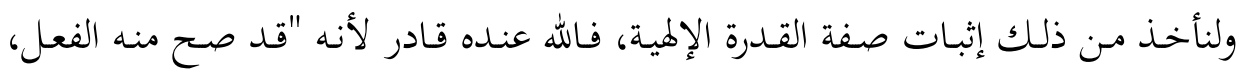

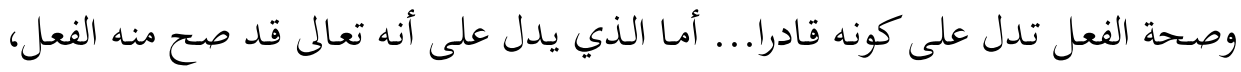

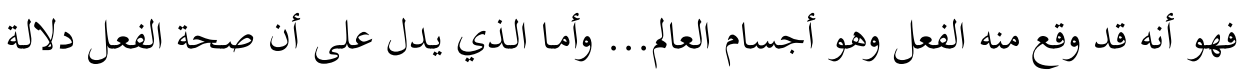

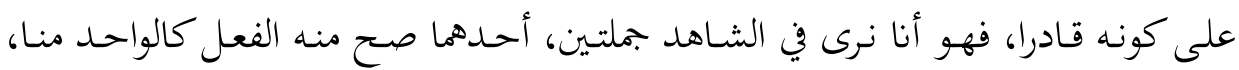

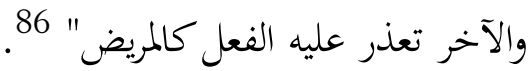

والنـاظر في هـذا النص لا يجـد تفرقة بين هـذا الاستـلال لإثبـات كـون الله قادرا، وبين

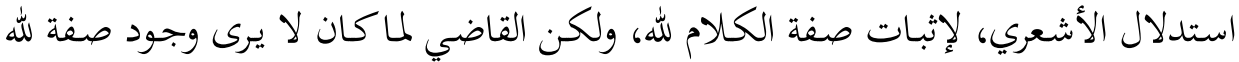

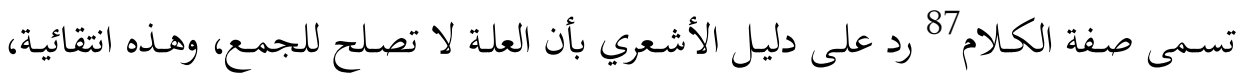

84 الأشعري. اللمع، مصدر سابق، ص36-37. وبهذا استدل أبو منصور الماتريدي، انظر، الماتريدي، أبو منصور.

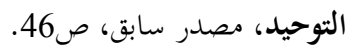

85 الأسد آبادي، القاضي عبدا الجبار . الجمموع في الخحيط بالتكليف، مصدر سابق، ص349.

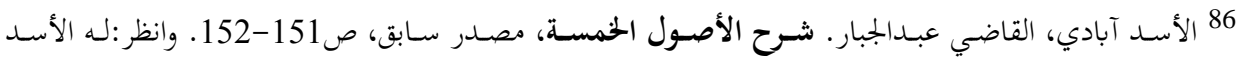

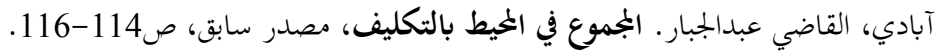

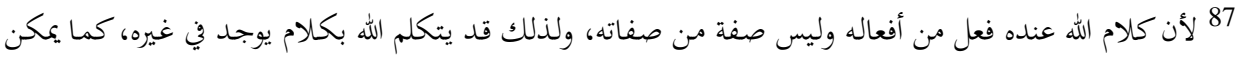

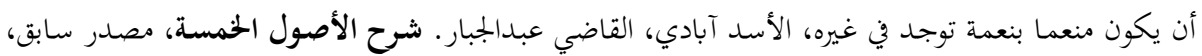


لأن الاعتراض الذي اعترض به على الأشعري يرد عليه؛ إذيمكن أن يقال له إن العلة التي

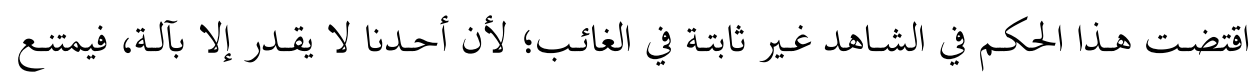

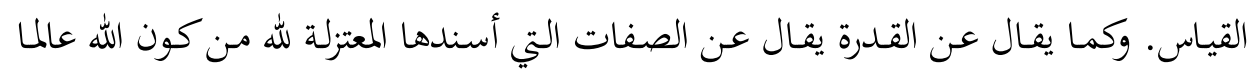

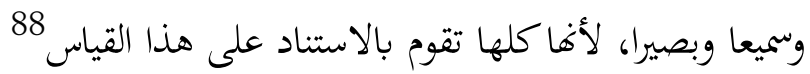

وزيادة على هذا الانتقاء فإن هذا التطبيق جر المتكلمين إلى تصورات عجيبة جعلت

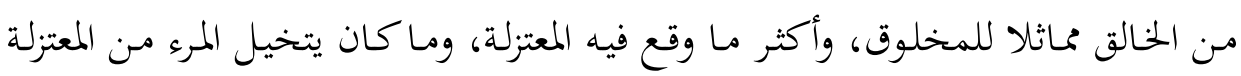

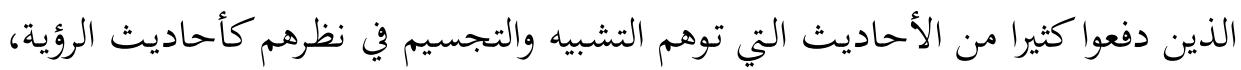

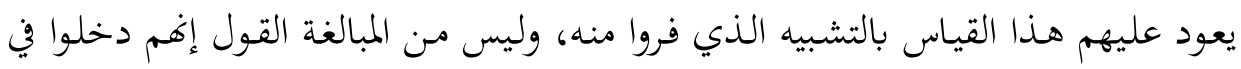

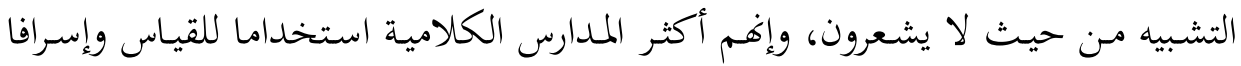

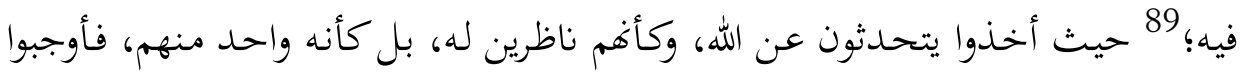

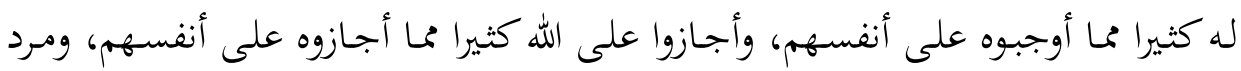
ذلك إلى الثقة المطلقة بهذا المنهج. وهذا المنهج - كما قادهم إلى نوع من المشابهة- فقد جرهم إلى الحد من صلاحية هذا الإله وقدرته، وهذا نتيجة القياس على المخلوق الضعيف المحدود القدرة. ونكتفي بـذكر بعض النماذج التي جرها هذا القياس، التي جعلت المعتزلة يصورون

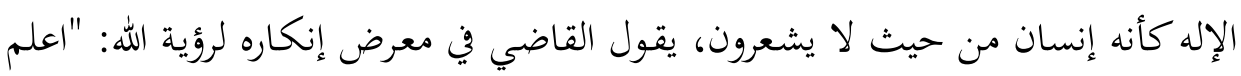

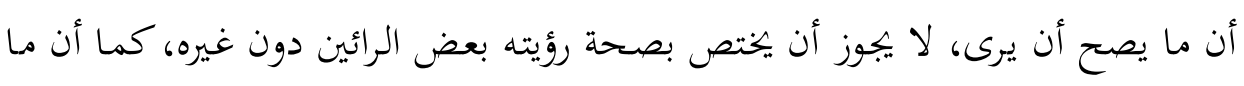

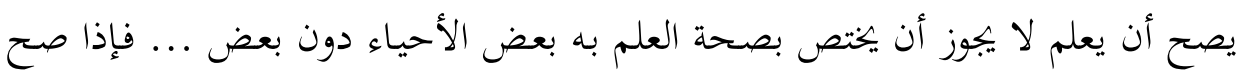

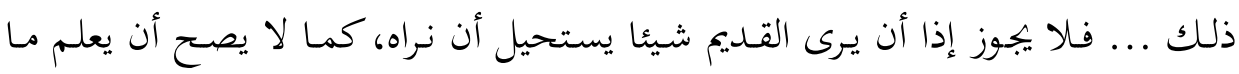

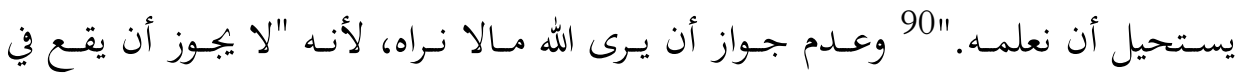

88 الأسـد آبادي. شـرح الأصسول الخمسـة، مصدر سابق، ص157-158، 168. وانظر، الأسـد آبادي، القاضي

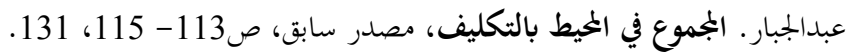

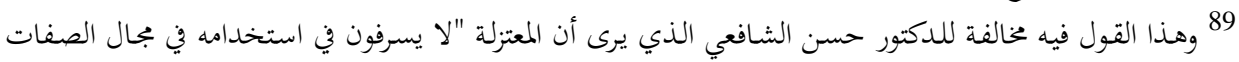

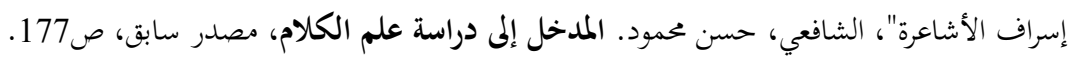

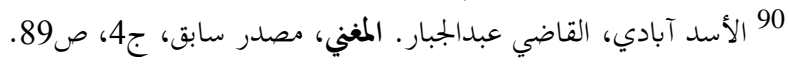




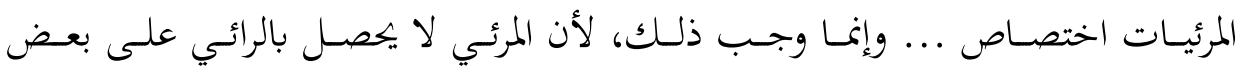

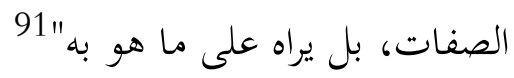

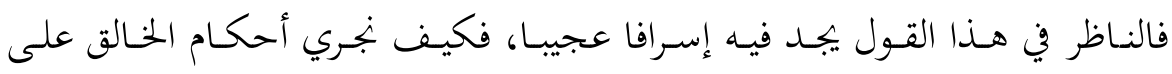

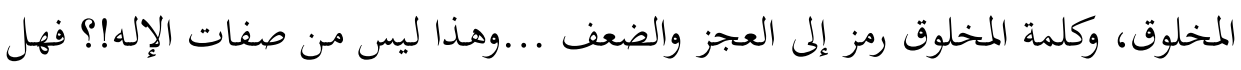

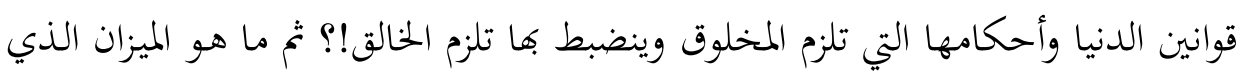

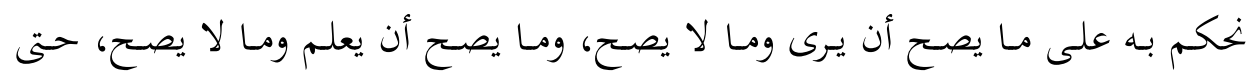

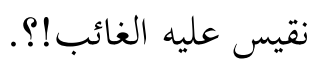

ثم ما الدليل على أنه ليس هناك اختصاص في المرئيات؟!، أليس من الممكن أن يرى

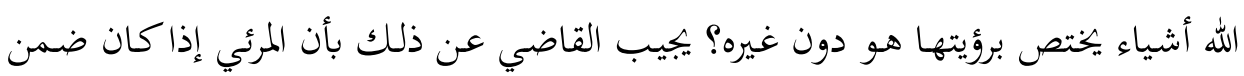

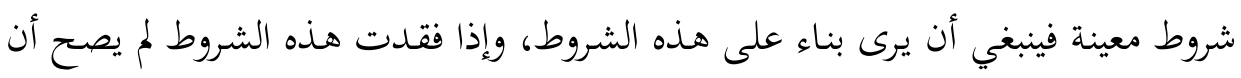

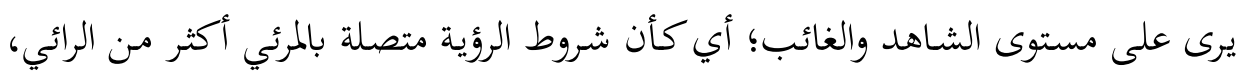

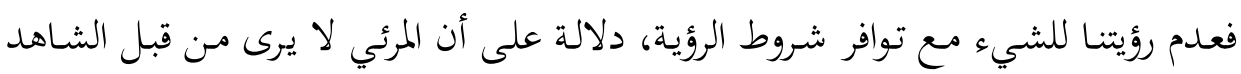

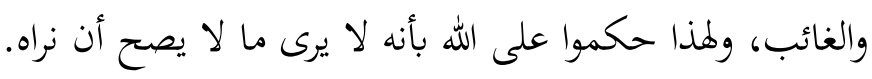

وقد رتبوا على هذه المسألة مسألة أخرى، وهي عدم جواز رؤية الله لنفسه، وهذا

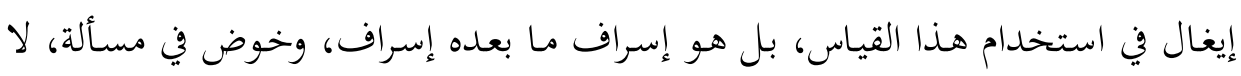

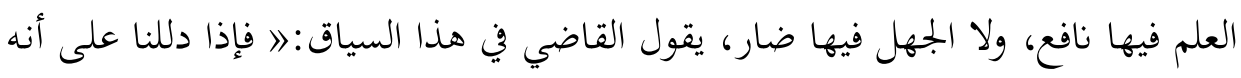

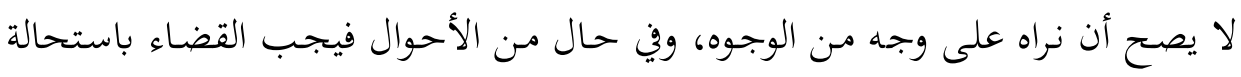

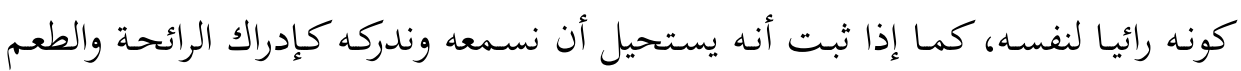

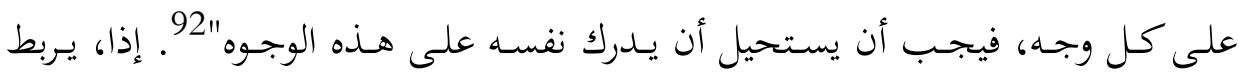

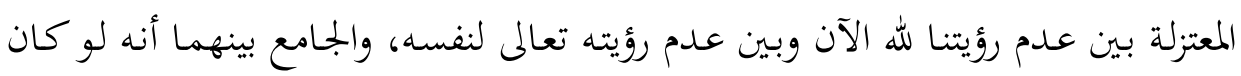

$$
91 \text { المصدر السابق، ج4، ص89. }
$$

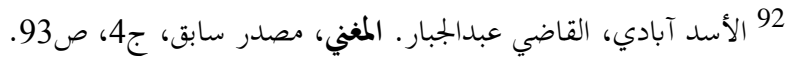


يرى لرأيناه إذا ارتفعت الموانع المانعة من الرؤية كالبعد والحجاب ... 93، والموانع مرتفعة؛ لذا لا يصح أن ندعي عدم رؤيته بواحدة من الموانع كالبعد أو وجود آفة في العين ... 94

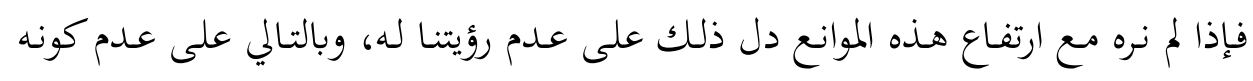
رائيا لنفسه.

لكن لماذا رتب المعتزلة على عدم رؤيتنا له تعالى أنه لا يرى نفسه، أي ألا يمكن أن

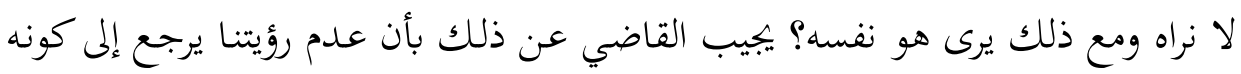

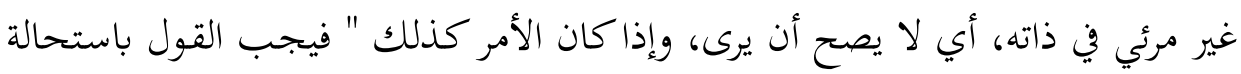

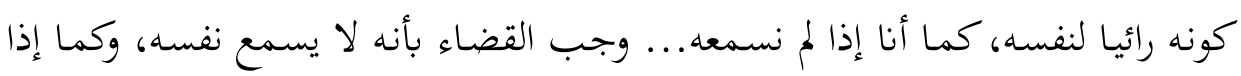
لم نر المعدوم لعدمه، وجب القضاء بأنه تعالى لا يجيوز أن نراه" هـذا النص يرجعنـا إلى القاعـدة السـابقة التي ذكرهـا المعتزلة، وهي المسـاواة بين الغائب

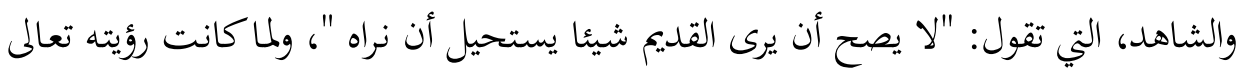

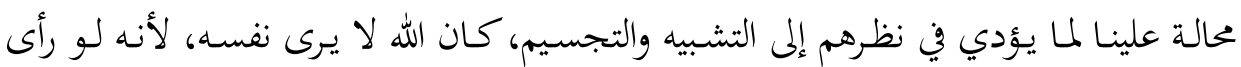

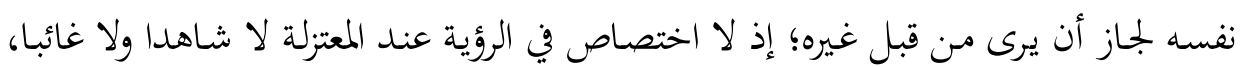

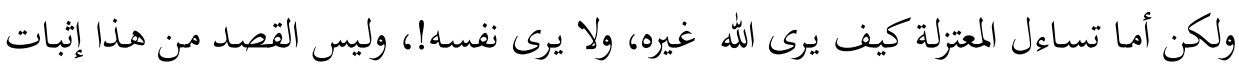

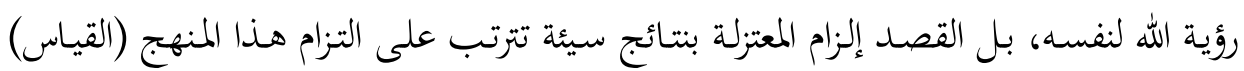

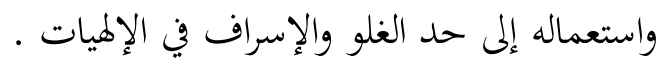

يضاف إلى مـا تقدم عـدم انسجام أغلب الأشعرية مع أنفسهم في التعامل مع هـا

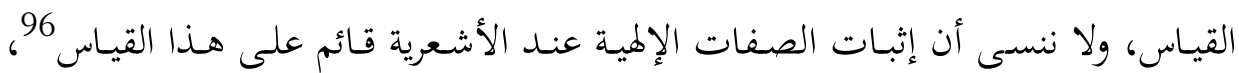

$$
\begin{aligned}
& 93 \text { المصدر السابق، ج4، ص116. }
\end{aligned}
$$

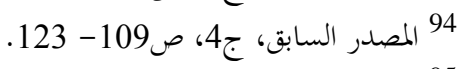

$$
\begin{aligned}
& 95 \text { المصدر السابق، ج4، صوب، ص95. }
\end{aligned}
$$

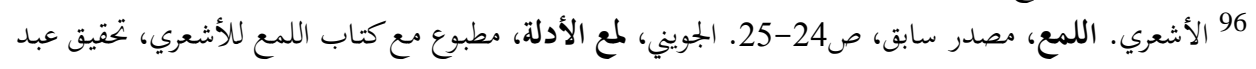

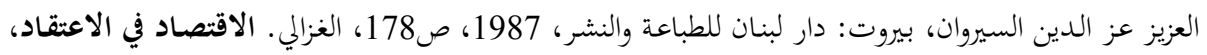

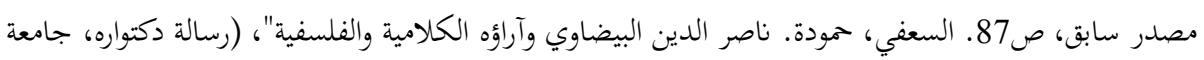

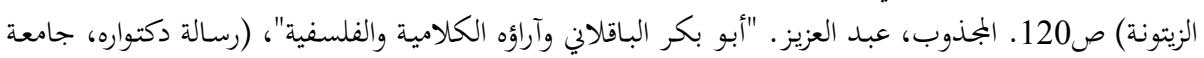

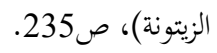


وعدم الانسجام يدل على وجود مأزق فكري في التعامل مع هذا القياس، وهو مـا يعد

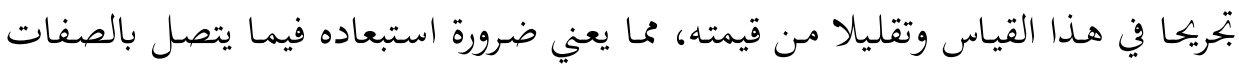

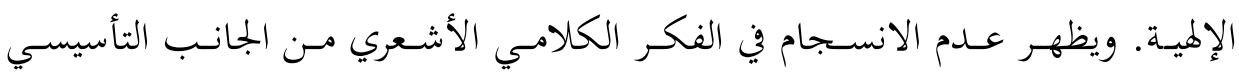

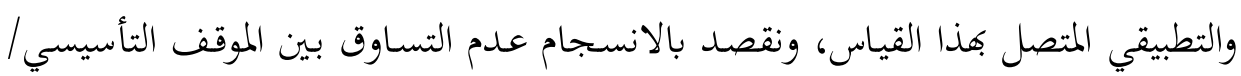
النظري والموقف التطبيقي العملي، أي أفم رفضوا القياس من الناحية التأسيسية، ولكنهم عجزوا عن التخلي عنه من الناحية التطبيقية.

فمن الناحية التأسيسية نجد كثيرا من الأشعرية المتأخرين رفضوا هذا القياس، لأنه لا

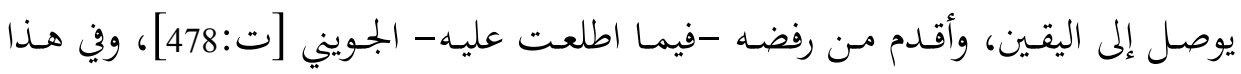

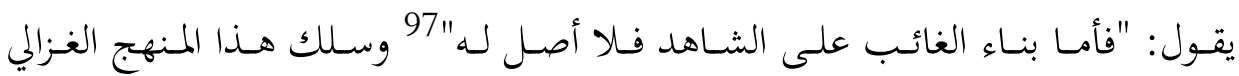

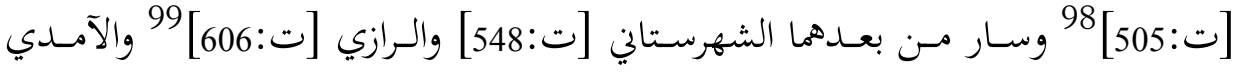
[ت:631]، 100 بينما قبله كل الأشعرية من الناحية التطبيقية سوى الآمدي 101 وعلى هذا

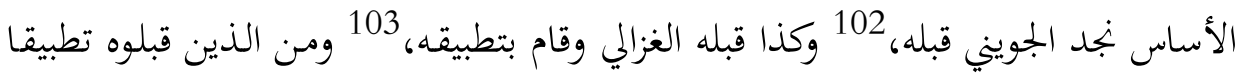

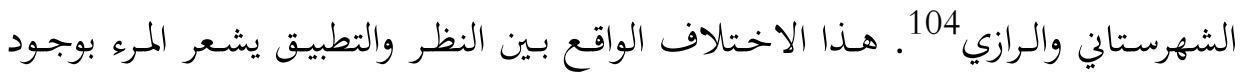

$$
\text { } 97 \text { الجويني. البرهان في أصول الفقه، مصدر سابق، ج1، ص106. }
$$

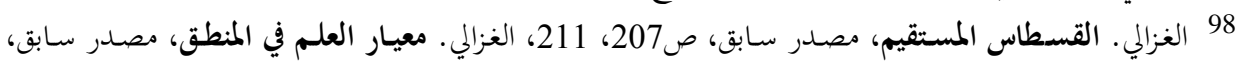

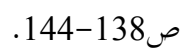

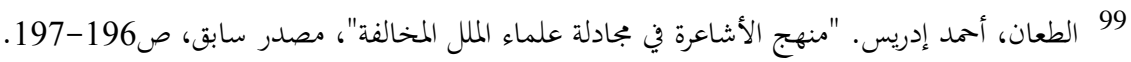

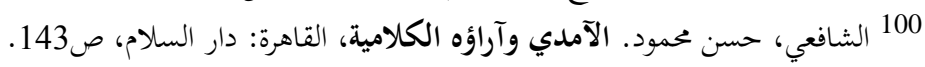

$$
101
$$

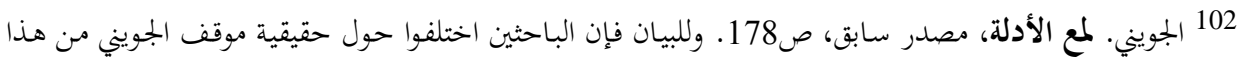

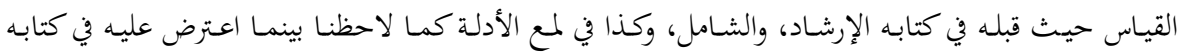

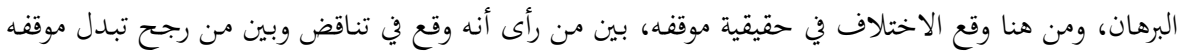

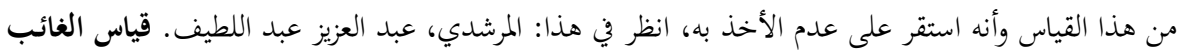

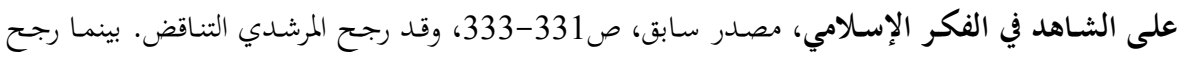

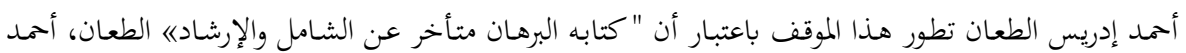

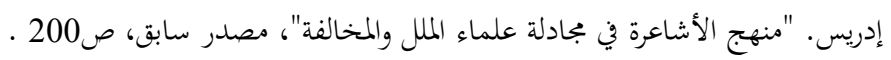

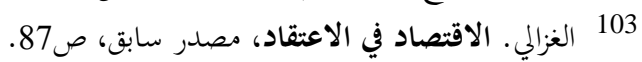

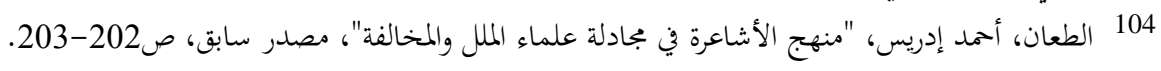


مأزق في هذا القياس لدى الأشعرية، وهو ما يومئ إلى عدم اطمئناغم له.

\section{الحاتمة}

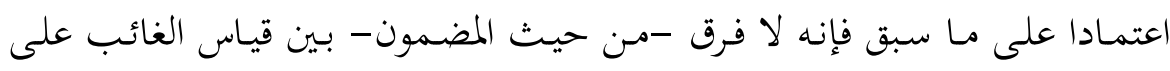

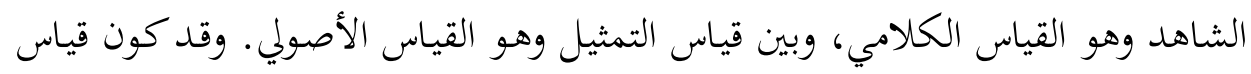

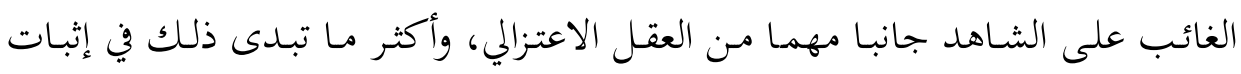

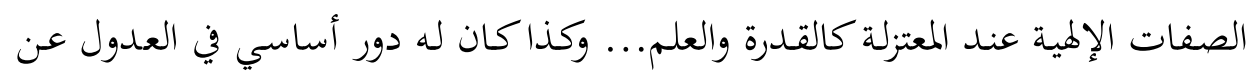

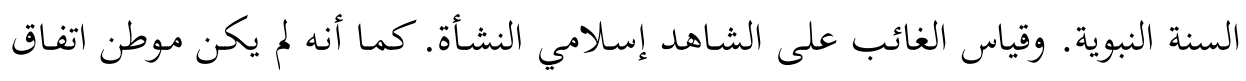

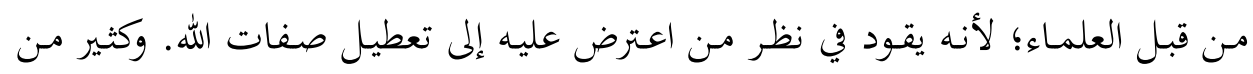

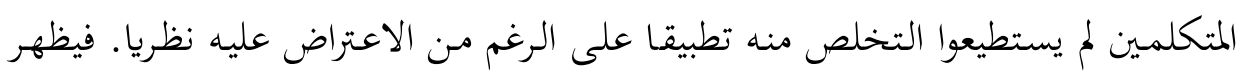

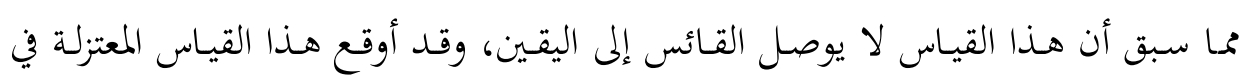
مزالق ومتاهات، وجرهم إلى تشبيه الله بمخلوقاته. 